\title{
LONG-TERM PERFORMANCE MODELLING OF ETOBICOKE EXFILTRATION SYSTEM
}

By

Haiyue Liu

B.Eng, China University of Mining and Technology, 2013

\author{
A Thesis \\ Presented to Ryerson University \\ in partial fulfillment of the requirements for the degree of \\ Master of Applied Science \\ in the Program of \\ Civil Engineering
}

Toronto, Ontario, Canada, 2016

(CHaiyue Liu 2016 


\section{Author's Declaration}

I hereby declare that I am the sole author of this thesis. This is a true copy of the thesis, including any required final revisions, as accepted by my examiners.

I authorize Ryerson University to lend this thesis to other institutions or individuals for the purpose of scholarly research.

I further authorize Ryerson University to reproduce this thesis by photocopying or by other means, in total or in part, at the request of other institutions or individuals for the purpose of scholarly research.

I understand that my thesis may be made electronically available to the public. 


\author{
Abstract \\ Haiyue Liu \\ Master of Applied Science \\ Civil Engineering \\ Ryerson University \\ 2016
}

Long-term Performance Modelling of Etobicoke Exfiltration System

Urbanization increases the stress on the hydrologic cycle. The Etobicoke exfiltration system (EES) was developed in 1993 to remediate the impact on the hydrologic cycle after urbanization. The purpose of this research is to model the Etobicoke exfiltration system (EES) and evaluate the stormwater management performance of EES. A comprehensive literature review was conducted on development of stormwater management and Low impact development (LID). The US EPA SWMM was selected to model the EES. Three modelling methods were investigated to simulate the performance of EES. The Orifice-Storage-Pump method was found to perform the best. EES was applied before an existing wet pond in a case study subdivision. The modelling results show that EES meets three criteria: reduce water quantity, impact water balance and improve water quality. 


\section{Acknowledgements}

I would like to gratefully acknowledge my supervisor Dr. James Li for his guidance, support, and inspiration throughout my master degree. My acknowledgement also extends to Dr. Darko

Joksimovic for his elaborative guidance in my modelling work. My last thanks go to Dr. Matyn Hills for helping me proofread this thesis. 


\section{Dedication}

To my parents for their support and love 


\section{Table of Contents}

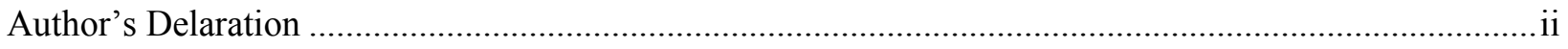

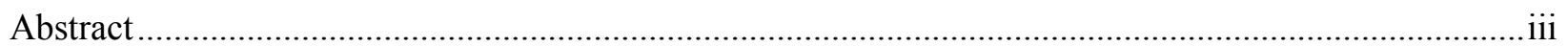

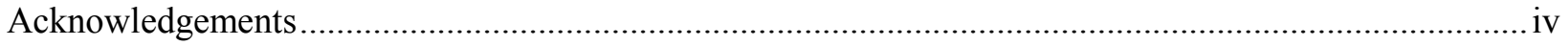

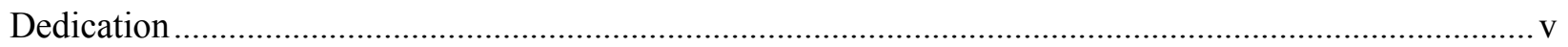

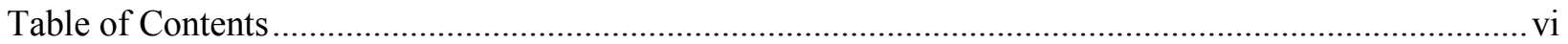

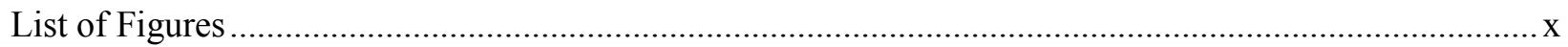

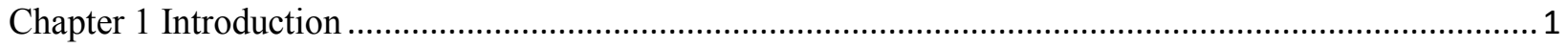

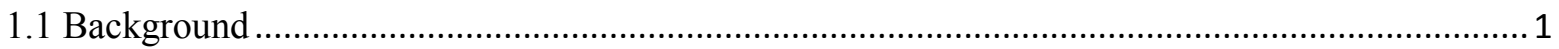

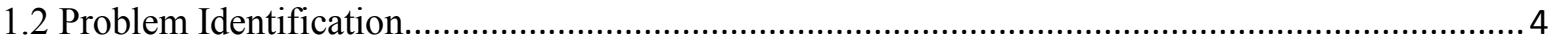

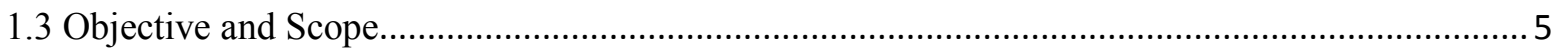

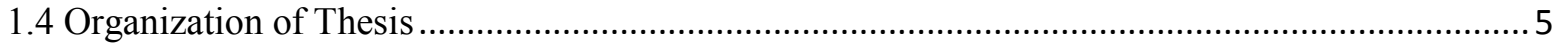

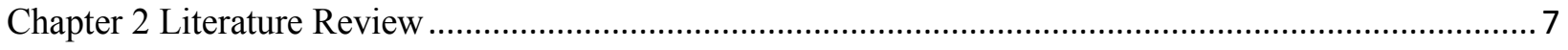

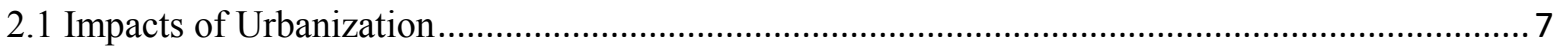

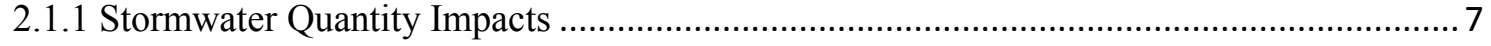

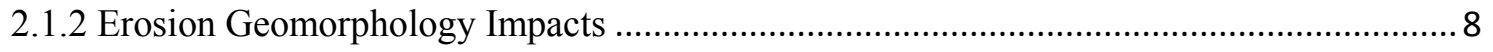

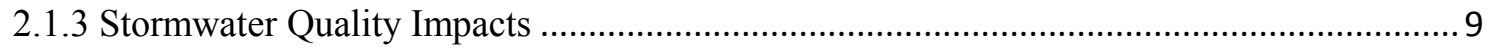

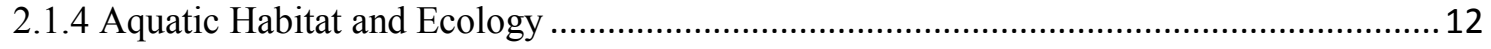

2.2 Evolution of Stormwater Management in Ontario ................................................................. 12

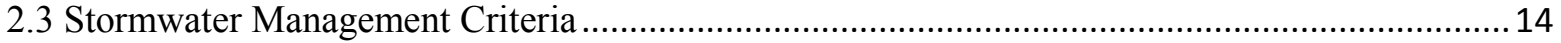

2.4 Stormwater Management Facilities and Low Impact Development Practices............................. 16

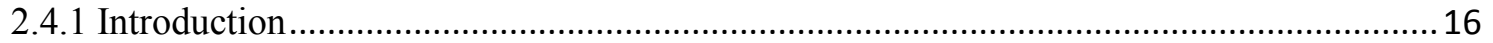

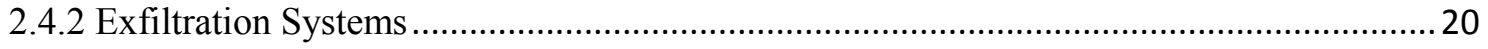

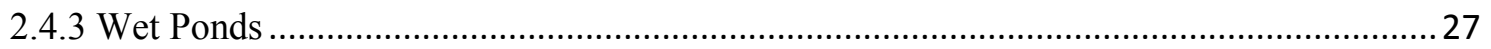

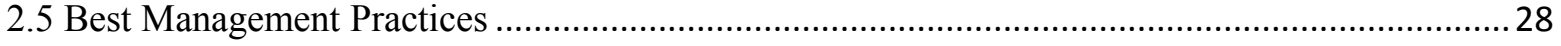

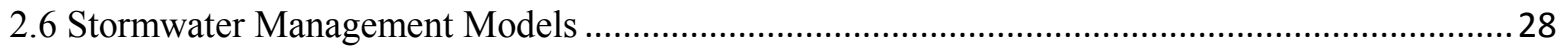

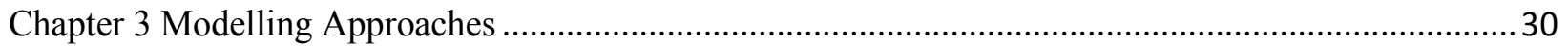

3.1 Etobicoke Exfiltration System (EES) ……....................................................................... 30 


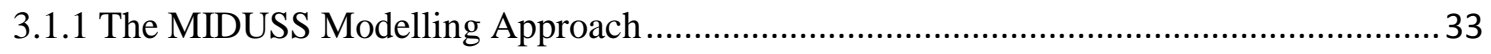

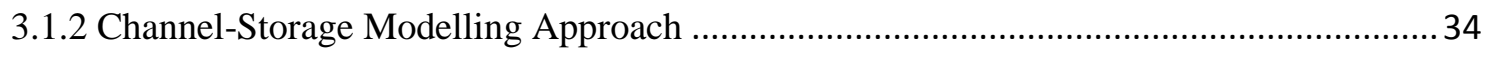

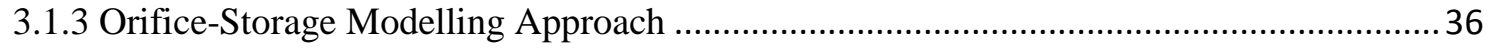

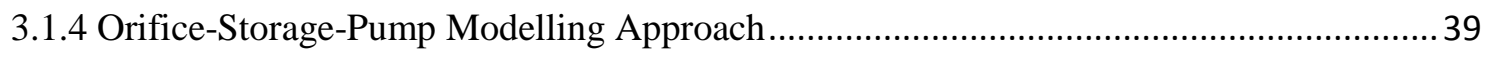

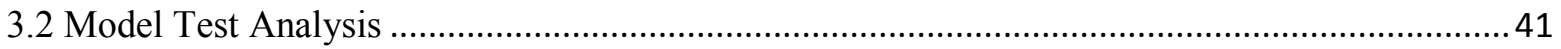

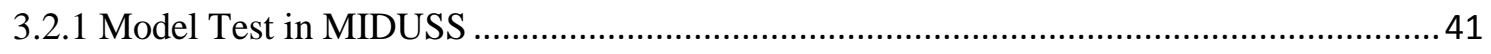

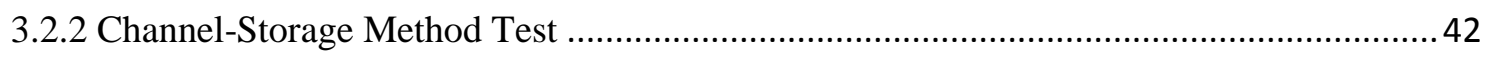

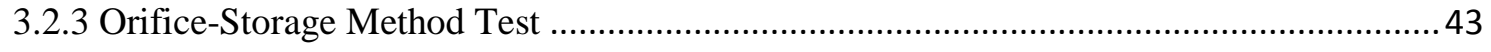

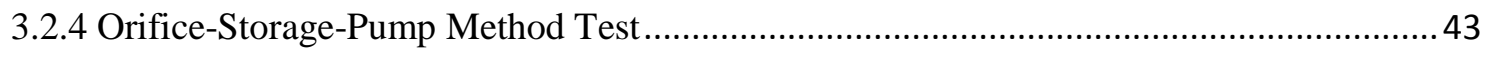

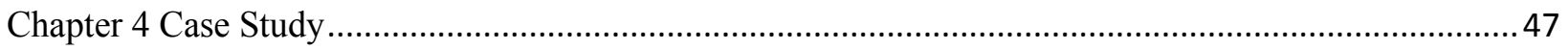

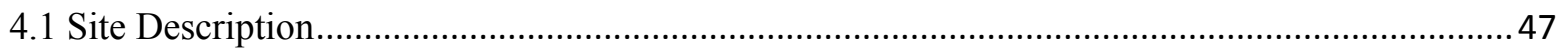

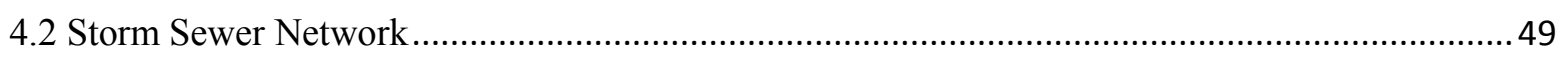

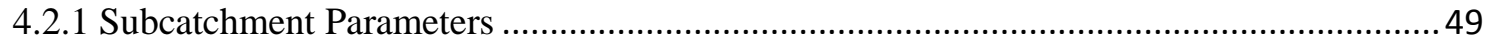

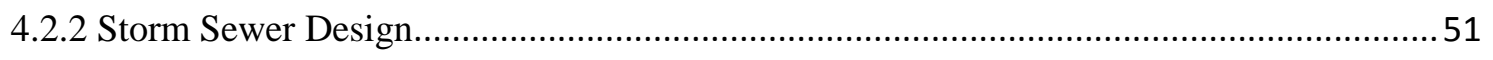

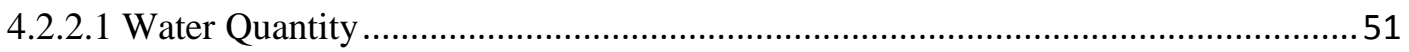

4.2.2.2 Sewer Pipe Capacity ................................................................................... 52

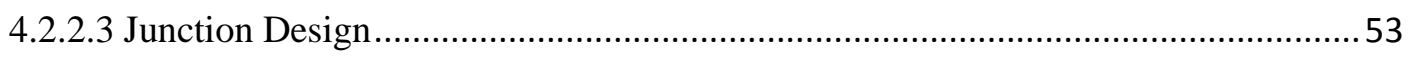

4.2.3 Storm Sewer Network Sensitivity Analysis and Calibration ..........................................53

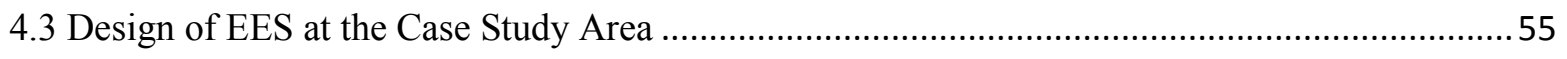

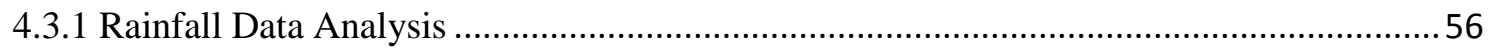

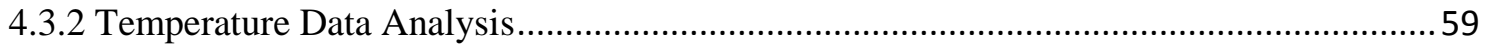

4.4 EES-Wet Pond System Sensitivity Analysis...................................................................... 60

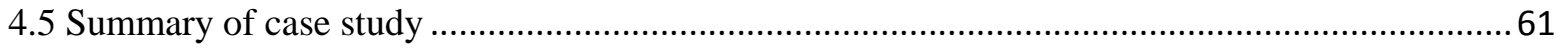

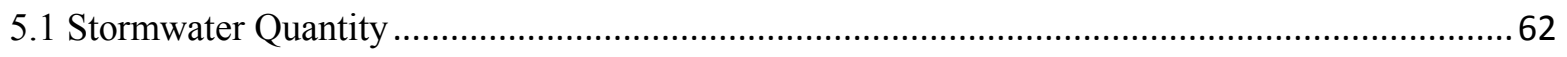

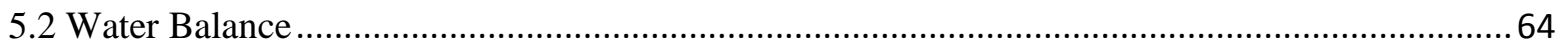

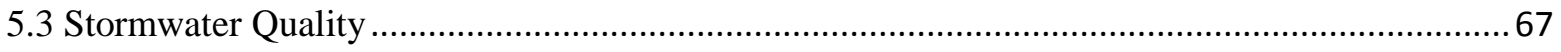

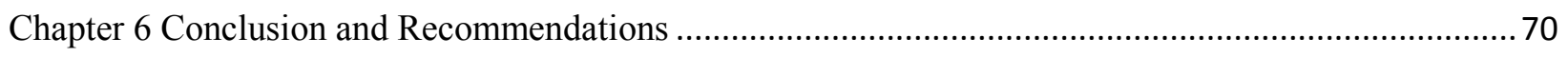

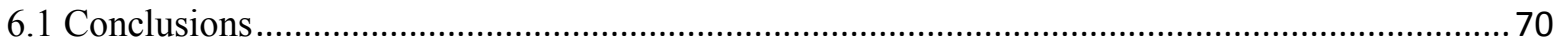

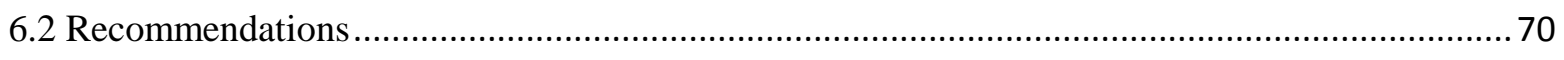




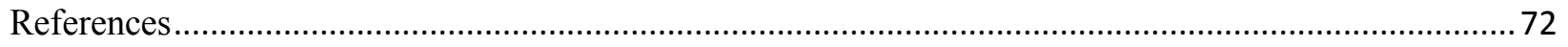

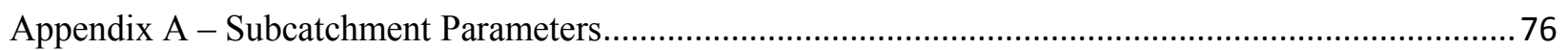

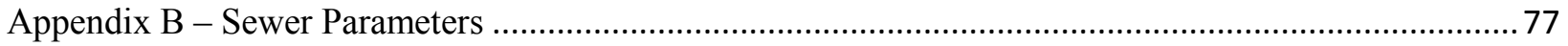

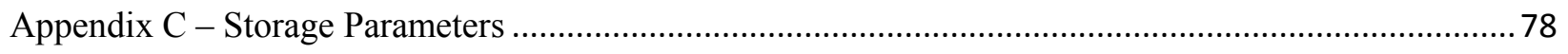

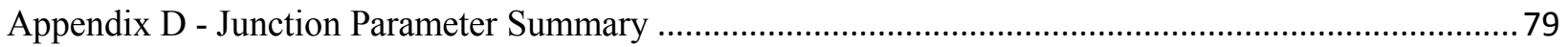

Appendix E - Stormwater Quantity Model: Calibration Charts .......................................................... 80

Appendix F - Rainfall Data-By Descending Total Record Data .......................................................... 82

Appendix G - System Sensitivity Analysis - WetPond Head ................................................................ 84

Appendix H - System Sensitivity Analysis - Wet Pond Inflow and Outflow....................................... 89 


\section{List of Tables}

Table 1 Comparisons of urban stormwater runoff concentrations with provincial water quality objectives

Table 2 Suspended solids removed efficiency of different types of drainage area ................................. 11

Table 3 Nutrient concentration and guidelines at the inlet of stormwater treatment facilities 12

Table 4 Guidelines and manuals corresponding to evolution of stormwater management

Table 5 Water quality storage requirements based on receiving waters (Ministry of Environment (MOE),

2003)

Table 6 Pollutant removal efficiencies for soakaways, infiltration trenches and percentage of perforated pipe systems (Credit Valley Conservation (CVC); Toronto and Region Conservation (TRCA), 2010) .... 21

Table 7 Trench parameters between MH2 and MH3 (Tran \& Li, 2015) ............................................... 32

Table 8 Calibrated catchment parameters ........................................................................................... 33

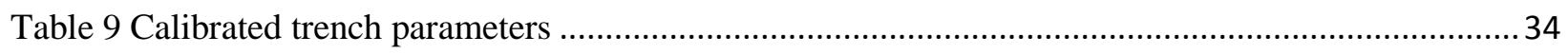

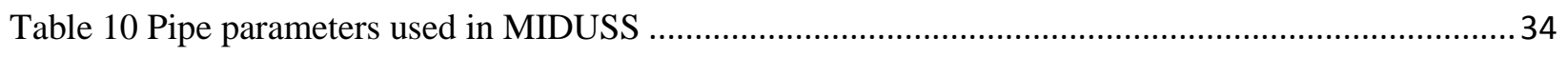

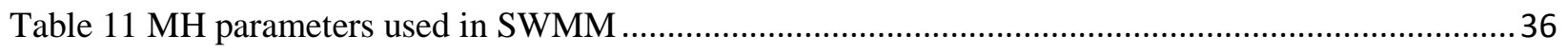

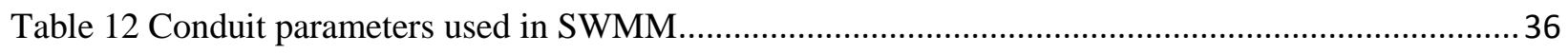

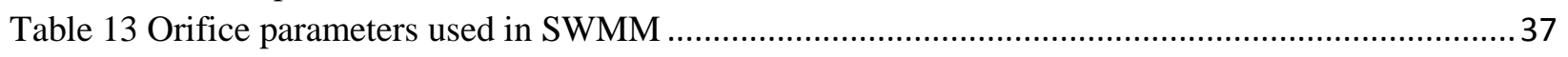

Table 14 Soil characteristics (Rossman, 2008) …........................................................................... 49

Table 15 Pipe size and thickness (Ontario Concrete Pipe Association (OCPA), 1997) ...........................53

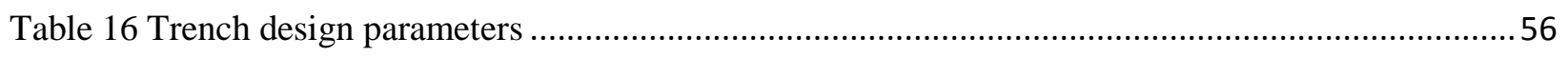

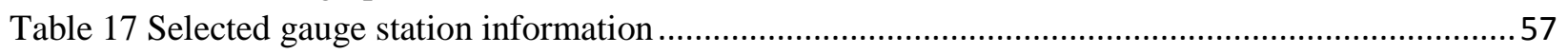

Table 18 Selected gauge station information .................................................................................. 59 


\section{List of Figures}

Figure 1 Relationship between impervious cover and surface runoff (United States Environmental

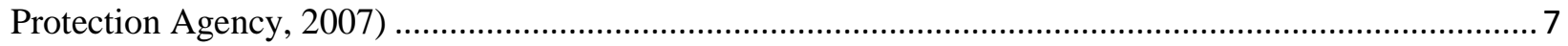

Figure 2 Runoff hydrographs before and after development ........................................................... 8

Figure 3 Cross-section of constructed EES................................................................................. 23

Figure 4 Typical profile of EES (A.M. Candaras Associates Inc., 1997) ................................................24

Figure 5 Rainfall hyetograph of October 5-6, 1995 historic event (A.M. Candaras Associates Inc., 1997)

Figure 6 Measured trench hydraulics of EES for the Oct. 5-6, 1995 historic event .................................. 32

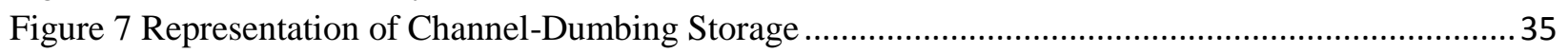

Figure 8 Representation of Orifice-Storage system in SWMM ......................................................... 37

Figure 9 Trench graphic model representations in SWMM................................................................. 38

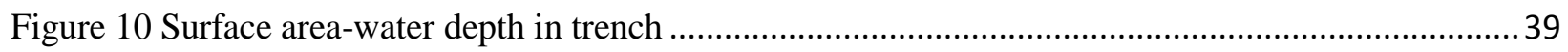

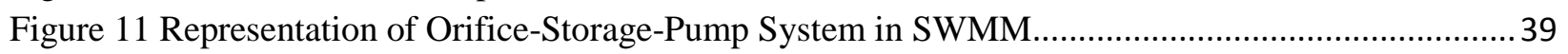

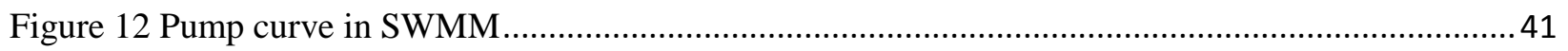

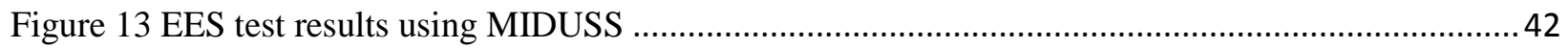

Figure 14 EES simulated results in SWMM for the Oct. 5-6, 1995 historic event................................. 44

Figure 15 EES head results using SWMM ............................................................................... 45

Figure 16 EES $\mathrm{MH}_{2} \mathrm{Head}$ results compared with measured $\mathrm{MH}_{2} \mathrm{Head}$................................................ 45

Figure $17 \mathrm{MH}_{3}$ Head results compared with measured $\mathrm{MH}_{3} \mathrm{Head}$.................................................... 46

Figure 18 Map outlining the location of the subcatchment within the Town of Richmond Hill ............... 47

Figure 19 A satellite picture showing the terrain and drainage area of the subcatchment .........................48

Figure 20 Study area storm sewer network ............................................................................... 50

Figure 21 Head difference - percent change in parameter ............................................................... 54

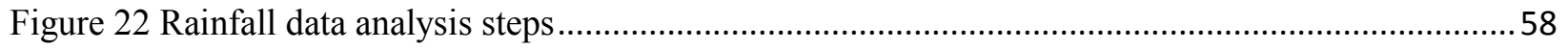

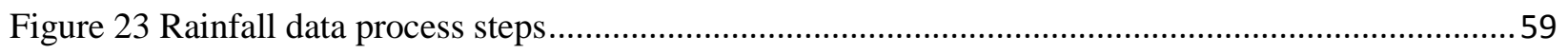

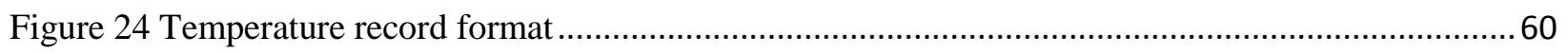

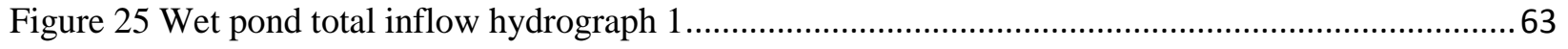

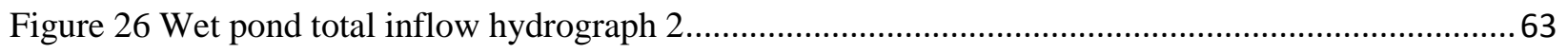

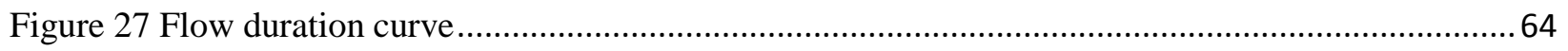

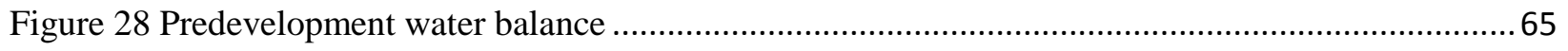

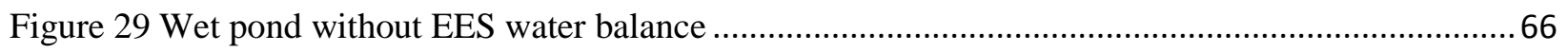

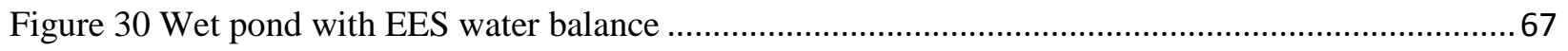

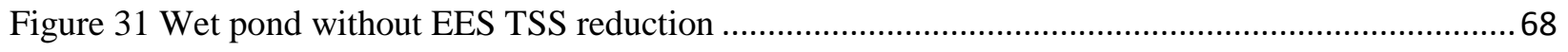

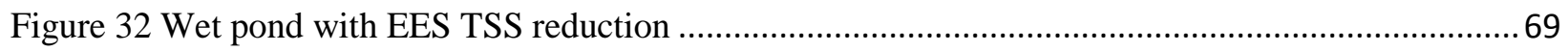

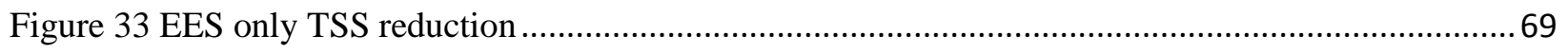




\section{Chapter 1 Introduction}

\subsection{Background}

Urbanization has a drastic impact on the hydrologic cycle, especially on the natural process of stormwater runoff. Compact urban development increases impervious areas inside a city, which impacts the urban runoff in following ways: the runoff volume after development is greater and the peak flow occurs sooner with higher magnitude and shorter duration. Urban intensification also causes runoff related problems with regard to channel instability, impaired habitat, losses of wetlands and so on. As a consequence, urbanization is recognized as an important stressor to stream ecosystems.

According to the Ontario Ministry of Environment (MOE)'s Stormwater Management Planning and Design Manual (2003), stormwater management facilities are categorized as lot level controls, conveyance controls, and end-of-pipe controls. The term "treatment train" was proposed to broader solutions to stormwater management by combining these three types of facilities. By maintaining the natural hydrologic cycle, lot and conveyance controls can reduce the size of end of pipe facilities, which are required for flood and erosion control. (Ministry of Environment (MOE), 2003).

Traditional stormwater management has primarily dealt with water quantity and flood control. However, over the past few years, stormwater management has been considering water quality. As a consequence, Low Impact Development (LID) and Best Management Practices (BMPs) have been developed accordingly.

According to Credit Valley Conservation (CVC), "Low impact development (LID) is a stormwater management strategy that seeks to mitigate the impacts of increased runoff and 
stormwater pollution by managing runoff as close to its source as possible"(Credit Valley Conservation (CVC); Toronto and Region Conservation (TRCA), 2010). LID principles are based on controlling stormwater at the source by the use of micro-scale controls that are distributed throughout the site. The United States Environmental Protection Agency (US EPA) defines LID as: "a set of site design strategies that minimize runoff and distributed, small scale structural practices that mimic natural or predevelopment hydrology through the processes of infiltration, evapotranspiration, harvesting, filtration and detention of water" (United States Environmental Protection Agency, 2007). These practices can effectively remove nutrients, pathogens and metals from surface runoff, as well as reduce stormwater volume and intensity (Credit Valley Conservation (CVC); Toronto and Region Conservation (TRCA), 2010).

The application of LID has both economical as well as environmental benefits. In 2007, the US EPA investigated stormwater costs through 17 LID cases. The report indicates that applying LID can reduce project costs and improve environmental performance (United States Environmental Protection Agency, 2007). LID practices provide opportunities not only to retrofit existing highly urbanized polluted areas but also to address environmental issues in newly developed areas (United States Environmental Protection Agency (US EPA), 2000) LID is currently one of the main tenets of Ontario Ministry of Environment and Climate Change's approaches to stormwater management. In 2015, a bulletin from the Ministry of Environmental and Climate Changes (MOECC) suggested that the stormwater management plans, which had been submitted to the ministry for Environmental Compliance Approval (ECA), did not address preservation of the natural hydrology (Ministry of Environment and Climate Change, 2015). Two steps were proposed to improve the implementation of LID: 
"Clarify the ministry's existing requirements and guidance on stormwater management" and "Produce a LID stormwater management guidance document."

Clearly, the principles for employing LID are outlined in MOECC's related acts, regulations, policies and guidelines. However, the guidance on LID can be improved in many respects such as dealing with inconsistencies in the 2003 Stormwater Management Manual (Ministry of Environment and Climate Change, 2015), and findings from this research can also serve to supplement current LID practices, especially in relation to Etobicoke exfiltration system (EES).

In a manner similar to the concept of LID, Water Sensitive Urban Design (WSUD) has been proposed in Australia, which is an approach to urban planning and design that integrates the management of the total water cycle into the urban development process (Government of South Australia Adelaide, 2009). WSUD includes a pro-active process of recognizing the design opportunities in order to intrinsically link landscape architecture and stormwater management facilities (Wong, 2006). The innovation of stormwater management facilities within an urban environment requires a shift to "at source" stormwater management systems. Stormwater best management practices (BMPs) was proposed to control flood runoff events, which uses a centralized location for stormwater management at the watershed level (Dmodaram, Giacomoni, C. Prakash Khedun, Ryan, Saour, \& Zechman, 2010). "Stormwater Best Management Practices (BMPs) are techniques, measures or structural controls used to manage the quantity and improve the quality of stormwater runoff" (United States Environmental Protection Agency (US EPA), 1999). BMPs can be implemented to achieve a variety of goals depending on the needs of practitioners. Three main goals should be 
considered when applying BMPs: flow control, pollutant removal, and pollutant source reductions (United States Environmental Protection Agency (US EPA), 1999).

\subsection{Problem Identification}

Although LIDs have been successful in pilot trials as an approach to stormwater management, questions have been raised in regard to its suitability for all sites, groundwater contamination, and winter performance (Dietz, 2007). For instance, there have been suggestions made that (1) site conditions, such as soil permeability, slope, and water table depth, should be considered when applying LID; and (2) community perception of LID may prevent its implementation because homeowners want large lots and wide streets (United States Environmental Protection Agency (US EPA), 2000). Moreover, several studies have shown the phosphorus export from bio-retention systems could cause more harm to sensitive downstream water bodies (Dietz, 2007). The total phosphorus export from bioretention systems in Canada has been attributed to leaching of the mulch and organic soil media (Toronto and Region Conservation, 2006). Additionally, Holman-Dodds et al. (2003) have shown that, in general, LID technologies become less effective at higher rainfall.

The Etobicoke exfiltration system (EES) is one type of LID practices designed in 1993 to address stormwater runoff volume over four seasons. During the 20 years' development, EES has been built and monitored in several places in Toronto (A.M. Candaras Associates Inc., 1997)(Stormwater Assessment Monitoring and Perfomance Program, 2004). Although event based performance of EES has already been investigated, there is a lack of research focusing on the prediction of long-term performance of EES in terms of water quantity, water balance and water quality. 


\subsection{Objective and Scope}

This objective of this research thesis is to develop a modelling approach to predict the longterm hydrologic performance of Etobicoke exfiltration system (EES). Using a development site in the Town of Richmond Hill and the US EPA Storm Water Management Model (SWMM), the hydrologic and water quality effect of EES were determined with and without a downstream wet pond. The research focuses on the following investigations:

- Apply the EES to a storm sewer network at the site and assess the performance of EES in terms of stormwater runoff volume and peak flow reduction;

- Assess the impact of the EES on wet pond total suspended solids (TSS) removal efficiency;

- Compare the pre-development and post-development (wet pond only; wet pond with EES; EES only) water balance at the development site.

\subsection{Organization of Thesis}

This thesis consists of six chapters. Chapter 1 provides the background of this research, problems definition as well as objective and scopes. Chapter 2reviews relevant literature, including urbanization impacts, evolution of stormwater management in Ontario, stormwater management criteria development, stormwater management facilities, low impact development practices, best management practices, and stormwater management models. Chapter 3 introduces the research methodology, including different methods of modelling EES. Chapter 4 is the case study consisting of stormwater network in the study area, and methods of data collection and application of the EES modelling methodology. Results of the 
study are given in Chapter 5, while Chapter 6 provides a conclusion and makes recommendations for future related research. 


\section{Chapter 2 Literature Review}

\subsection{Impacts of Urbanization}

\subsubsection{Stormwater Quantity Impacts}

Urban development replaces vegetation with impervious surface such as roads, driveways, parking areas, and building roofs, thus decreasing infiltration and evapotranspiration. As shown in Figure1, the introduction of hard surfaces and reduction in vegetated cover impacts the hydrologic circle (The Municipal Infrastructure Group Ltd.; Schollen \& Company Inc., 2011).
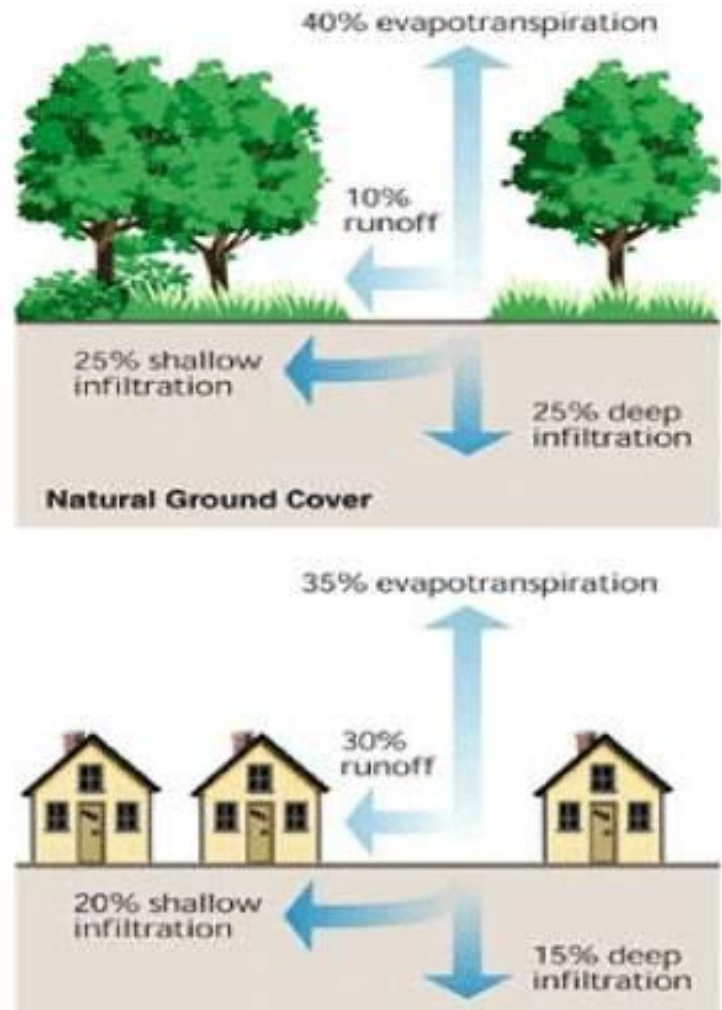

$35 \%-50 \%$ Impervious Surface
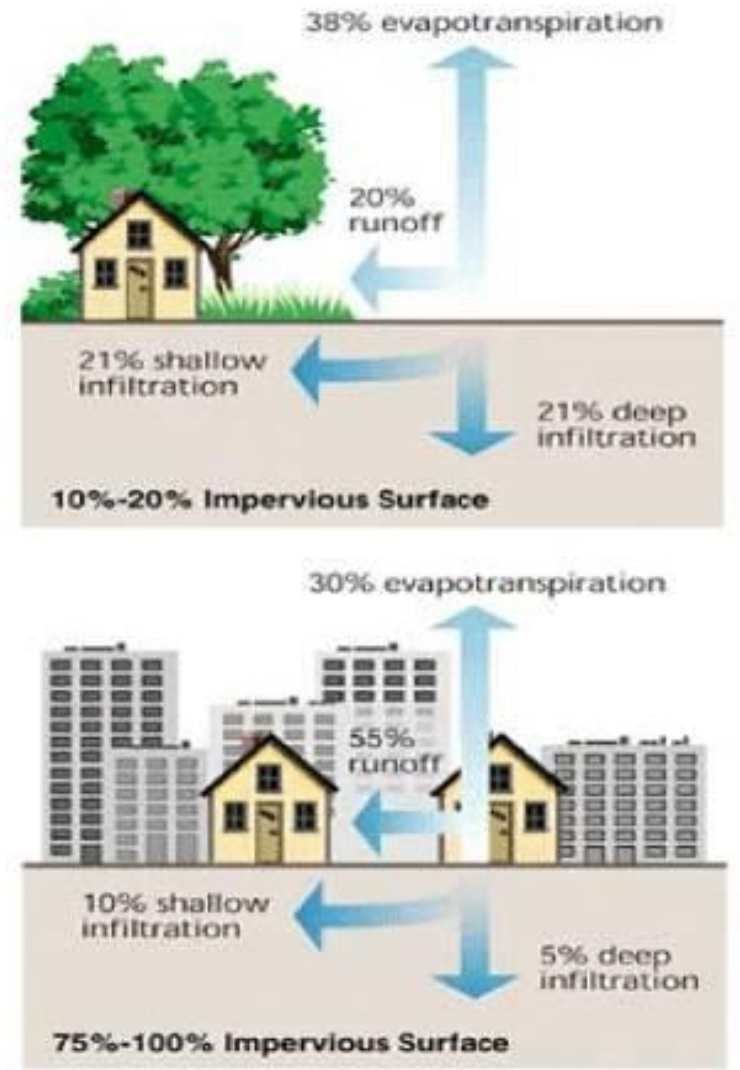

Figure 1 Relationship between impervious cover and surface runoff (United States

Environmental Protection Agency, 2007) 
As such, urbanization will increase runoff rate and volume, as well as produce sooner peak flow with higher magnitude and shorter duration as shown in Figure 2. At the same time, the duration of a storm event is shorter after development. These higher peak flows, larger volumes and higher velocity will increase the flood frequency and magnitude. Therefore, a one-year storm peak flow will no longer occur once a year. For instance, at a watershed with $30 \%$ imperviousness, events which used to occur once a year (or two years) may occur 3.3 to 10.6 times a year (or two years)(Hollis, 1975).

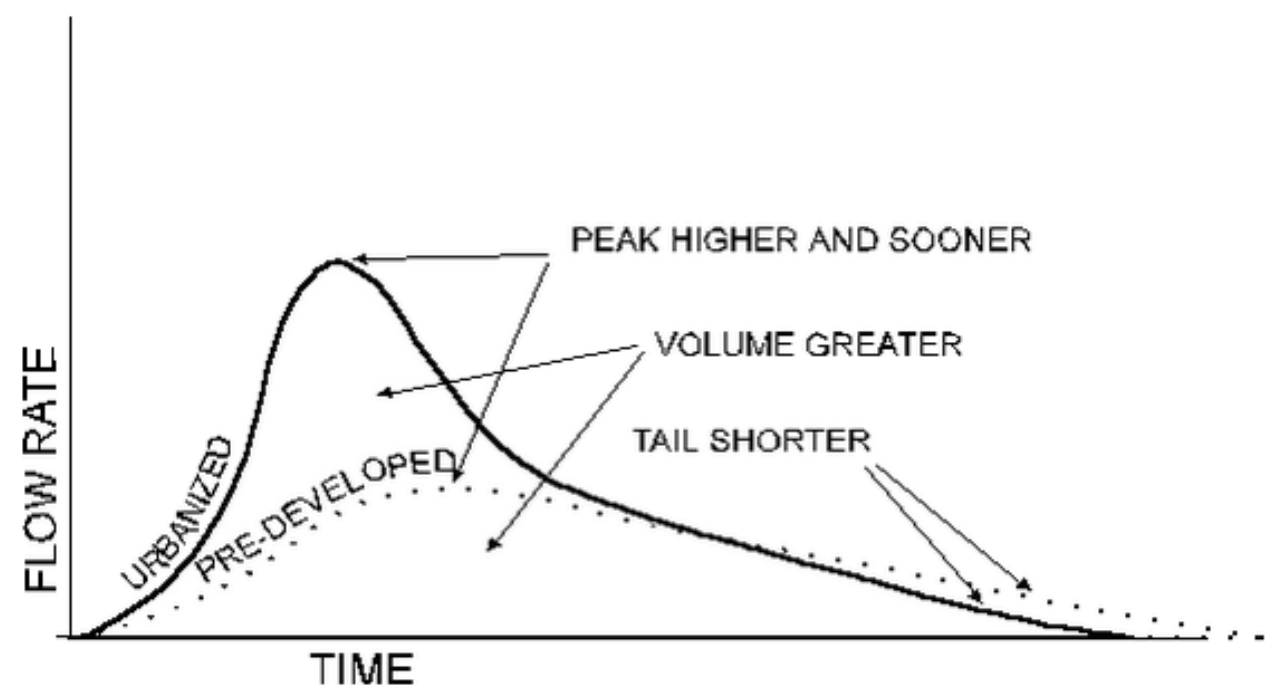

Figure 2 Runoff hydrographs before and after development

(Source: http://www.civil.ryerson.ca/Stormwater/menu1/index.htm)

\subsubsection{Erosion Geomorphology Impacts}

The above hydrological alterations accelerate erosion resulting in unstable stream channels and physical changes to accommodate higher flows (Bradford \& Gharabaghi, 2004). The larger amount of stormwater runoff caused by urbanization makes channels wider and straighter from bank erosion (United States Environmental Protection Agency (US EPA), 
1999). Additionally, because of in stream erosion and watershed inputs, sediment loads in streams will increase and streambeds will be modified (Ministry of Environment (MOE), 2003).

\subsubsection{Stormwater Quality Impacts}

Urbanization has given rise to stormwater pollution problems since the latter part of the last century. In a 1998 Report to Congress, the US EPA stated that urban stormwater runoff is the fourth most extensive cause of water quality impairment of the nation's rivers, and the third most extensive source of water quality impairment of lakes (US EPA, 1990; Novotny \&Olem, 1994). Pollution in runoff can come from both atmospheric and non-atmospheric sources (Tsihrintzis \& Hamid, 1997). The runoff stormwater picks up pesticides, road salts, heavy metals, oils, bacteria, and other harmful pollutants and transports them through municipal sewers into streams, rivers and lakes (Toronto and Region Conservation, 2012). Moreover, biological communities are affected by hydrological alterations, stream form, temperature regime, and water and sediment quality as well (Bradford \& Gharabaghi, 2004). Table 1 shows a comparison of selected constituent concentrations and Ontario's Provincial Water Quality Objectives (Ministry of Environment (MOE), 2003). 
Table 1 Comparisons of urban stormwater runoff concentrations with provincial water quality objectives

\begin{tabular}{|l|c|c|c|}
\hline Parameter & Units & PWQO & Observed Concentrations \\
\hline Fecal coliforms & $\mathrm{CNT} / \mathrm{dL}$ & - & $10,000-16 \mathrm{E} 6$ \\
\hline $\mathrm{SS}$ & $\mathrm{mg} / \mathrm{L}$ & - & $87-188$ \\
\hline $\mathrm{TP}$ & $\mathrm{mg} / \mathrm{L}$ & 0.03 & $0.3-0.7$ \\
\hline $\mathrm{TKN}$ & $\mathrm{mg} / \mathrm{L}$ & - & $1.9-3$ \\
\hline $\mathrm{Phenolics}$ & $\mathrm{mg} / \mathrm{L}$ & 0.001 & $0.014-0.019$ \\
\hline $\mathrm{Al}$ & $\mathrm{mg} / \mathrm{L}$ & - & $1.2-2.5$ \\
\hline $\mathrm{Fe}$ & $\mathrm{mg} / \mathrm{L}$ & - & $2.7-7.2$ \\
\hline $\mathrm{Pb}$ & $\mathrm{mg} / \mathrm{L}$ & 0.025 & $0.038-0.055$ \\
\hline $\mathrm{Ag}$ & $\mathrm{mg} / \mathrm{L}$ & 0.0001 & $0.002-0.005$ \\
\hline $\mathrm{Cu}$ & $\mathrm{mg} / \mathrm{L}$ & 0.005 & $0.045-0.46$ \\
\hline $\mathrm{Ni}$ & $\mathrm{mg} / \mathrm{L}$ & 0.025 & $0.009-0.016$ \\
\hline $\mathrm{Zn}$ & $\mathrm{mg} / \mathrm{L}$ & 0.030 & $0.14-0.26$ \\
\hline $\mathrm{Cd}$ & $\mathrm{mg} / \mathrm{L}$ & 0.0002 & $0.001-0.024$ \\
\hline
\end{tabular}

Among all the stormwater pollution elements, sediments and nutrients are considered as main factors.

\section{$\underline{\text { Sediment }}$}

Urban development causes erosion and sediment from upland construction. The washing off of accumulated deposits from impervious areas during storms becomes the dominant source of contaminants (Ministry of Environment (MOE), 2003). Studies have shown that data of sediment in stormwater runoff varies a lot according to the type of land use (Chmakova, 2007). Table 2 shows data of concentrations in different types of land use from a study by Mayer et al. (1995). The table also shows that the average suspended solids removal efficiency depends on the type of drainage area. Olding et al. (2004) conducted a study on the 
Richmond Hill ponds, showing that while TSS can be fairly high (around $908 \mathrm{mg} / \mathrm{L}$ ), $75 \%$ of TSS concentrations are below $60 \mathrm{mg} / \mathrm{L}$.

Table 2 Suspended solids removed efficiency of different types of drainage area

\begin{tabular}{|c|c|c|}
\hline Type of land use & $\begin{array}{c}\text { Concentration in } \\
\text { Stormwater runoff } \\
(\mathbf{m g} / \mathbf{L})\end{array}$ & $\begin{array}{c}\text { Removal efficiency } \\
\text { of ponds }(\%)\end{array}$ \\
\hline Residential area & $5-267$ & 24 \\
\hline Industrial area & $8.8-119$ & 25 \\
\hline Open area & $0.5-66.8$ & 0 \\
\hline
\end{tabular}

Elevated levels of suspended solids, including organic and inorganic matter, have several effects on water quality (Ministry of Environment (MOE), 2003):

- Increased turbidity reduced light penetration;

- Suspension clog gills and interfere with fish feeding;

- Sediment covers spawning areas and smother benthic communities; and

- Organic matter depresses the levels of dissolved oxygen.

\section{Nutrients}

Traditionally, nutrients are thought to be a major pollutant in agricultural runoff. However, fertilizer application on lawns, golf courses and municipal recreation parks also cause pollution. High concentrations of nutrients after urbanization can easily cause dissolved oxygen depletion, ammonia and nitrate toxicity, and eutrophication. Several studies have found nutrient concentration at the inlet of stormwater treatment facilities, as shown in Table 3. Although Mayer et al. (1995) contended that removal efficiency is very limited; other studies have found that facilities with vegetation, especially macrophyte, could increase the removal efficiency of nutrients (Groffman \& Crawford, 2003). 
Table 3 Nutrient concentration and guidelines at the inlet of stormwater treatment facilities

\begin{tabular}{|c|c|c|}
\hline Type of nutrient & $\begin{array}{c}\text { Concentration so at the inlet of SWM } \\
\text { facilities }\end{array}$ & Guidelines \\
\hline Nitrate nitrogen & $\begin{array}{c}0.203-1.6 \mathrm{mg} / \mathrm{L} \text { (Mayer, Marsalek, \& Reyes, } \\
1995) ; 0.2-1.3 \mathrm{mg} / \mathrm{L} \text { (Mallin et al., 1992) }\end{array}$ & $\begin{array}{c}<10 \mathrm{mg} / \mathrm{L} \text { (Environmental } \\
\text { Canada, 1984) }\end{array}$ \\
\hline $\begin{array}{c}\text { Ammonia } \\
\text { nitrogen }\end{array}$ & $\begin{array}{c}0.013-1.082 \mathrm{mg} / \mathrm{L} \text { (Mayer, Marsalek, \& } \\
\text { Reyes, 1995); 0.1-0.2mg/L (Stanley, 1996) }\end{array}$ & $\begin{array}{c}<0.5 \mathrm{mg} / \mathrm{L} \text { (Environmental } \\
\text { Canada, 1994) }\end{array}$ \\
\hline $\begin{array}{c}\text { Phosphate } \\
\text { phosphorus }\end{array}$ & $\begin{array}{c}\text { Excellent, if }<0.1 \mathrm{mg} / \mathrm{L} \\
\text { Center of Earth and } \\
\text { Environmental Science, } \\
\text { 2005) }\end{array}$ \\
\hline
\end{tabular}

\subsubsection{Aquatic Habitat and Ecology}

Urbanization has negatively affected the aquatic habitat. Reduced baseflow, flow depth and velocity, and poor water quality has impacted the aquatic habitat in the following ways:

- Reduced the size of suitable aquatic habitat;

- Influenced the aquatic species distribution within a stream;

- Restricted fish spawning areas;

- Decreased fish health, reproduction, feeding and diversity;

- Decreased benthic macro invertebrates diversity; and

- Caused excessive algae and eutrophication.

\subsection{Evolution of Stormwater Management in Ontario}

In order to reduce the impacts of urbanization, stormwater management was required to manage runoff quantity and quality (The Municipal Infrastructure Group Ltd.; Schollen \& Company Inc., 2011). Stormwater management in Ontario originally focused on runoff volume and peak flow control for the purpose of flood control, and only minor systems were 
considered within stormwater management. However, after several years of development a major system was introduced to reduce the size of the minor systems (Watt et al., 2003). In the early 1990s, erosion and sediment loading as a result of urbanization became a concern. Additionally, stormwater management was incorporated into urban development with respect to land use and environmental effects (Ministry of Environment (MOE), 2003). By the end of the 1990s, the Low Impact Development Stormwater Management Planning and Design Guide proposed that stormwater management should focus on four aspects: water quality, erosion control, aquatic habitat, and baseflow maintenance (Credit Valley Conservation (CVC); Toronto and Region Conservation (TRCA), 2010). The Stormwater Management Planning and Practices Manual (2003) proposed by Ontario's Ministry of Environment introduced some current stormwater management technologies. In 2007, stormwater management was required by the Environmental Bill of Rights to take account of the impacts of climate change. Stormwater management developments in the past few years include not only climate change, but also low impact development and water budget (Credit Valley Conservation (CVC); Toronto and Region Conservation (TRCA), 2010). Table 4 indicates guidelines and manuals corresponding to stormwater management evolution, which provide the standards for stormwater management (Ternier, 2012). However, these guidelines restrict opportunities to gain experience and become more innovative (Bradford \& Gharabaghi, 2004). 
Table 4 Guidelines and manuals corresponding to evolution of stormwater management

\begin{tabular}{|c|c|}
\hline Authority & Guidelines and Manuals \\
\hline Ministry of Natural Resources, 1987 & $\begin{array}{c}\text { Guidelines on Erosion and Sediment Control } \\
\text { for Urban Construction Sites }\end{array}$ \\
\hline $\begin{array}{c}\text { Ministry of Environment and Ministry } \\
\text { of Natural Resources, 1991 }\end{array}$ & $\begin{array}{c}\text { Interim Stormwater Quality Control } \\
\text { Guidelines for New Development }\end{array}$ \\
\hline $\begin{array}{c}\text { Ministry of Environment and Ministry } \\
\text { of Natural Resources, 1993 }\end{array}$ & $\begin{array}{c}\text { Water Management on a Watershed Basis: } \\
\text { Implementing an Ecosystem Approach }\end{array}$ \\
\hline $\begin{array}{c}\text { Ministry of Environment and Ministry } \\
\text { of Natural Resources, 1993 }\end{array}$ & Sub watershed planning \\
\hline $\begin{array}{c}\text { Ministry of Environment and Ministry } \\
\text { of Natural Resources, 1993 }\end{array}$ & $\begin{array}{c}\text { Integrating Water Management Objectives } \\
\text { into Municipal Planning Document }\end{array}$ \\
\hline Ministry of Environment, 1994 & $\begin{array}{c}\text { 1994 Stormwater Management Planning and } \\
\text { Practices Manual }\end{array}$ \\
\hline Ministry of Environment, 2003 & $\begin{array}{c}\text { Stormwater Management Planning and } \\
\text { Practices Manual }\end{array}$ \\
\hline
\end{tabular}

\subsection{Stormwater Management Criteria}

With the development of stormwater management, design criteria have been developed to consider interactions and cumulative effects (Ministry of Environment (MOE), 2003), and to provide guidance on how to improve stormwater management practices (Bradford \& Gharabaghi, 2004). In 2003, Ontario's Ministry of Environment updated its 1994 version of the Planning and Design Manual to include four main objectives of the stormwater management design criteria: water quantity, water balance, water quality, and erosion control. As runoff volume and peak flow increased with urban development, the criteria required that the maximum peak flow should be within 2 to 100 years storms, which is the predevelopment levels (Bradford \& Gharabaghi, 2004). With regard to channel protection, geomorphic thresholds for channel stability and requirements for habitat protection are taken into consideration in the design criteria (Bradford \& Gharabaghi, 2004). Although significant improvements have been identified in the design criteria, refinements to channel protection 
are still needed. The volumetric quality criteria are estimated using the SWMM model flow prediction and a "Pond" sedimentation model (Bradford \& Gharabaghi, 2004). There are three levels of pond water quality protection: enhanced protection, normal protection, and basic protection. Table 5 presents the volumetric water quality criteria (Ministry of Environment (MOE), 2003). The criteria also take nutrients, bacteria and temperature into consideration. Ontario's Ministry of Environment uses this model to determine groundwater recharge as well. However, as some data cannot support this model's approach, calculating an annual recharge volume requirement is used instead (Bradford \& Gharabaghi, 2004).

Table 5 Water quality storage requirements based on receiving waters (Ministry of Environment (MOE), 2003)

\begin{tabular}{|c|c|c|c|c|c|}
\hline \multirow[b]{2}{*}{ Protection Level } & \multirow[b]{2}{*}{ SWMP Type } & \multicolumn{4}{|c|}{$\begin{array}{l}\text { Storage Volume }\left(\mathrm{m}^{3} / \mathrm{ha}\right) \text { for } \\
\text { Impervious Level }\end{array}$} \\
\hline & & $35 \%$ & $55 \%$ & $70 \%$ & $85 \%$ \\
\hline \multirow{4}{*}{$\begin{array}{l}\text { Enhanced } \\
80 \% \text { long-term } \\
\text { S.S. removal }\end{array}$} & Infiltration & 25 & 30 & 35 & 40 \\
\hline & Wetlands & 80 & 105 & 120 & 140 \\
\hline & Hybrid Wet Pond/Wetland & 110 & 150 & 175 & 195 \\
\hline & Wet Pond & 140 & 190 & 225 & 250 \\
\hline \multirow{4}{*}{$\begin{array}{l}\text { Normal } \\
70 \% \text { long-term } \\
\text { S.S. removal }\end{array}$} & Infiltration & 20 & 20 & 25 & 30 \\
\hline & Wetlands & 60 & 70 & 80 & 90 \\
\hline & Hybrid Wet Pond/Wetland & 75 & 90 & 105 & 120 \\
\hline & Wet Pond & 90 & 110 & 130 & 150 \\
\hline \multirow{5}{*}{$\begin{array}{l}\text { Basic } \\
60 \% \text { long-term } \\
\text { S.S. removal }\end{array}$} & Infiltration & 20 & 20 & 20 & 20 \\
\hline & Wetlands & 60 & 60 & 60 & 60 \\
\hline & Hybrid Wet Pond/Wetland & 60 & 70 & 75 & 80 \\
\hline & Wet Pond & 60 & 75 & 85 & 95 \\
\hline & Dry Pond (Continuous Flow) & 90 & 150 & 200 & 240 \\
\hline
\end{tabular}




\subsection{Stormwater Management Facilities and Low Impact Development Practices}

\subsubsection{Introduction}

LID is the current evolution in stormwater management (The Municipal Infrastructure Group Ltd.; Schollen \& Company Inc., 2011). The main objectives of LID practices are to: maximize infiltration, maximize evapotranspiration, maximize reuse and minimize hard surfaces.

In this section, several stormwater management facilities and LID practices are introduced.

\section{Green roofs}

"Green roofs", also known as "living roofs" or "rooftop gardens", consist of a thin layer of vegetation and growing medium installed on top of a conventional flat or sloped roof (Credit Valley Conservation (CVC); Toronto and Region Conservation (TRCA), 2010). Green roofs can benefit cities as they improve energy efficiency, reduce urban heat island effects, and create green space for passive recreation or aesthetic enjoyment. There are two types of green roofs, one type is intensive green roof with a $15 \mathrm{~cm}$ depth of growing medium and the other is extensive green roof with a $15 \mathrm{~cm}$ or less depth of growing medium. The construction of green roofs should take structural requirements, roof slope and drainage area and runoff volume into consideration (Credit Valley Conservation (CVC); Toronto and Region Conservation (TRCA), 2010). Green roofs are especially effective in older urban areas with chronic combined sewer overflow (CSO) problems, due to the high level of imperviousness (United States Environmental Protection Agency (US EPA), 2000). Applying extensive green roofs in Europe has extended the life of roofs, reduced energy costs and conserved valuable land. Research in Germany showed that the 3 inch design offers the highest benefit to cost ratio (United States Environmental Protection Agency (US EPA), 2000). 


\section{Grass swales}

"Enhanced grass swales are vegetated open channels designed to convey, treat and attenuate stormwater runoff (are also referred to as enhanced vegetated swales)" (Credit Valley Conservation (CVC); Toronto and Region Conservation (TRCA), 2010). Grass swales or channels are often located adjacent to roads and sidewalks, are adaptable to a variety of site conditions, are flexible in design and layout, and are relatively inexpensive (US Department of Transportation). Grass swales can be used to reduce runoff velocity by holding the water until it infiltrates the soil, or directs it to another infiltrating area. Sedimentation, infiltration and adsorption works together to reduce water pollutants. During construction, decreasing the slope or providing dense cover should be considered to reduce the erosion of soils (United States Environmental Protection Agency (US EPA), 2000).

\section{Permeable pavements}

"Permeable pavements, also known as porous pavement, an alternative to traditional impervious pavement, allow stormwater to drain through them and into a stone reservoir where it is infiltrated into the underlying native soil or temporarily detained" (Credit Valley Conservation (CVC); Toronto and Region Conservation (TRCA), 2010). The system can be categorized as full infiltration, partial infiltration, and partial infiltration with flow restrictor. Porous pavements are best suited for low traffic areas, such as parking lots and sidewalks. The most successful installations of alternative pavements are found in coastal areas with sandy soils and flatter slopes (Center for Watershed Protection, 1998). At the end of the twentieth century the cost of paving blocks and stones in Maryland, USA, ranged from US $\$ 2$ to US\$4, whereas asphalt cost US\$0.50 to US\$1 (Center for Watershed Protection, 1998).

\section{Infiltration trenches}


Infiltration trenches, also known as infiltration galleries or linear soakaways, refer to infiltration systems with a subsurface storage component that treat stormwater runoff from several lots as opposed to soakaways pits that are primarily used for a single lot application. "Infiltration trenches are rectangular trenches lined with geotextile fabric and filled with clean granular stone or other void forming material" (Credit Valley Conservation (CVC); Toronto and Region Conservation (TRCA), 2010). Infiltration trenches can hold water in the spaces between stones and excess water soaking into the ground will flow to another overflow area or system, and they can be implemented at the ground surface to intercept overland flows, or underground as part of a storm sewer system (Ministry of Environment (MOE), 2003). The acceptability of infiltration trenches should be confirmed because of potential concerns for aquifer contamination. In most cases, infiltration trenches will provide marginal flooding and erosion control benefits because they are sized for recharge and water quality (Ministry of Environment (MOE), 2003).

\section{$\underline{\text { Bio-retention systems }}$}

Bio-retention systems consist of a topping layer of hard wood mulch, a vegetative layer and a porous media layer. The depression area can hold water with the plants and shrubs growing to increase water tolerance. Water flows into the bio-retention area by means of swales, curb openings or pipes. Accordingly, the bio-retention system are categorized as without an underdrain for full infiltration, with an underdrain for partial infiltration, or with an impermeable liner and underdrain for filtration only, which can also be referred to as a biofilter (Credit Valley Conservation (CVC); Toronto and Region Conservation (TRCA), 2010). Bio-retention systems perform well for the attenuation of stormwater runoff, as well as in removal of pollutants. Microbes presenting in the bio-retention system break down organic 
compounds, which are then killed by the pathogens exposed to sunlight. The pollutants are removed by infiltrating stormwater through the riparian buffers. The suspended solid (SS) will settle at the bottom of the bio-retention system where the stormwater enters into the bioretention system. Vegetation aids in sedimentation by removing TSS, litter, and debris and nutrients attached to the sediment particles (United States Environmental Protection Agency (US EPA), 2000). The application of fertilizer in watershed or directly used in the bioretention cell will introduce the presence of nutrients, such as phosphate and nitrate. There are experiments showing that phosphate existing in stormwater perform the function of removing metal in the bio-retention system due to the potential of phosphate of immobilizing divalent heavy metals from wastewater, solid waste, and contaminated soils (Ma et al., 2002). Other sources estimated the costs for developing bio-retention sites at between US\$3 and US\$15 per square foot of bio-retention area (US EPA, 2000). According to design guidelines, bio-retention systems occupy 5-7\% of the drainage system and have many economic benefits. At the same time, storm sewers can be reduced with a bio-retention system. For example, bio-retention practices reduced the amount of storm drain pipes at a medical office building in Prince George's County, Maryland, USA, from 800 to 230 feet, which resulted in a cost savings of US\$24,000 or $50 \%$ of the overall drainage cost for the site (Department of Environmental Resources, 1993). Maintenance of bio-retention systems is required annually including plant material, soil layer and mulch layer. Plants will provide enhanced environmental benefits over time as root systems and leaf canopies increase in size and pollutant uptake and removal efficiencies (United States Environmental Protection Agency (US EPA), 2000). Soil will lose the ability of filtering pollutant over time (United States Environmental Protection Agency (US EPA), 2000). 


\section{Combined LID practices}

Damodaram et al. (2010) conducted research to simulate the combined BMPs and LID practices using combination systems of rain harvesting system and permeable pavements, which perform better at reducing peak flow than the single rain harvesting system or permeable pavements scenarios. Villarreal et al. (2004) presented an overview of a new open stormwater system of BMPs in series ranging from green-roofs to stormwater ponds and open channels installed in the inner city suburb of Augustenborg in Malmo, southern Sweden. Investigation of the water balance from 2001 to 2002 found that green-roofs had the effect of reducing total runoff and that the ponds successfully attenuate storm peak flows for even a 10-year rainfall. Brown et al. (2012) compared the performance of pervious concrete with subsurface storage in series with bio-retention system (PC-B) with individual LID practices (bioretention). The results showed that hydrologic performance was significantly improved. The PC-B system had treated additional 10\% of annual runoff volume, discharged about half as much outflow volume, and lowered peak outflow rates (Brown, 2012). However as to the water quality, only TSS and TAN (Total ammoniacal nitrogen) concentrations were significantly reduced (Brown, Line, \& Hunt, 2012). The city of Portland in Oregon, USA, has a Green Streets program that combines rain gardens and permeable pavements, green roofs and sidewalks swales. The city estimates to reduce the peak flows by as much as $85 \%$, stormwater volume by 60\%, and water pollution by up to $90 \%$ (Pazwash, 2011).

\subsubsection{Exfiltration Systems}

In this research, an Etobicoke exfiltration system is used as a LID to improve the effectiveness of a wet pond. Exfiltration systems are also known as perforated pipe systems, pervious pipe systems, clean water collector systems, and percolation drainage systems. 
Exfiltration Systems can be used in place of conventional storm sewer pipes, where topography, water table depth, and runoff quality conditions are suitable (Credit Valley Conservation (CVC); Toronto and Region Conservation (TRCA), 2010). Several studies of exfiltration systems in Ontario have examined their water quality benefits, as shown in Table 6 below.

Table 6 Pollutant removal efficiencies for soakaways, infiltration trenches and percentage of perforated pipe systems (Credit Valley Conservation (CVC); Toronto and Region Conservation (TRCA), 2010)

\begin{tabular}{|l|l|l|c|c|c|c|c|c|}
\hline BMP & Reference & Location & Lead & Copper & Zinc & TSS $^{2}$ & TP $^{3}$ & TKN $^{4}$ \\
\hline Soakaway & $\begin{array}{l}\text { Barraud et } \\
\text { al. (1999) }\end{array}$ & $\begin{array}{l}\text { Valence, } \\
\text { France }\end{array}$ & 98 & NT & $\begin{array}{c}54 \text { to } \\
88\end{array}$ & NT & NT & NT \\
\hline $\begin{array}{l}\text { Infiltration } \\
\text { trench }\end{array}$ & $\begin{array}{l}\text { ASCE } \\
(2000)^{5}\end{array}$ & Various & $\begin{array}{c}70 \text { to } \\
90\end{array}$ & 70 to 90 & $\begin{array}{c}70 \text { to } \\
90\end{array}$ & $\begin{array}{c}70 \text { to } \\
90\end{array}$ & $\begin{array}{c}50 \text { to } \\
70\end{array}$ & $\begin{array}{c}40 \text { to } \\
70\end{array}$ \\
\hline $\begin{array}{l}\text { Grass } \\
\text { swale/ } \\
\text { perforated } \\
\text { pipe system }\end{array}$ & $\begin{array}{l}\text { SWAMP } \\
(2002)\end{array}$ & $\begin{array}{l}\text { North York, } \\
\text { Ontario }\end{array}$ & 75 & 96 & 93 & 24 & 84 & 84 \\
\hline $\begin{array}{l}\text { Grass } \\
\text { swale/ } \\
\text { perforated } \\
\text { pipe system }\end{array}$ & $\begin{array}{l}\text { J.F. Sabourin } \\
\text { \& Associates } \\
\text { (2008a) }\end{array}$ & $\begin{array}{l}\text { Nepean, } \\
\text { Ontario }\end{array}$ & $>99^{6}$ & 66 & 0 & 81 & 81 & 72 \\
\hline $\begin{array}{l}\text { Grass } \\
\text { swale/ } \\
\text { perforated } \\
\text { pipe system }\end{array}$ & $\begin{array}{l}\text { J.F. Sabourin } \\
\text { \& Associates } \\
\text { (2008a) }\end{array}$ & $\begin{array}{l}\text { Nepean, } \\
\text { Ontario }\end{array}$ & $>99^{6}$ & $>99^{6}$ & 90 & 96 & 93 & 93 \\
\hline
\end{tabular}

Etobicoke exfiltration system was first developed and constructed in 1993 by the City of Etobicoke in the Greater Toronto Area (GTA), Ontario. The main objective of EES is to retrofit the conventional storm sewer system without end-of-pipe treatment for stormwater quality control. In addition, EES is one of the solutions in response to the new direction set by the Province of Ontario Interim Stormwater Quality Control Guidelines for New Development (MOEE and MNR, 1991). As indicated in Figure 3 and 4, two perforated pipes are installed below the main stormwater sewer. Runoff from catch basin enters the main 
stormwater sewer. With the level of stormwater in the manhole increases, stormwater runs into the perforated pipes first and then exfiltrates into the gravel trench. The whole exfiltration system is embedded in a gravel-filled trench, which is designed to meet stormwater requirements and is separated from the local soils with a geotextile fabric. The two perforated pipes have the same slope as the storm sewers and are wrapped by the filter cloth to prevent the pollutant from entering the trench. A goss trap is designed to trap the pollutants in the high traffic areas as well as the old municipality areas, where floatables and spills occur frequently. In order to prevent the soil and water in the trench from migrating to the downstream trench, the cut-off walls are added in the EES. A mechanical plug is designed to be installed at each downstream manhole; however, during construction this plug is located in the upstream to protect the perforated pipes from being clogged by the construction material.

Benefits of EES include that it can be used throughout the year and achieve the objective of controlling runoff intensity, volume, quality, duration and frequency (Ternier, 2012). Compared to other infiltration facilities, EES is intended to eliminate the need to reconstruct and replace the filtration medium (A.M. Candaras Associates Inc., 1997). 


\section{Etobicoke Exfiltration System}

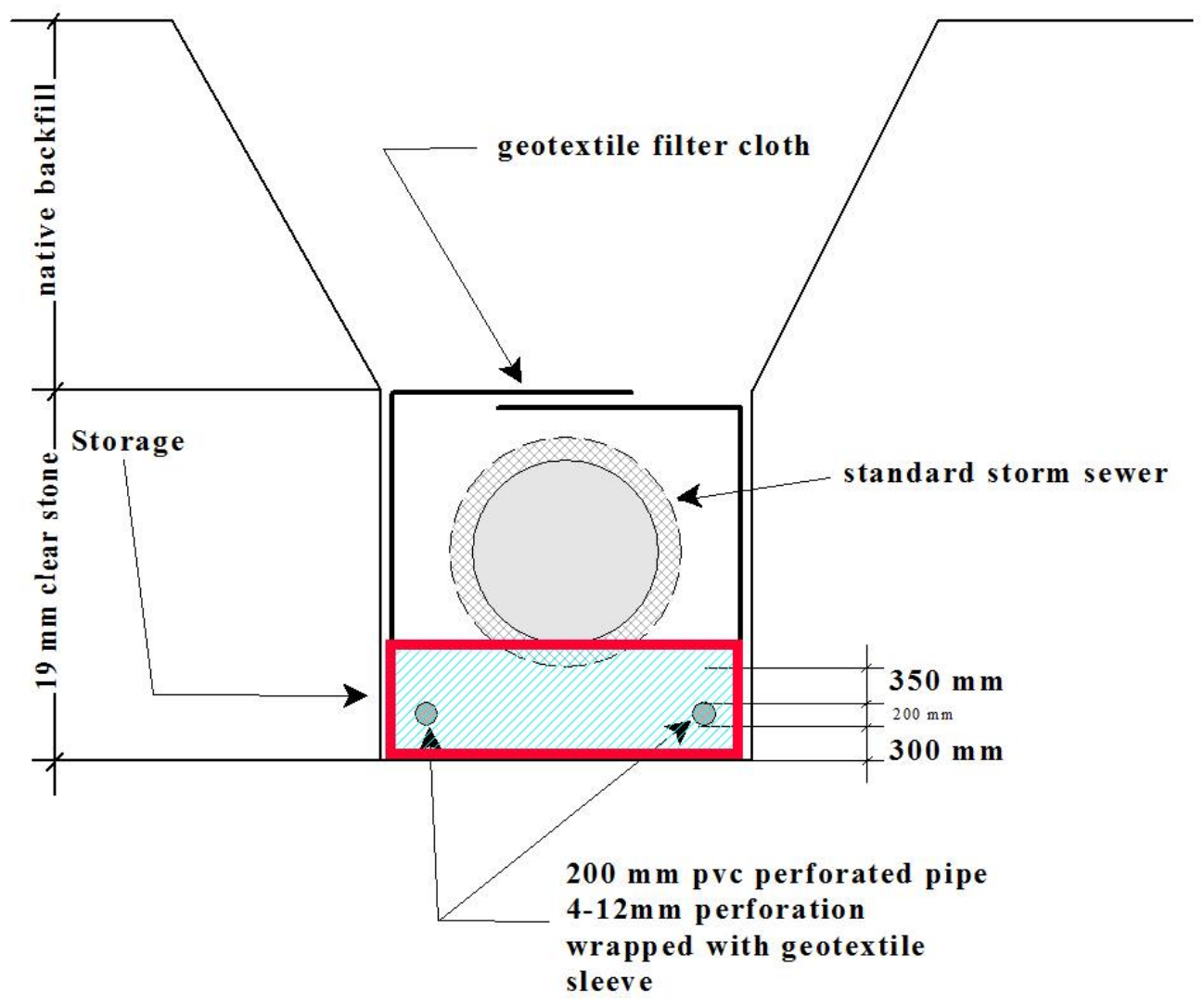

Figure 3 Cross-section of constructed EES

(A.M. Candaras Associates Inc., 1997) 


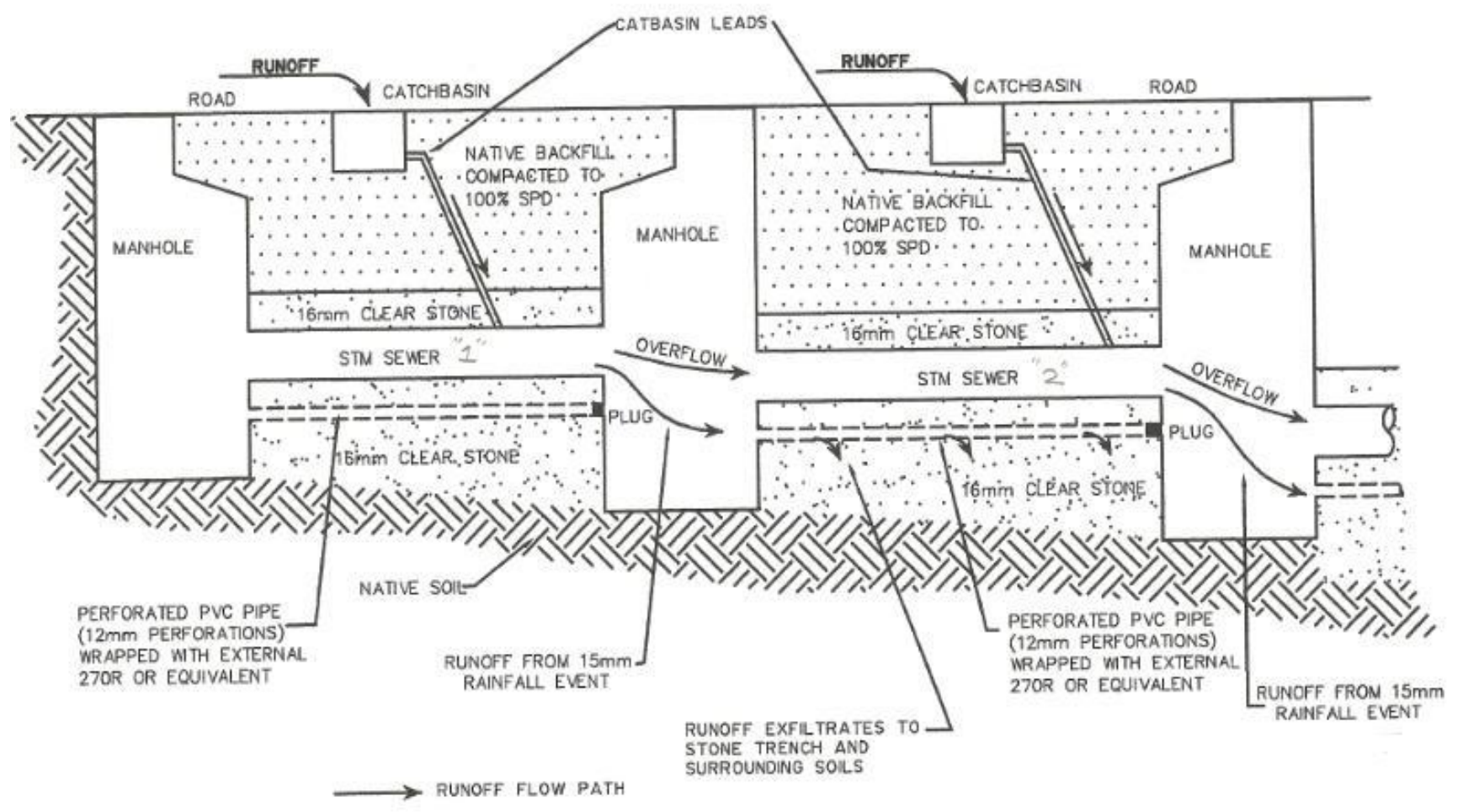

Figure 4 Typical profile of EES (A.M. Candaras Associates Inc., 1997)

Three basic design criteria of Etobicoke exfiltration system is as following (Stormwater Assessment Monitoring and Perfomance Program, 2004):

- Ground water is not used as a source of water supply;

- Groundwater table must be below trench elevation;

- Low risk of hazardous spills, best for low density residential areas; and

- Soil hydraulic conductivity should be reasonable for exfiltration.

Two sites of Etobicoke exfiltration system were designed and constructed between 1992 and 1994, Princess Margaret Boulevard and Queen Mary’s Drive. Monitoring was undertaken at the Princess Margaret Boulevard site in 1997 and 1998. The system was found to have the capability to exfiltrate the expected $15 \mathrm{~mm}$ rainfall events as only 3 of the 14 rainfalls that 
exceeded $15 \mathrm{~mm}$ caused overflows. The EES is sensitive to the rate of runoff and antecedent conditions and the limitation parameter is the throughout capacity.

Analysis of a limited set of sediment samples indicated that heavy metal concentrations were generally higher than those of stormwater retention pond sediments (A.M. Candaras

Associates Inc., 1997). The water quality data was limited for monitoring because of a lack of measurable flow data and the small numbers of overflow events.

Furthermore, EES can be designed to handle the runoff from extreme summer, winter and early spring events (Ternier, 2012). Ontario's four distinct seasons, fall, winter, spring and summer, each have their unique climate and rainfall patterns in regard to precipitation volume, intensity, frequency, duration, and direction (Singh, 1997). Cao et al. (2009) found that summer (mid June to August) had most of the severe rainfall events. Dichkinson (2010) supported the results by showing that in Southern Ontario, the return period for an event with a specific rainfall volume and duration decreased in summer compared with spring or fall. High intensity and short duration storm events in early fall (September and October) is similar to summer; however, as temperature falls in November, the rainfall events tend to be of medium intensity and long duration.

Winter (December to mid March) and spring (mid March to mid June) in Ontario is generally in the form of low intensity and long duration events (MOE, 2003). There are few runoff problems in winter as the cold weather keeps the snow with a frost layer on the top of the soil. However, once melting begins, the runoff needs taking care of (Ternier, 2012). Vink and Chin (2004) analyzed flow data from 1955 to 1997 for four streams in the GTA and found that spring had the highest peak mean daily flows. There are three different methods of snowmelt: pavement melt, road melt, and pervious area melt. The last two methods occur 
periodically during the winter and lead to large peak flows with rain or snow events at the end of winter (Roseen, et al., 2009). Snow can accumulate pollutants from the air as well as contaminants from the ground and the soluble pollutants will percolate downwards and accumulate at the bottom with snow pack melting (Oberts, 2000). Due to the below freezing temperatures that are typical of winters in Ontario and similar cold climate countries, infiltration and filtration stormwater management practices have been viewed with hesitation (Roseen, et al., 2009).

Many northern cold climate countries have focused on stormwater management based on cold climates and Ontario is no exception (Ternier, 2012). Most of the stormwater infrastructures are designed based on rainfall from summer and fall, without considering rain on snow events. Rain-on-snow events bring many problems such as resulting erosion as well as accumulation of pollutants like suspended solids and heavy metal. Existing stormwater management facilities have few methods for dealing with these problems. MOE SWM Planning and Design (2003) shows that infiltration trenches and bioretention systems are inappropriate for water quality treatment during winter and spring due to limited capacity from freezing or soil saturation. Although several recent sources assert that bioretention systems function in cold climate as frozen media has minimal effect on hydraulic function, more investigations need to be done (Roseen R., et al., 2009)(Davidson, LeFevre, \& Oberts, 2008)Wet ponds are recommended for water quality control during winter and spring. However, ponds may easily become stratified during hot summers with $3 \mathrm{~m}$ or greater depth (Ministry of Environment (MOE), 2003). 


\subsubsection{Wet Ponds}

End-of-pipe stormwater management facilities include wet ponds, wetlands, dry ponds and infiltration basins (Ministry of Environment (MOE), 2003). The difference between wet ponds and wetlands is the proportions of deep $(>0.5 \mathrm{~m})$ and shallow $(<0.5 \mathrm{~m})$ areas. The deep zones of wet ponds take around $80 \%$ surface of the facilities.

Virtually all the new wet facilities designed in Ontario have an extended detention storage component in need of multi-purpose design, which is used during and after a runoff event. (Ministry of Environment (MOE), 2003)

During the last 10 to 15 years, wet ponds have become an increasingly popular best management practice in Ontario. Binstock (2011) indicated that stormwater management in Ontario has primarily used conveyance and end-of-pipe controls, with the main choice being detention ponds among all the variety of stormwater facilities.

The performance of a wet pond is time dependent and steadily decreases as sediment accumulation occurs. Thus maintenance becomes necessary for wet ponds to keep meeting the regulation for discharged water quality. There are several factors impacting the maintenance of wet ponds, such as storage volume, rainfall intensity and duration, construction activities, street sweeping, and characteristics of the pond drainage area (Ministry of Environment (MOE), 2003).The literatures describe annual maintenance costs as a percentage of construction costs or a function of the pond's design storage volume, or as a function of the subcatchment area. 


\subsection{Best Management Practices}

In response to the detrimental ecological stresses that urbanization places on a watershed, best management practices (BMPs) have been developed to reduce water quantity impacts and water quality constituents (Khowaja, 2007). BMPs can be either non-structural or structural. Non-structural BMPs include institutional, educational or pollution prevention practices designed to prevent pollutants from entering stormwater runoff or reduce the volume of stormwater requiring management (United States Environmental Protection Agency (US EPA), 1999). Infiltration systems, detention systems, retention systems etc. are structural BMPs designed to protect wetlands and ecosystems, improve water quality, protect water resources, and control floods (United States Environmental Protection Agency (US EPA), 1999). Some BMPs may enhance recharge, which is often considered a secondary management benefit (Newcomer, Gurdak, Sklar, \& Nanus, 2014). However, BMPs have little effect on inadequate base flow, flashy hydrology and other hydrologic development impact (Coffman, 2000; (United States Environmental Protection Agency (US EPA), 2000). Site suitability has a significant effect on the performance of BMPs strategies; therefore, several factors such as drainage areas, land uses, average rainfall frequency, duration and intensity, and soil types should be taken into consideration.

\subsection{Stormwater Management Models}

Water resource computer models are very important tools for evaluating pre- and postdevelopment conditions (Toronto and Region Conservation, 2012). Several models are recommended within TRCA's jurisdiction for the purpose of analyzing hydrology, hydraulics and water balance. Stormwater Hydrology models are categorized as single event and 
continuous simulation. Event based modelling is used to input individual events for establishing flow rates and for designing peak reduction and attenuation facilities (Toronto and Region Conservation, 2012). In contrast, a continuous model can be used to input longterm precipitation events for long term simulation as well as evaluation of erosion potential (Toronto and Region Conservation, 2012). MIDUSS is one of the event based stormwater models with an EES modelling option (Richard, 2013). Ternier (2012) calibrated an EES using MIDUSS to analyze its effectiveness under various synthetic storm events.

The EPA Storm Water Management Model (SWMM) is a dynamic rainfall-runoff simulation model used for single or long-term (continuous) simulation of runoff quantity and quality from primarily urban areas (Rossman, 2008). Thousands of studies have already been conducted to simulate non-point pollution sources and the transport of pollutants (Rossman, 2008). Some of the studies used SWMM to simulate LID and consequently discovered some of SWMM's deficiencies. McCutcheon and Wride (2013) found that in SWMM there were differences between LID parameters for single event and long-term parameters, that moisture conditions before a storm may influence LID infiltration capacity, that during short-term storms it is easier to compensate for clogging or debris, and that gaps existed between their field observations and model results. 


\section{Chapter 3 Modelling Approaches}

\subsection{Etobicoke Exfiltration System (EES)}

The area selected for the investigation of modelling approaches for EES is located at the Princess Margaret Boulevard. This site (one of the three demonstration sites) was monitored by the Stormwater Assessment Monitoring and Performance Program's staff (SWAMP) from 1996 to 1998 (SWAMP 2004). Various modelling approaches were conducted on the first upstream section of EES (between $\mathrm{MH}_{2}$ and $\mathrm{MH}_{3}$ ) because of the available monitored data. The soil type of this area is silty sandy to clayed silt (A.M. Candaras Associates Inc., 1997). The storm event, "October 5-6, 1995", monitored at Toronto Lester B. Pearson International Airport rainfall station with Climate ID 6158733, was used as rainfall input to calibrate EES using various modelling approaches. The storm duration was 18 hours with $63 \mathrm{~mm}$ of rainfall, as shown in Figure 5. The measured trench hydraulics (i.e. flows and heads) of the EES for the event on October 5-6th, 1995 is shown in Figure 6.The trench data are listed in Table 7. 


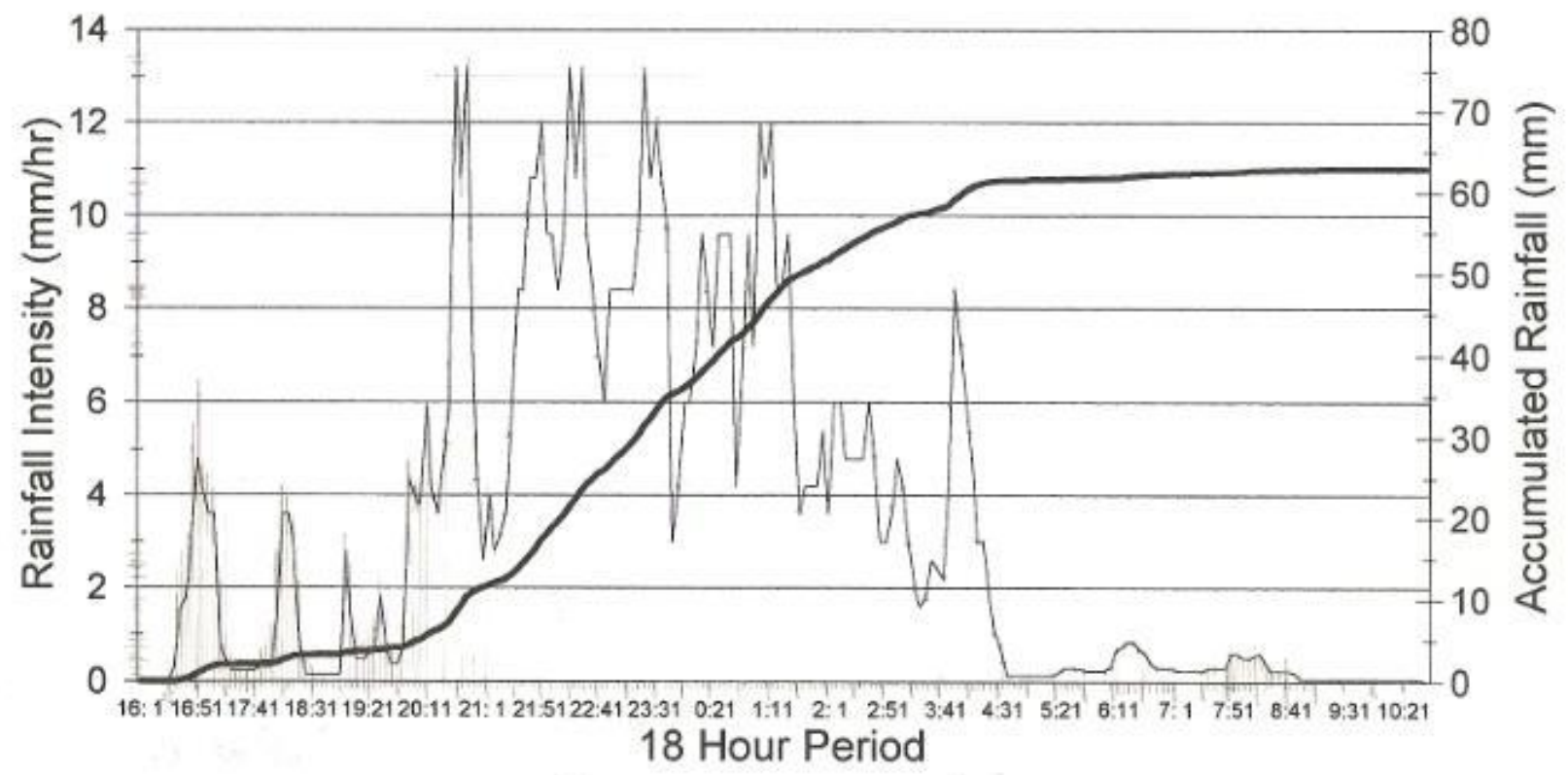

\section{Intensity - Accumulated Rainfall}

Figure 5 Rainfall hyetograph of October 5-6, 1995 historic event (A.M. Candaras Associates

Inc., 1997) 


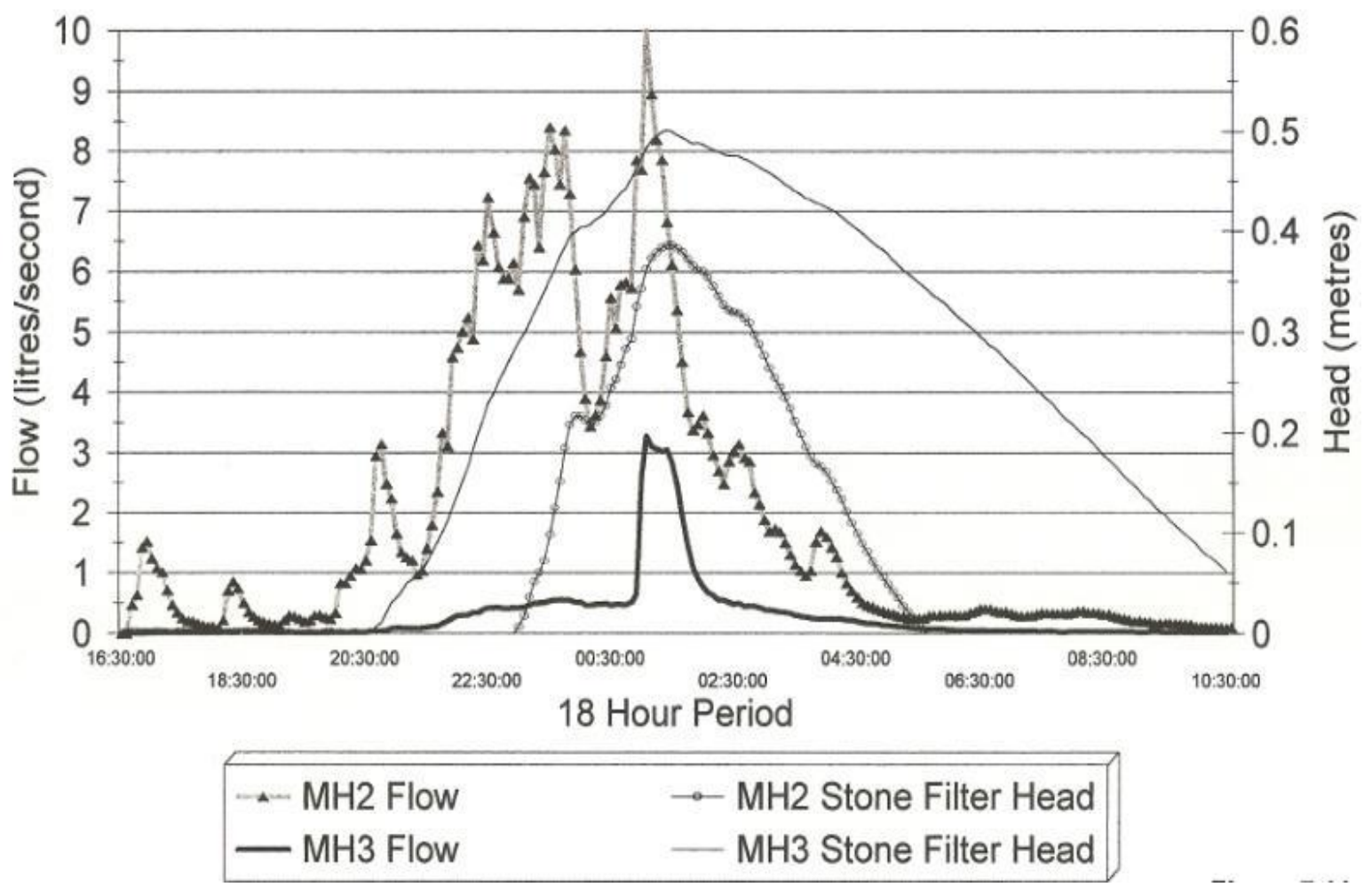

Figure 6 Measured trench hydraulics of EES for the Oct. 5-6, 1995 historic event

(A.M. Candaras Associates Inc., 1997)

Table 7 Trench parameters between MH2 and MH3 (Tran \& Li, 2015)

\begin{tabular}{|c|c|}
\hline \multicolumn{2}{|c|}{ Trench Data: } \\
\hline Ground elevation $(\mathrm{m})$ & 158 \\
Downstream trench invert $(\mathrm{m})$ & 154.17 \\
Trench height $(\mathrm{m})$ & 1.5258 \\
Water table elevation $(\mathrm{m})$ & 10 \\
Trench top width $(\mathrm{m})$ & 2.2758 \\
Trench bottom width $(\mathrm{m})$ & 2.2758 \\
Voids ratio $(\%)$ & 40 \\
$\mathrm{~K}(\mathrm{~mm} / \mathrm{hr})$ & 0.0252 \\
Trench gradient $(\%)$ & 0.73 \\
Trench length $(\mathrm{m})$ & 96.95 \\
Trench volume $\left(\mathrm{m}^{3}\right)$ & 134.8 \\
Access riser diameter $(\mathrm{m})$ & 1.2 \\
\hline
\end{tabular}




\subsubsection{The MIDUSS Modelling Approach}

MIDUSS has a modelling option of perforated pipes underneath a storm sewer and is used by Ternier (2012) to model EES. In this study, the monitored rainfall data in Figure 5 were input into MIDUSS, and then catchment and trench parameters were calibrated with the measured trench hydraulics as shown in Table 8 and 9.

Table 8 Calibrated catchment parameters

\begin{tabular}{|l|c|}
\hline \multicolumn{2}{|c|}{ Catchment Parameters } \\
\hline \% Impervious & 15 \\
Total Area ${ }^{1}$ & 0.88 \\
Flow Length & 300 \\
Overland Slope \% ${ }^{1}$ & 0.45 \\
Routing Method & swMM method \\
Pervious \& Impervious Flow & Prop. to \% \\
Length & \\
\hline \multicolumn{2}{|c|}{ Pervious Parameters } \\
\hline Pervious Slope \% & 0.45 \\
Manning 'n' & 0.03 \\
Max. Infiltration (mm/hr) & 80 \\
Min. Infiltration (mm/hr) & 5.8 \\
Lag constant (hr) & 0.2 \\
Depression storage (mm) & 2 \\
Infiltration Method ${ }^{1}$ & Horton Eq. \\
\hline \multicolumn{2}{|c|}{ Impervious Parameters } \\
\hline Impervious Slope \% & 0.45 \\
Manning 'n' & 0.013 \\
Max. Infiltration (mm/hr) & 0 \\
Min. Infiltration (mm/hr) & 0 \\
Lag constant (hr) & 0 \\
Depression storage (mm) & 0.5 \\
\hline
\end{tabular}

${ }^{1}$ Fixed parameters (not modified) 
Table 9 Calibrated trench parameters

\begin{tabular}{|l|c|}
\hline \multicolumn{2}{|c|}{ Outflow Data (Storm Sewer): } \\
\hline Upstream invert level (m) & 155.589 \\
Downstream invert level (m) & 154.879 \\
Pipe length (m) & 96.95 \\
Pipe diameter (m) & 0.45 \\
Manning's 'n' & 0.013 \\
Entry loss Ke & 0.5 \\
\hline
\end{tabular}

Storm sewer pipes and perforated pipes could be modelled by MIDUSS with the parameters as shown in Table 10. Pipe 1 was the traditional storm sewer pipe and Pipe 2 and Pipe 3 were perforated pipes.

Table 10 Pipe parameters used in MIDUSS

\begin{tabular}{|l|c|c|c|}
\hline \multicolumn{1}{|c}{ Trench pipes: } & \multicolumn{1}{c}{ Pipe 1 } & \multicolumn{1}{c|}{ Pipe 2 } & Pipe 3 \\
\hline Downstream Invert (m) & 154.879 & 154.47 & 154.47 \\
Pipe Length (m) & 96.95 & 96.95 & 96.95 \\
Pipe Diameter (m) & 0.45 & 0.2 & 0.2 \\
Pipe Grade (\%) & 0.73 & 0.73 & 0.73 \\
Perforated? & No & Yes & Yes \\
\hline
\end{tabular}

MIDUSS was calibrated to match the measure overflow along the storm sewer. Since MIDUSS is an event-based simulation model, it could not be used to simulate long-term runoff control performance.

\subsubsection{Channel-Storage Modelling Approach}

Although SWMM has a variety of options to model different LID practices (e.g. BioRetention Cell, Rain Garden, Green Roof, Infiltration Trench, Permeable Pavement, Rain Barrel and Vegetative Swale), it does not have a modelling option for EES. As a result, several different modelling approaches are proposed in this study to model EES using 
SWMM. As the inflow of $\mathrm{MH}_{2}$ (upstream manhole of EES section of interest) was measured, it could be input directly into the model as junction's inflow in SWMM.

The modelling approach using the Channel-Storage method in SWMM is represented in Figure 7. The $\mathrm{MH}_{2}$ inflow hydrograph in Figure 6 was input directly into $\mathrm{MH}_{2}$ in format of time series. The trench was represented as a conduit in SWMM, which could be either closed or open rectangle. The EES design manual (Tran \& $\mathrm{Li}, 2015)$ indicated that there was a plug at the end of each perforated pipe. Therefore, the plug could be represented as the dumbing storage 'Dstorage', which should be storage with 0 volumes and no seepage. Conduit 1 was the conventional storm sewer connecting $\mathrm{MH}_{2}$ and $\mathrm{MH}_{3}$. Manhole and conduit parameters could be converted from MIDUSS calibration into SWMM as shown in Table 11 and Table 12. The rectangular channel was the same size as the trench height $(1.5 \mathrm{~m})$ and trench length (97m).The void ratio of the trench was 0.4 , which meant $40 \%$ of the designed trench could hold the stormwater. In order to represent the valid size of trench, the width was reduced $60 \%$ from $2.3 \mathrm{~m}$ to $0.9 \mathrm{~m}$.

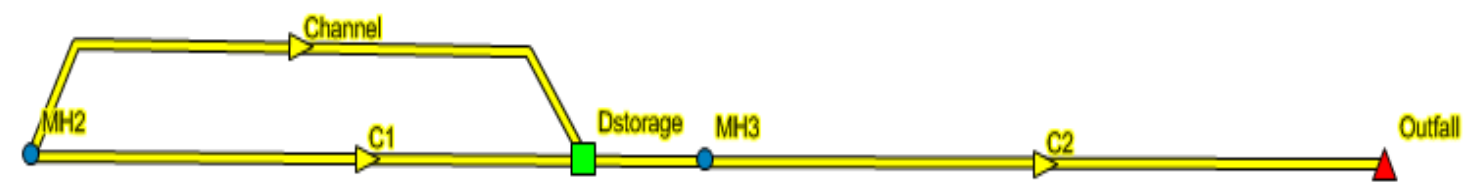

Figure 7 Representation of Channel-Dumbing Storage 
Table $11 \mathrm{MH}$ parameters used in SWMM

\begin{tabular}{|c|c|c|}
\hline \multicolumn{3}{|c|}{ MH parameters } \\
\hline Name & $\mathrm{MH}_{2}$ & $\mathrm{MH}_{3}$ \\
\hline Invert Elev(m) & 154.877 & 154.17 \\
\hline Depth(m) & 3.123 & 3.83 \\
\hline
\end{tabular}

Table 12 Conduit parameters used in SWMM

\begin{tabular}{|c|c|c|}
\hline \multicolumn{3}{|c|}{ Conduit parameters } \\
\hline Name & $\mathrm{C} 1$ & $\mathrm{C} 2$ \\
\hline Length(m) & 96.95 & 96.95 \\
\hline Roughness & 0.013 & 0.013 \\
\hline Inlet Offset(m) & 0.709 & 0.709 \\
\hline Outlet Offset(m) & 0.709 & 0.709 \\
\hline Cross-Section & CIRCULAR & CIRCULAR \\
\hline Geom1(m) & 0.45 & 0.45 \\
\hline
\end{tabular}

Since SWMM Version 5.1 includes a new "Seepage Rate $(\mathrm{mm} / \mathrm{hr})$ " function of conduits, it was used to model EES. If the Seepage Rate is the rate of water flowing out from perforations along a conduit; it should be equal to the soil conductivity. The Seepage Rate of conduit was changed within a reasonable soil conductivity range of $20-70 \mathrm{~mm} / \mathrm{hr}$ to test whether it could simulate the exfiltrating rate of the perforated pipes.

\subsubsection{Orifice-Storage Modelling Approach}

A representation of the Orifice-Storage method in SWMM is shown in Figure 8. In this method, manholes and conduits were set up same as Channel-storage method. However, trench was represented by storage instead of channel. Two orifices represented the inlet of the perforated pipes, so the inlet offset was $0.3 \mathrm{~m}$. The height of the orifice was $0.2 \mathrm{~m}$, which 
was same as the diameter of the perforated pipes. Stormwater flowed through orifices and then stored in the storage. The orifice parameters are shown in Table 13.

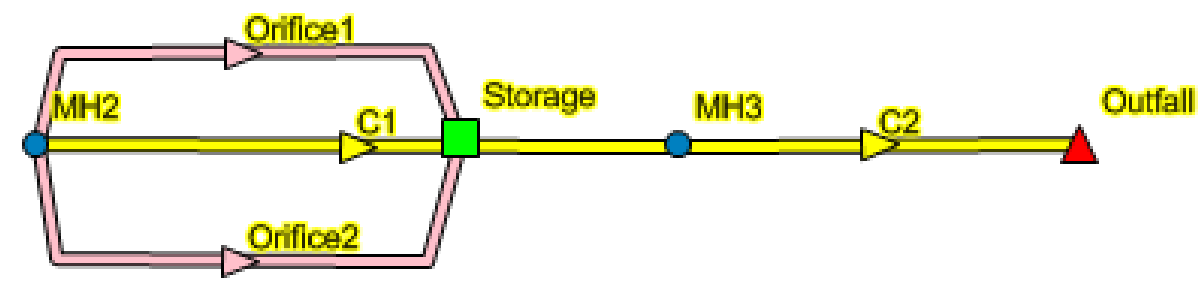

Figure 8 Representation of Orifice-Storage system in SWMM

Table 13 Orifice parameters used in SWMM

\begin{tabular}{|c|c|c|}
\hline \multicolumn{3}{|c|}{ Orifice parameters } \\
\hline Name & Orifice 1 & Orifice 2 \\
\hline Type & SIDE & SIDE \\
\hline Cross-Section & CIRCULAR & CIRCULAR \\
\hline Height(m) & 0.2 & 0.2 \\
\hline Inlet Offset $(\mathrm{m})$ & 0.3 & 0.3 \\
\hline Discharge Coeff. & 0.65 & 0.65 \\
\hline
\end{tabular}

As a storage element was used to represent the trench, the parameters of the storage could be converted from the trench parameters. The width of storage was $0.9 \mathrm{~m}$ and the length of storage was $97 \mathrm{~m}$. The elevation of the storage bottom was $155 \mathrm{~m}$, the same as $\mathrm{MH}_{3}$.

In SWMM, the Storage curve is used to describe how the surface area of the storage unit varies with the water depth. There are two types of storage curve: one is termed FUNCTIONAL in which the function of Area $=A \times D e p t^{B}+C$ is specified by the user; the other is termed TABULAR in which a tabulated area versus depth curve is specified by the user. In this research, FUNCTIONAL was chosen to describe how surface area changed in 
terms of water depth. Stormwater would accumulate at the end of the storage at first and then rise up in the storage. Figure 9 shows the trench's space diagram.

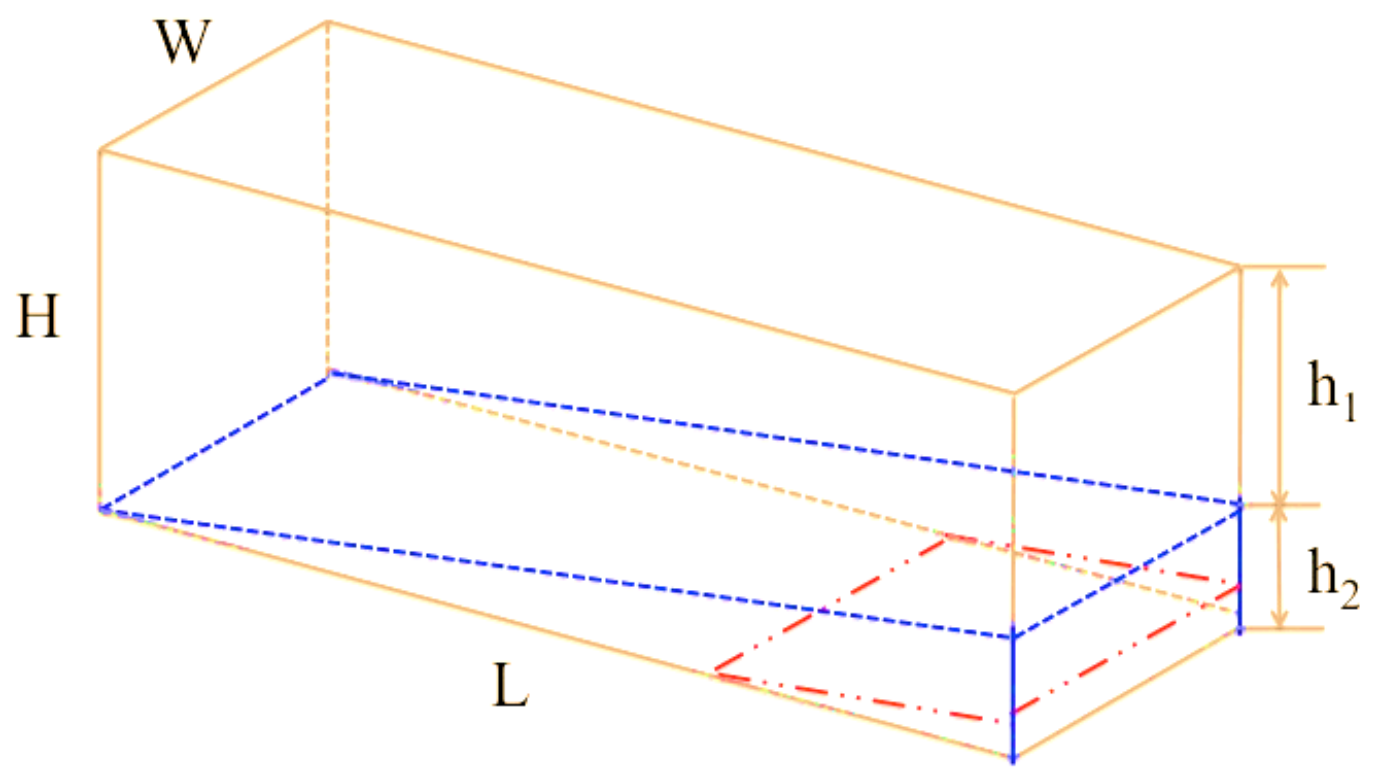

Figure 9 Trench graphic model representations in SWMM

Before the stormwater reached the elevation of the upstream storage bottom $\mathrm{h}_{2}$, the profile's shape of storage filling with stormwater was triangular prism. Therefore, the surface area could be calculated by Equation 3.1.

Surface area $=$ Width of the trench $\times \frac{\mathrm{h}}{\text { trench slope }}=0.4 \times 2.3 \times \frac{\mathrm{h}}{\frac{0.709}{96.95}}=125.8 \times \mathrm{h}\left(\mathrm{m}^{2}\right)(\mathrm{h}<\mathrm{H})(\mathrm{Eq} 3.1)$

In which ' $h$ ' was the depth of stormwater in trench and h should be less than the trench height $\mathrm{H}(1.5 \mathrm{~m})$.

As long as the stormwater depth was over $\mathrm{h}_{2}$, stormwater would accumulate in rectangle profile shape, which meant the surface area would keep the same when $\mathrm{h}$ was more than $\mathrm{h}_{2}$. In the seepage function of storage, there are three options: suction head (mm), conductivity $(\mathrm{mm} / \mathrm{hr})$, and initial deficit. Suction head could be chosen from Table 14 as $11.42 \mathrm{~mm}$ 
initially. Conductivity was assumed to be the calibrated value from MIDUSS $27 \mathrm{~mm} / \mathrm{hr}$.

Initial deficit was 0 for constant seepage rate equal to conductivity.

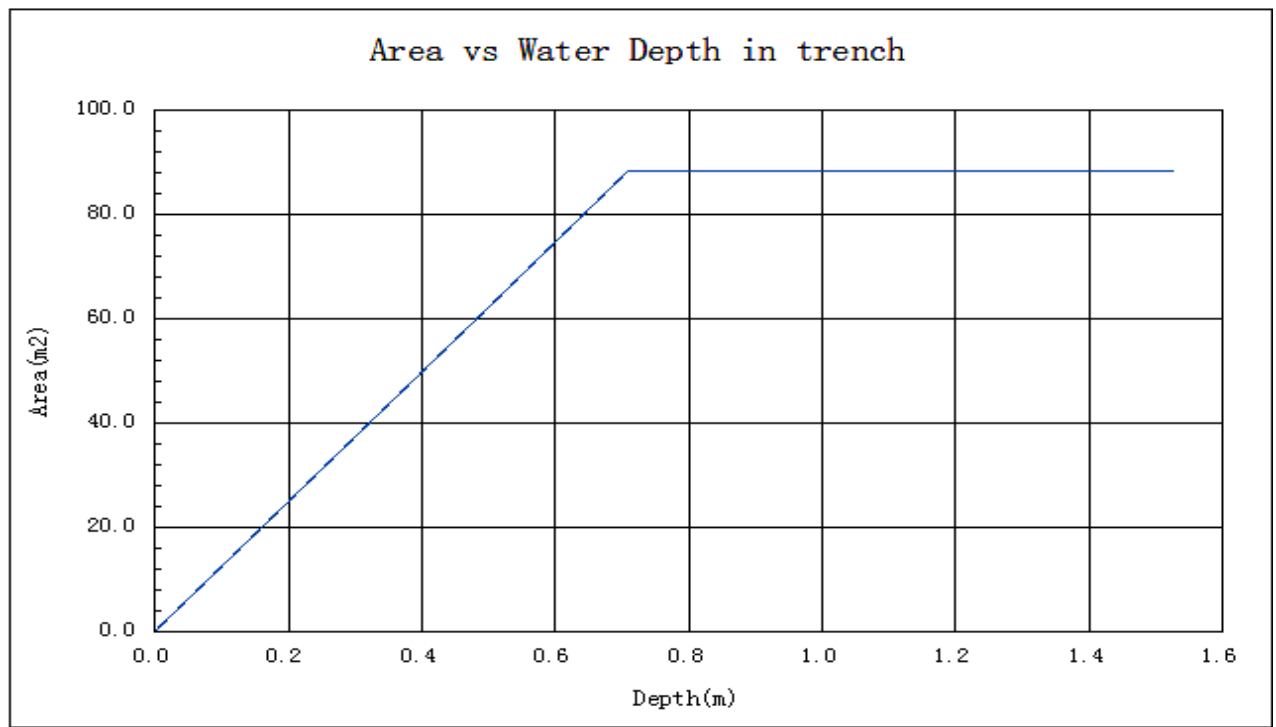

Figure 10 Surface area-water depth in trench

\subsubsection{Orifice-Storage-Pump Modelling Approach}

A representation of the Orifice-Storage-Pump System in SWMM is shown in Figure 11. The parameters of manholes, conduits and orifices were the same as the "Channel- Storage" method in Table 11, 12 and 13.

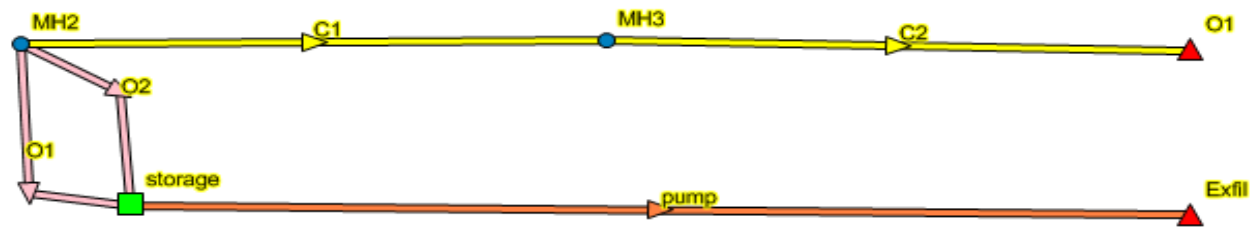

Figure 11 Representation of Orifice-Storage-Pump System in SWMM

In this method, a 'storage' was used to represent the trench dimension in SWMM, which could be represented by the FUNCTIONAL storage curve. This storage only represented the 
dimension of the trench holding stormwater; therefore, the storage wouldn't take trench slope and exfiltration rate into consideration. Thus, the Coefficient A and B were both assumed to be 0 in SWMM. The value of Coefficient $\mathrm{C}$ for the functional curve of the storage was set as the effective area of trench surface, which should be $88 \mathrm{~m}^{2}(0.9 \mathrm{~m} \times 97 \mathrm{~m})$ because of the $40 \%$ void rate. As this method didn't take trench slope into consideration, the elevation of the storage should be set same as the upstream elevation of the trench, which was the elevation of upstream $\mathrm{MH}_{2}$.

In order to model the trench slope and exfiltration rate, a pump was added to the storage. The pump curve represented the exfiltration rate of water flowing from both bottom and sides of the trench to surrounding soil. Therefore, the outflow from the perforated pipes Qoufflow(in terms of soil conductivity $\mathrm{k}$ for the pump curve) could be calculated by Equation 3.2, in which $\mathrm{W}$ was the width of the trench and $\mathrm{L}$ was the length of the trench. After the water depth $\mathrm{h}$ in the trench was over trench height $(1.5 \mathrm{~m})$, $\mathrm{Q}$ would become constant as shown in Figure 12.The designed value for the soil conductivity $\mathrm{k}$ was set according to calibrated hydraulic conductivity in MIDUSS.

$$
\begin{aligned}
& Q_{\text {outflow }}(\mathrm{L} / \mathrm{s})=\frac{\mathrm{k}\left(\frac{\mathrm{mm}}{\mathrm{hr}}\right)}{3600(\mathrm{~s} / \mathrm{hr}) \times 1000\left(\frac{\mathrm{mm}}{\mathrm{m}}\right)} \times \text { Wetted area }\left(\mathrm{m}^{2}\right) \times 1000\left(\mathrm{~L} / \mathrm{m}^{3}\right) \\
& =\left(\mathrm{k} / 3600 \times(\mathrm{W} \times 0.4+2 \times \mathrm{h}) \times \mathrm{L}\left(\frac{\mathrm{L}}{\mathrm{S}}\right)(\text { Eq 3.2) }\right.
\end{aligned}
$$




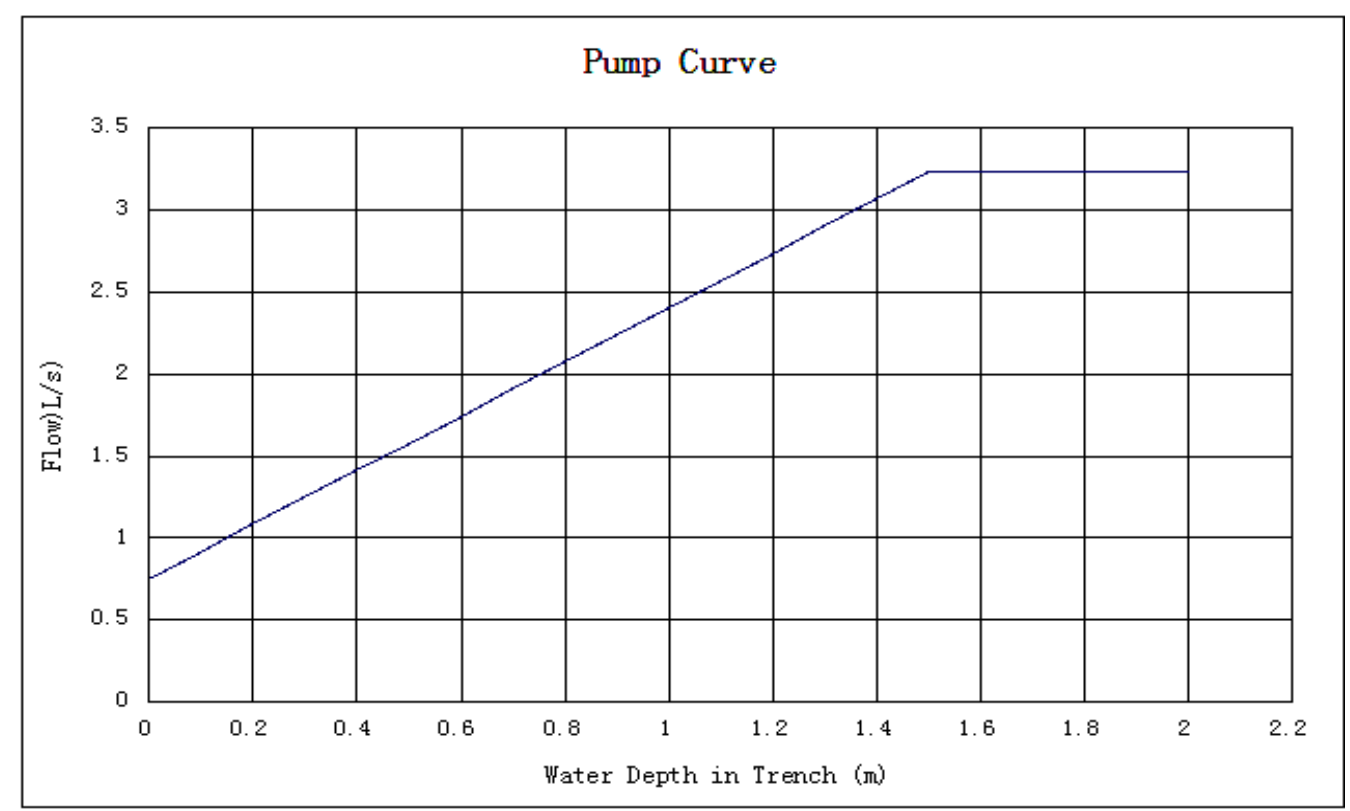

Figure 12 Pump curve in SWMM

\subsection{Model Test Analysis}

\subsubsection{Model Test in MIDUSS}

The modelling results of EES using MIDUSS show good agreement with the monitored overflow volume of $42.2 \mathrm{~m}^{3}$ and trench hydraulics, as shown in Figure 13. Peak flow reduced from $0.01 \mathrm{~m}^{3} / \mathrm{s}$ to $0.005 \mathrm{~m}^{3} / \mathrm{s}$. The calibrated hydraulic conductivity $\mathrm{k}$ was $27 \mathrm{~mm} / \mathrm{hr}$. Since MIDUSS is an event-based model, it cannot be used to simulate long-term performance of EES. 


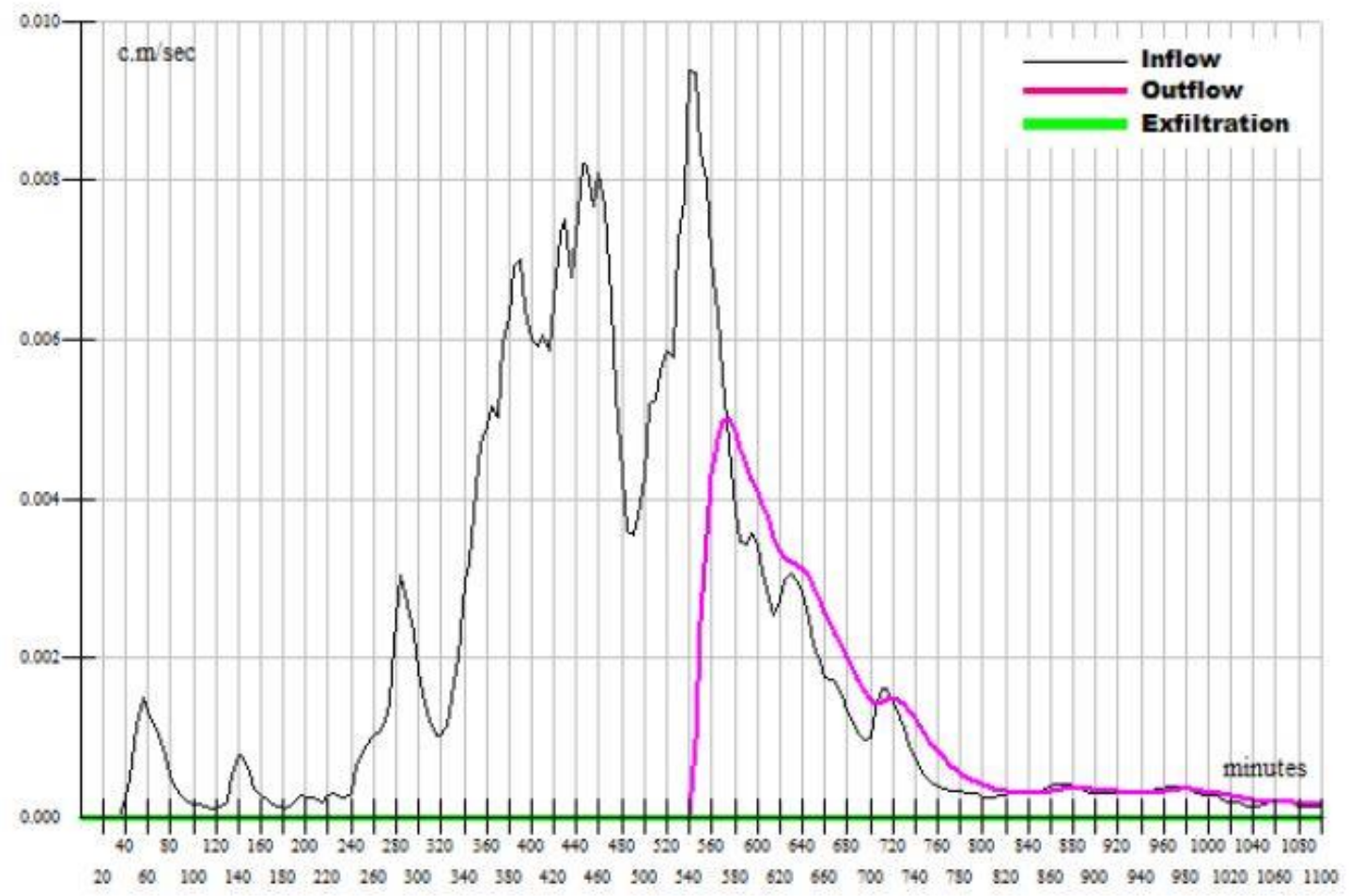

Figure 13 EES test results using MIDUSS

\subsubsection{Channel-Storage Method Test}

The Channel-Storage model was run with the designed parameters. Channel profile in SWMM showed stormwater flowed into the channel and stored in the wedge storage of channel. Total inflow was $129 \mathrm{~m}^{3}$ and $31 \mathrm{~m}^{3}$ exfiltrated from the channel. The rest $98 \mathrm{~m}^{3}$ flowed into the dumbing storage and finally flooded. The mean depth of the water in channel was $0.005 \mathrm{~m}$. Therefore, exfiltration rate k' in SWMM was calculated as follows:

$\mathrm{k}^{\prime}=\frac{\mathrm{Q}_{\text {exfil }} / 18 \mathrm{hr}}{\mathrm{S}}=\frac{31 / 18}{97 \times 0.91+97 \times 0.005 \times 2}=19.3 \mathrm{~mm} / \mathrm{hr}$

The exfiltration rate in SWMM was less than the designed $27 \mathrm{~mm} / \mathrm{hr}$. This smaller exfiltration rate indicates that the function of 'seepage rate' isn't equal to exfiltration rate. Additionally, 
the stormwater wouldn't stop flowing into the trench and accumulate in the $\mathrm{MH}_{2}$ when the water level was higher than the elevation of the orifices. As a result, no flow was detected in Conduit 1.

\subsubsection{Orifice-Storage Method Test}

The Orifice-Storage model was run with the designed parameters. From the Candara's' report (1997), $4 \mathrm{~m}^{3}$ of stormwater exfiltrated from storage and the rest $97 \mathrm{~m}^{3}$ of stormwater was stored in the wedge storage of trench. However, the continuity error was $-11 \%$.

The mean depth of the water in storage was $1 \mathrm{~m}$. Therefore, exfiltration rate could be calculated below but did not match the designed $27 \mathrm{~mm} / \mathrm{hr}$. This calculated exfiltration rate indicates SWMM won't exfiltrate the stormwater stored in trench. So in order to add the exfiltration rate into the model, a pump is added in the following method.

$$
K^{\prime}=\frac{Q_{\text {exfil }} / 18 \mathrm{hr}}{S}=\frac{4 / 18}{97 \times 0.91+97 \times 1 \times 2}=0.7 \mathrm{~mm} / \mathrm{hr}
$$

\subsubsection{Orifice-Storage-Pump Method Test}

The Orifice-Storage-Pump model was run with the designed parameters. After calibrating the $\mathrm{k}$ value to $32 \mathrm{~mm} / \mathrm{hr}$, the simulated outflow hydrograph was found to be in good agreement with to the measured data.

As can be seen from the flow curves in Figure 14, the inflow of $\mathrm{MH}_{2}$ is input data. After calibration, the peak flow in $\mathrm{MH}_{3}$ was $3 \mathrm{~L} / \mathrm{s}$, which was in good agreement with those observed. The minor flow of the observed $\mathrm{MH}_{3}$ flow was interpreted in Post-Construction Evaluation of EES as minor leakage through the connected catchbasins and the water entering through an abandoned culvert connection (A.M. Candaras Associates Inc., 1997). 


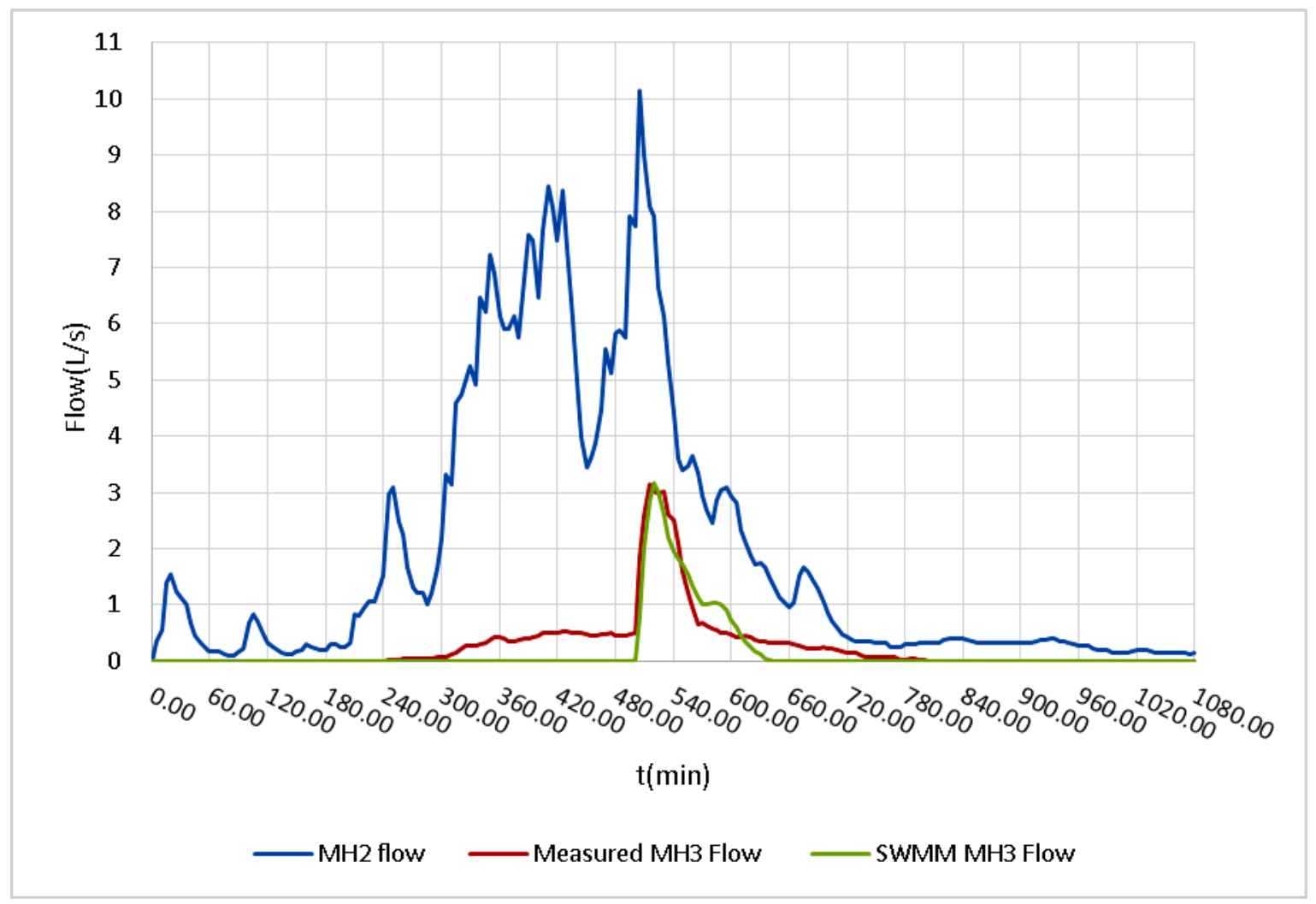

Figure 14 EES simulated results in SWMM for the Oct. 5-6, 1995 historic event.

The measured data was monitored in the trench at the elevation of the perforated pipes, which has a $0.3 \mathrm{~m}$ offset. Thus $0.3 \mathrm{~m}$ was set up as the base line head and all the results above the dashed line could be compared with the monitored results as shown in Figure 15. In order to plot the head graph, $0.3 \mathrm{~m}$ was subtracted by the SWMM results. The depth summary is shown in Figure 16 and 17. 


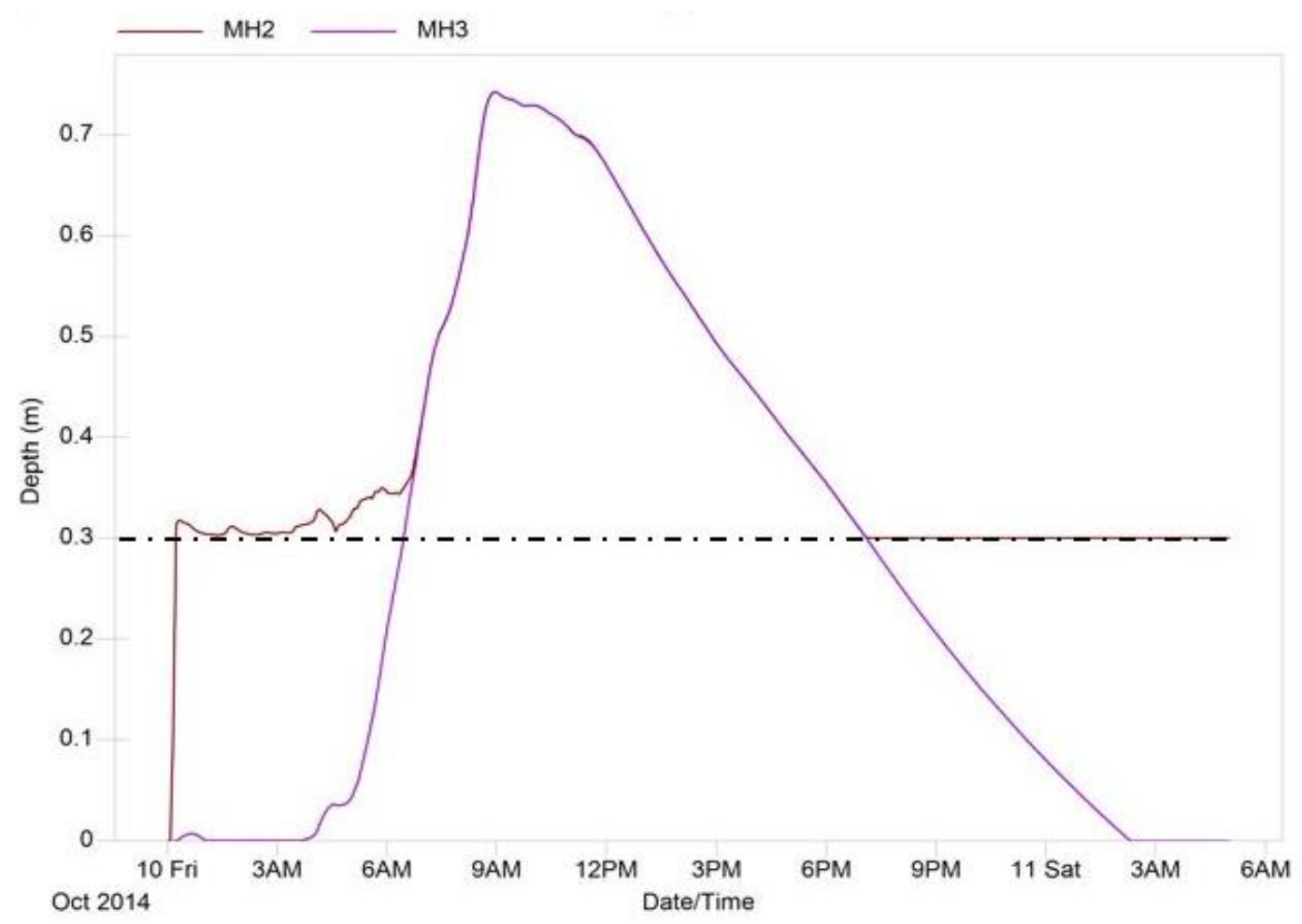

Figure 15 EES head results using SWMM

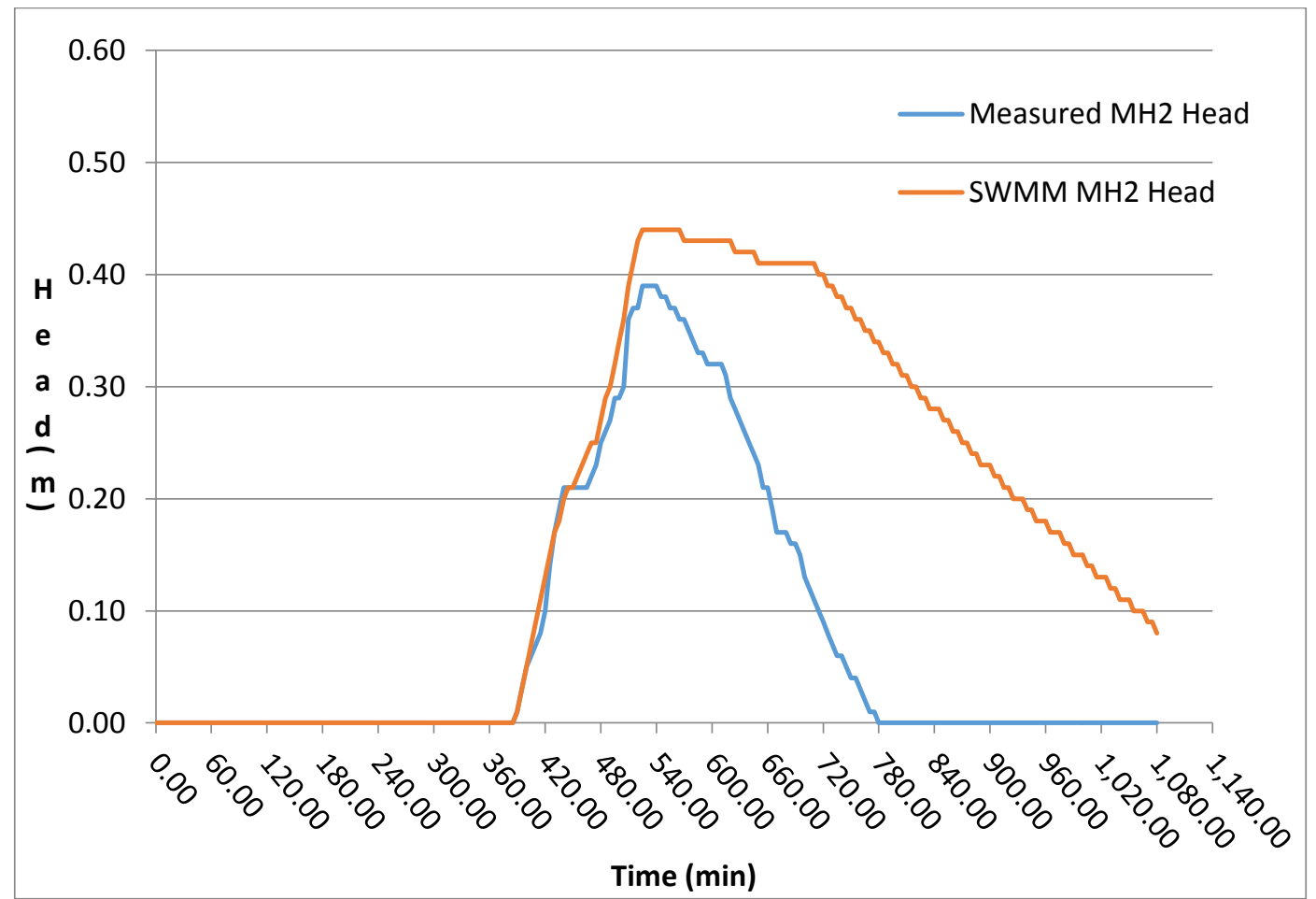

Figure $16 \mathrm{EES} \mathrm{MH}_{2}$ Head results compared with measured $\mathrm{MH}_{2} \mathrm{Head}$ 


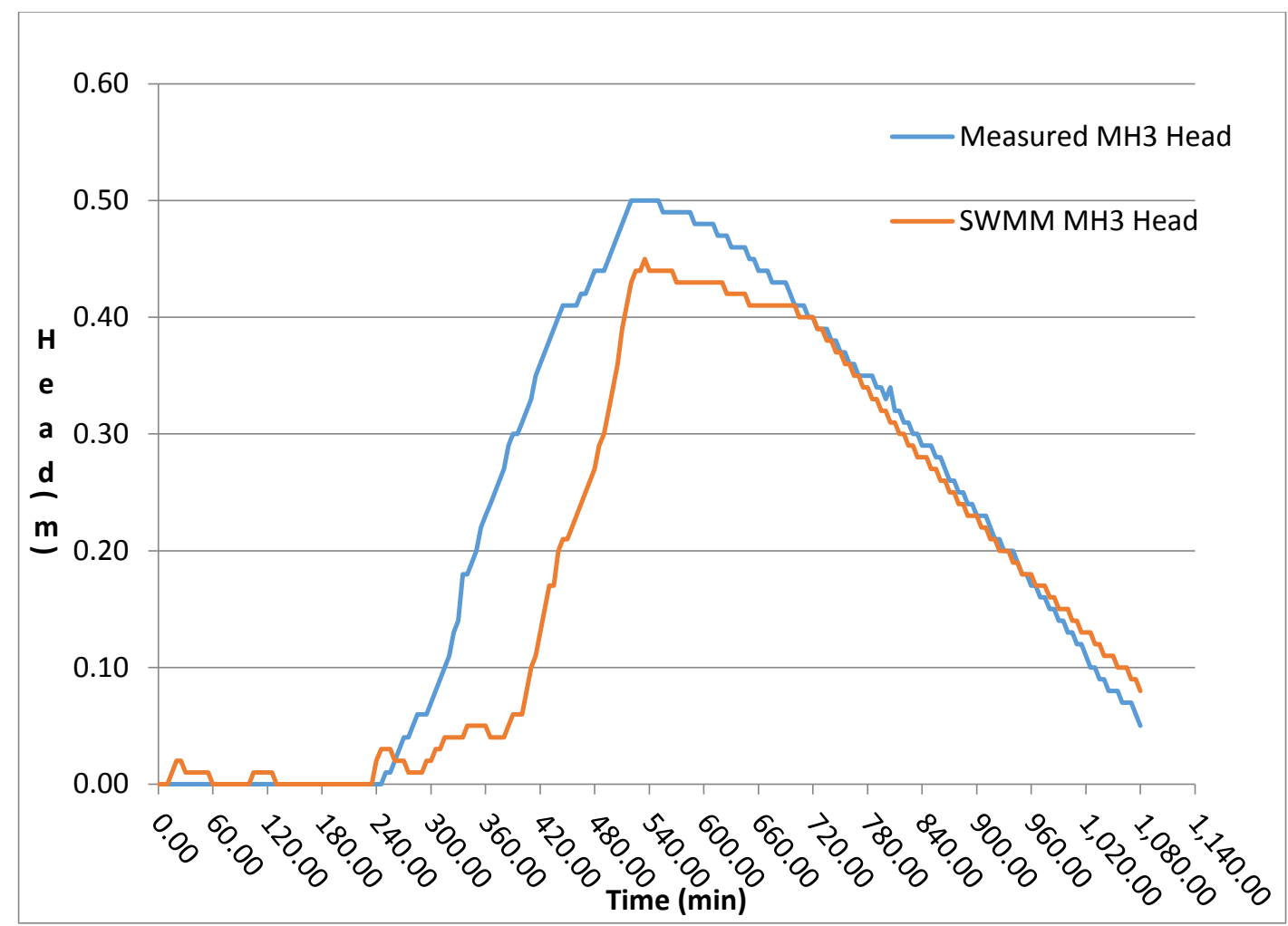

Figure $17 \mathrm{MH}_{3}$ Head results compared with measured $\mathrm{MH}_{3} \mathrm{Head}$

From the above modelling results, it can be concluded that the Orifice-Storage-Pump method in SWMM should be used to simulate EES performance. Since SWMM is a continuous simulation model, it can be used to simulate long-term average performance of EES. In the next Chapter, this modelling approach was applied to simulate the stormwater performance of EES at a case study site in the Town of Richmond Hill. 


\section{Chapter 4 Case Study}

\subsection{Site Description}

According to Toronto and Region Conservation Authority for the Living City, the watershed of GTA is divided into 8 regions (Humber River, Rouge River, Etobicoke \& Mimico Creek, Duffins\& Carruthers Creeds, Highland Creek, Don River, Petticoat Creek, and Lake Ontario Water front watershed). The selected site for this research is located at the south-east of Bayview Avenue and Elgin Mills Road, in the Town of Richmond Hill within the Rouge River region as shown in Figures 18 and 19.

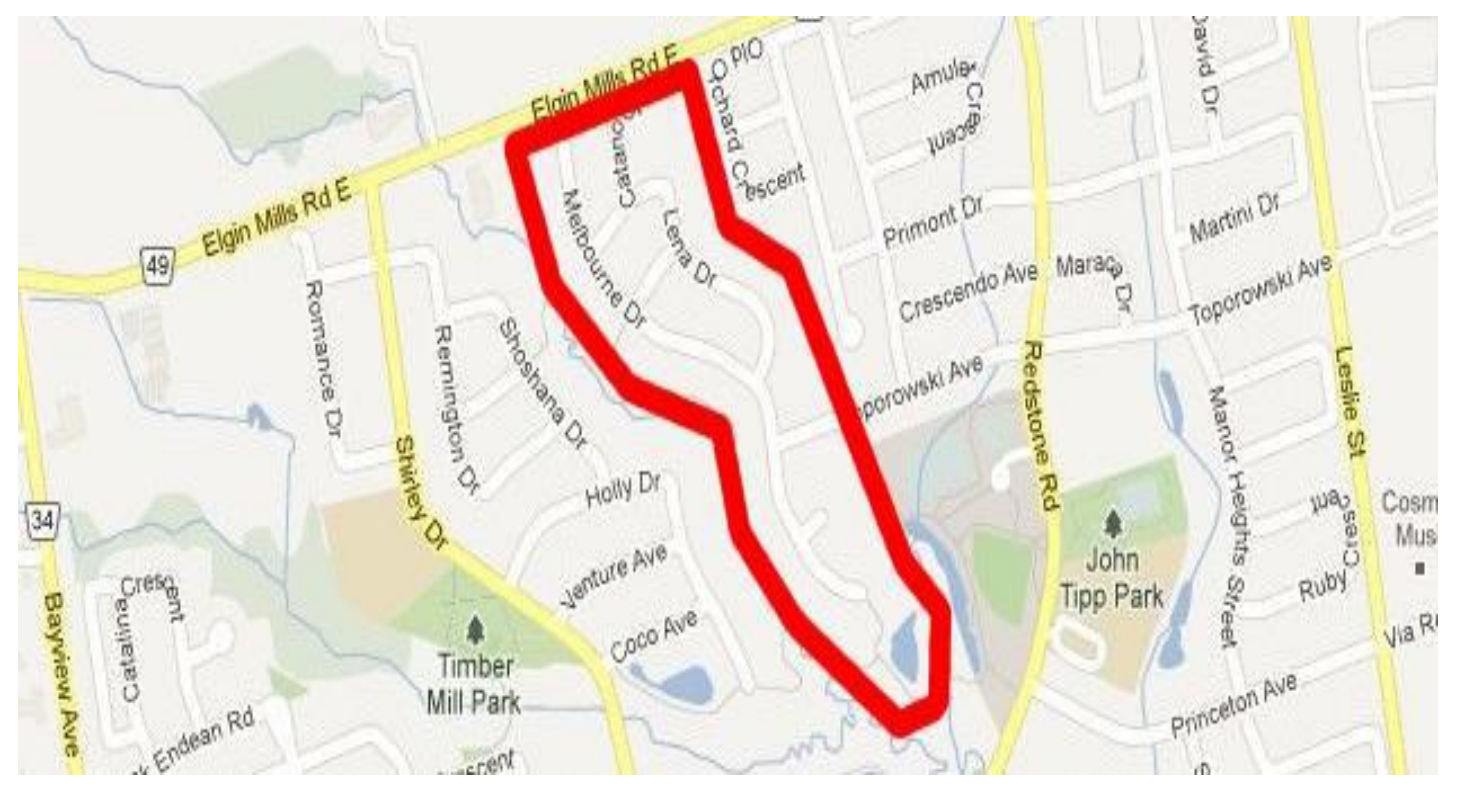

Figure 18 Map outlining the location of the subcatchment within the Town of Richmond Hill 


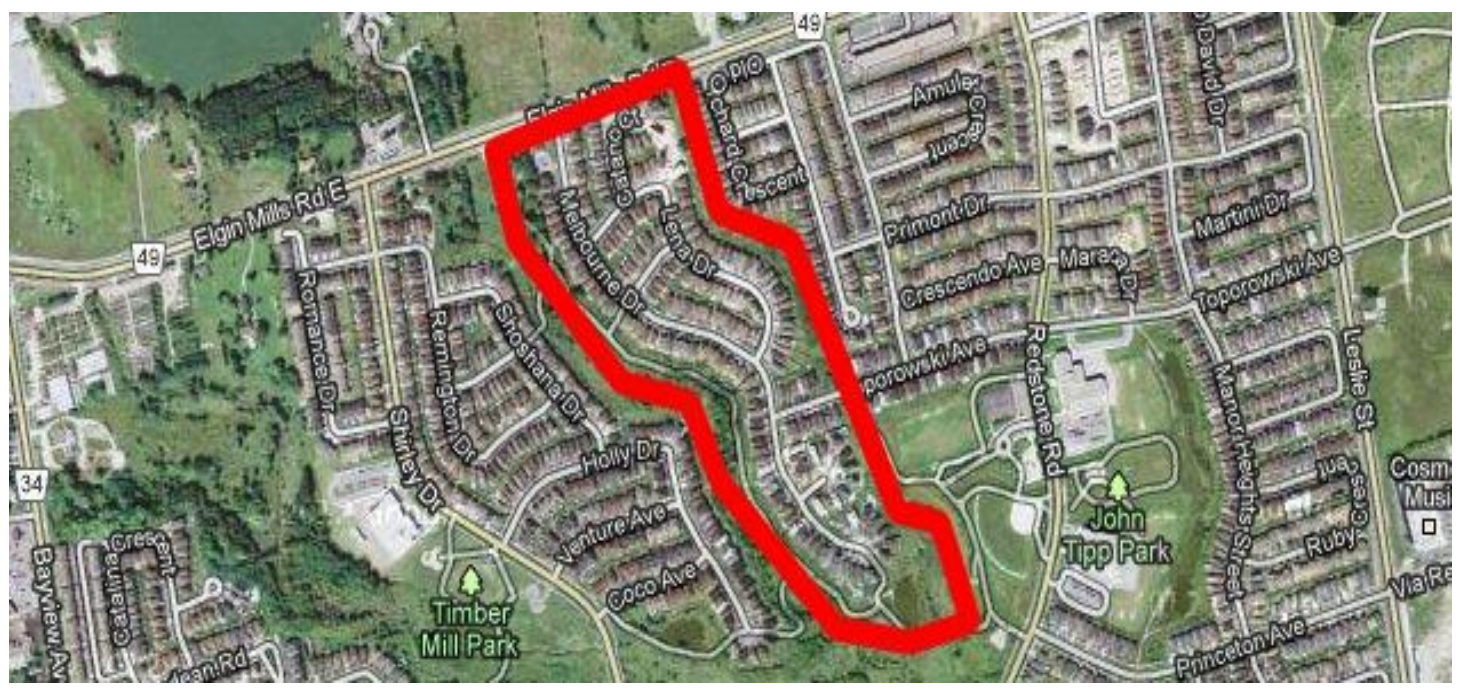

Figure 19 A satellite picture showing the terrain and drainage area of the subcatchment

There are two main zones within the Rouge River considering the contiguous and uniform climate: the Lake Ontario shore zone and the South Slope. The selected area is in the range of the South Slope zone, with relatively higher topography and less influence from Lake Ontario. The mean annual temperature of the portion of the South Slope zone is approximately $7^{\circ} \mathrm{C}$ (Sanderson, 2004). During summer, high air temperatures usually reach the mid to upper $20^{\circ} \mathrm{C}$ but several special days reach the low and mid $30^{\circ} \mathrm{C}$. However, winter temperatures vary a lot from daytime to midnight. An incursion of warm air from the south that pushes a January day up over $10^{\circ} \mathrm{C}$ can easily be followed by an Arctic air mass and overnight lows below $-25^{\circ} \mathrm{C}$ (Toronto and Region Conservation, 2007). Thus, the stormwater management design in this area should consider the variation of temperatures during winter. The selected site, which is in the Peel Plain region, consists of sandy loam and other fineparticle fraction and is relatively flat. According to the soil condition, soil characteristics can be chosen from Table 14 . The site is relatively flat with a $2 \%$ slope. Following the existing site grade, the stormwater runoff flows to the southeast of the site where the pond is located. 
Table 14 Soil characteristics (Rossman, 2008)

\begin{tabular}{|c|c|c|c|c|c|}
\hline Soil Texture Class & $\begin{array}{c}\text { K (saturated } \\
\text { hydraulic } \\
\text { conductivity, } \\
\text { mm/hr) }\end{array}$ & $\begin{array}{c}\mathbf{\Psi} \\
\text { (suction } \\
\text { head, } \\
\text { mm) }\end{array}$ & $\begin{array}{c}\mathbf{\Phi} \\
\text { (porosity, } \\
\text { fraction) }\end{array}$ & $\begin{array}{c}\text { FC (field } \\
\text { capacity, } \\
\text { fraction) }\end{array}$ & $\begin{array}{c}\text { WP } \\
\text { (wilting } \\
\text { point, } \\
\text { fraction) }\end{array}$ \\
\hline Sand & 120.40 & 49.02 & 0.437 & 0.062 & 0.024 \\
\hline Loamy Sand & 29.97 & 60.96 & 0.437 & 0.105 & 0.047 \\
\hline Sandy Loam & 10.92 & 109.98 & 0.453 & 0.190 & 0.085 \\
\hline Loam & 3.30 & 88.9 & 0.463 & 0.232 & 0.116 \\
\hline Silt Loam & 6.60 & 169.93 & 0.501 & 0.284 & 0.135 \\
\hline Sandy Clay Loam & 1.52 & 219.96 & 0.398 & 0.244 & 0.136 \\
\hline Clay Loam & 1.02 & 210.06 & 0.464 & 0.310 & 0.187 \\
\hline Silty Clay Loam & 1.02 & 270.00 & 0.471 & 0.342 & 0.210 \\
\hline Sandy Clay & 0.51 & 240.03 & 0.430 & 0.321 & 0.221 \\
\hline Silty Clay & 0.51 & 290.07 & 0.479 & 0.371 & 0.251 \\
\hline Clay & 0.25 & 320.04 & 0.475 & 0.378 & 0.265 \\
\hline
\end{tabular}

The existing wet pond drains a residential subcatchment area of 10.45 hectares with a design volume of $4786 \mathrm{~m}^{3}$. The wet pond was designed for an advanced protection level with $80 \%$ SS removal efficiency as shown in Table 5 in Chapter 2. For wet pond, TSS is related to the impervious area. Edward (1996) did a water quality study in the Metropolitan Toronto Area and the results shows that the TSS AEMCs (Annual Event Mean Concentrations) is 179.52mg/L for a residential area with some commercial (Edwards, 1996).

\subsection{Storm Sewer Network}

\subsubsection{Subcatchment Parameters}

The watershed is divided into 31 sub drainage areas according to the Design \& Construction legend provided by Engineering \& Public Works of Richmond Hill, as shown in Figure 20. (Town of Richmond Hill, 2008) 


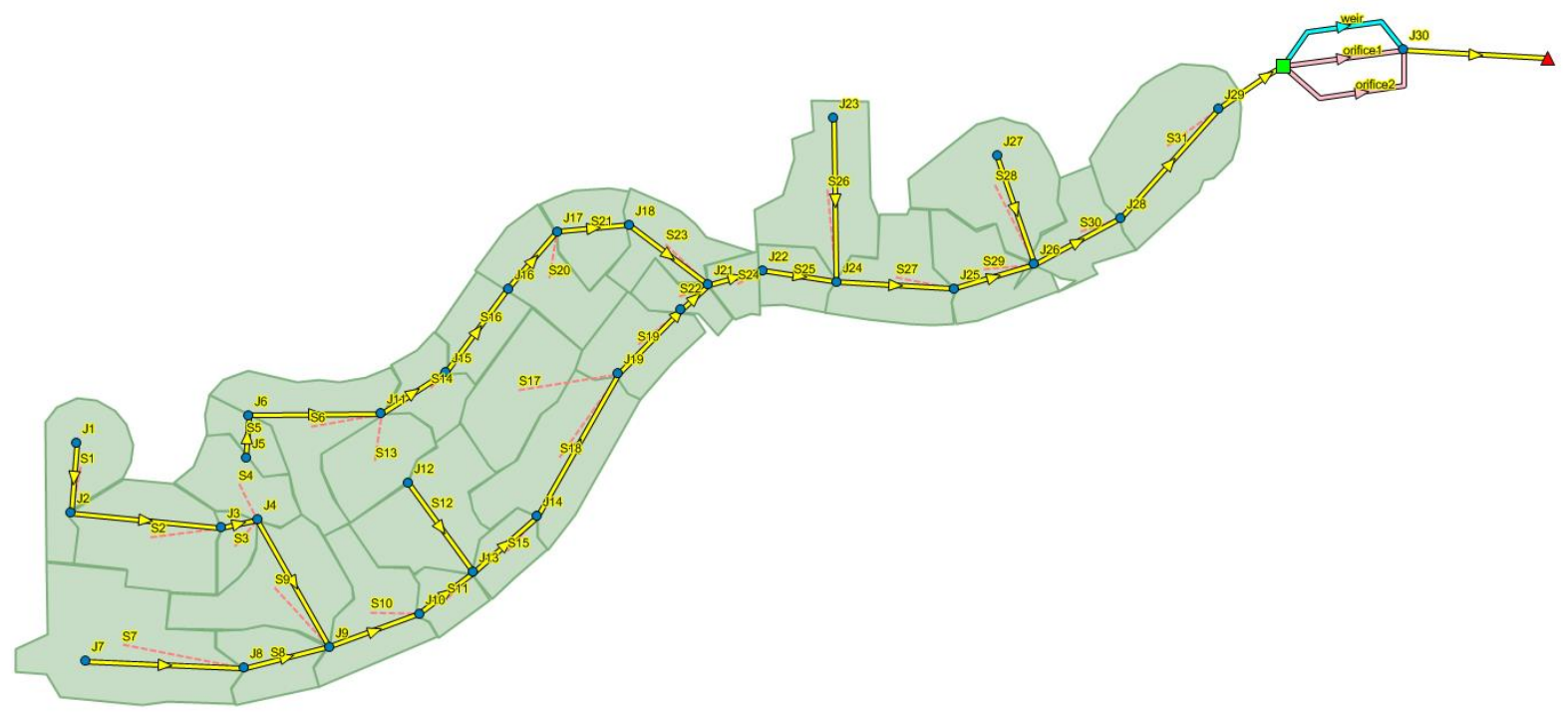

Figure 20 Study area storm sewer network

The area of each subcatchment and curb length could be measured in Google Earth. \% Zero Imperv' in SWMM represents the percent of impervious area with no depression storage including roads, sidewalks and driveways. '\%Imperv' in SWMM is defined by all impervious surfaces including roofs as downspouts have been disconnected from the storm sewers. By measuring area of impervious area with no depression storage and impervious surfaces, ‘\%Zero’ and ‘\%Imperv’ were calculated.

The width of subcatchment could be calculated using the following equation after measuring longest flow length of each area:

Width $(\mathrm{m})=\frac{\text { Area of Subcatchment }(\text { ha }) \times 10000}{\text { longest flow length }(\mathrm{m})}(\mathrm{Eq} 4.1)$

As the primary soil type within the drainage area is sandy loam, suction head, conductivity and initial deficit parameters can be obtained from soil characteristics given in Table 14. Depth of depression storage on impervious and pervious area, can be retrieved from the 
Richard's wet pond model (Richard, 2013). Parameters of subcatchments are displayed in Appendix A.

\subsubsection{Storm Sewer Design}

The storm sewer was designed in accordance with the Richmond Hill Standards and Specifications Manual.

\subsubsection{Water Quantity}

Runoff peak flow is estimated using the Rational Formula:

$$
\mathrm{Q}_{\mathrm{q}}=\frac{\text { Air }}{360}(\mathrm{Eq} 4.2)
$$

Where,

$\mathrm{Q}_{\mathrm{q}}=$ the runoff quantity, $\mathrm{m}^{3} / \mathrm{s}$;

A =drainage area, ha;

$\mathrm{i}=$ average rainfall intensity, $\mathrm{mm} / \mathrm{hr}$;

$r=$ runoff coefficient.

The drainage area is obtained in the previous step. The land use type of this area is single family residential, so the runoff coefficient is 0.45(Town of Richmond Hill, 1998). The 5-yr rainfall intensity is calculated as follows:

$\mathrm{i}=991 \times(\mathrm{T}+4)^{\wedge}(-0.808)(\mathrm{Eq} 4.3)$

Where,

$\mathrm{T}=$ time of concentration, $(\mathrm{min})$. 


\subsubsection{Sewer Pipe Capacity}

The capacity of storm sewers is computed using the Manning equation:

$\mathrm{Q}=\frac{1 \times \mathrm{R}^{\frac{2}{3}} \times \mathrm{S}^{\frac{1}{2}} \times \mathrm{A}}{\mathrm{n}}(\mathrm{Eq} 4.4)$

And

$\mathrm{V}=\frac{1 \times \mathrm{R}^{\frac{2}{3}} \times \mathrm{S}^{\frac{1}{2}}}{\mathrm{n}}(\mathrm{Eq} 4.5)$

Where,

$\mathrm{Q}=$ flow, $\mathrm{m}^{3} / \mathrm{s}$

$\mathrm{A}=$ nominal cross-section area of the sewer, $\mathrm{m}^{2}$;

$\mathrm{R}=$ hydraulic radius, $\mathrm{m}$;

$\mathrm{S}=$ slope of sewer, $\mathrm{m} / \mathrm{m}$;

$\mathrm{n}=$ roughness coefficient, for concrete pipe, $\mathrm{n}=0.013$;

$\mathrm{v}=$ velocity, $\mathrm{m} / \mathrm{s}$.

Hydraulic radius can be calculated using the following equation, in which $\mathrm{P}_{\mathrm{w}}(\mathrm{m})$ and $\mathrm{A}_{\mathrm{w}}\left(\mathrm{m}^{2}\right)$ are the wetted perimeter and area of the pipe:

$\mathrm{R}=\frac{\mathrm{Pw}}{\mathrm{Aw}}(\mathrm{Eq}$ 4.6)

Slope of the sewer is based on the topography of the area. For concrete pipes, the roughness coefficient is assumed to be 0.013 . The size of pipes should be adapted until the velocity is in the range of $0.85-5 \mathrm{~m} / \mathrm{s}$. According to the Concrete Pipe Design Manual, the pipe size could be chosen from Table 15. Also the minimum size for sewer mains should range from $0.3 \mathrm{~m}$ to 
$0.9 \mathrm{~m}$. The size of sewers can be altered until the pipe capacity is larger than the peak runoff. The parameters of sewers are shown in Appendix B.

Table 15 Pipe size and thickness (Ontario Concrete Pipe Association (OCPA), 1997)

\begin{tabular}{|l|r|r|r|r|r|r|r|r|}
\hline Pipe size (m), d & 0.3 & 0.375 & 0.45 & 0.525 & 0.6 & 0.675 & 0.75 & 0.825 \\
\hline Thickness (mm), a & 44 & 47 & 57 & 69 & 94 & 100 & 107 & 113 \\
\hline
\end{tabular}

\subsubsection{Junction Design}

The inlet elevation of the wet pond was determined to be $213.5 \mathrm{~m}$ from Richard's wet pond model (Richard, 2013). The last sewer of the sewer system C29 has a downstream elevation (213.5m); therefore Equation 4.7 is used to calculate the upstream junction elevation. In this way, all the junctions' elevations could be calculated.

Upstream elevation $=$ Downstream elevation + Slope $*$ Length of Pipe $(\mathrm{Eq} 4.7)$

The sewers' inlet elevation should be $0.85 \mathrm{~m}(0.2 \mathrm{~m}+0.35 \mathrm{~m}+0.3 \mathrm{~m})$ higher than the junction's bottom elevation. Trench elevation was assumed to be the junction elevation.

Junction depth is difference between Junction bottom and Junction ground elevation. The ground elevations are determined from the 1-meter elevation contour lines for the Regional Municipality of York (Open Data, 2011).

\subsubsection{Storm Sewer Network Sensitivity Analysis and Calibration}

The August 24-27, 2007 rainfall event was chosen for sensitivity analysis. Sensitivity analysis (i.e. the percent change of the pond head) was performed using nine parameters in the storm sewer network system. Although the model parameters are typically tested within a range of $\pm 25 \%$ of the designed values (James, 2005), this study used a range of $\pm 50 \%$ for the 
storm sewer network sensitivity analysis. A summary of the sensitivity analysis was shown in Figure 21.

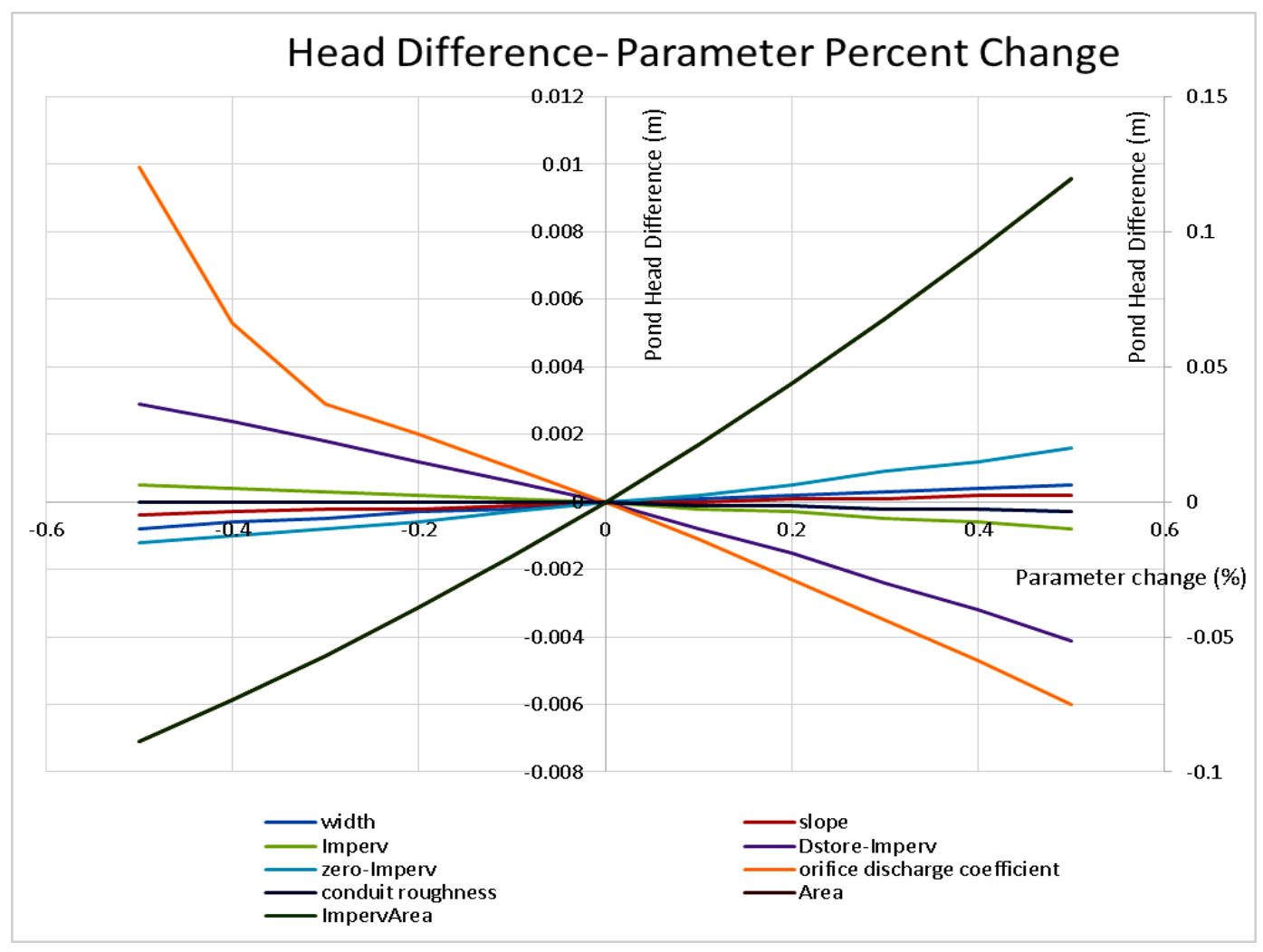

Figure 21 Head difference - percent change in parameter

Among all the tested parameters, the subcatchment area and impervious area overlapped and had more significant effect than others. These two parameters were represented with the same percent change on the right side head difference axis, while all the other parameters were represented on the middle head difference axis. From Figure 21, these parameters tested were not very sensitive parameters for the whole system.

Four storms were chosen to calibrate the storm sewer system: August 24-27, 2007 rainfall event; October 6-9, 2007 rainfall event; October 24-27, 2008 rainfall event; and May 9-12, 2009 rainfall event. The calibration results are shown in Appendix E. At the beginning of 
these four 3-day events, wet pond head was about $213.45 \mathrm{~m}$. After the simulation, the wet pond head ended around $213.5 \mathrm{~m}$ after 3 days.

\subsection{Design of EES at the Case Study Area}

Using the Planning and Design Manual of the Etobicoke Exfiltration System for Stormwater Management (Tran \& Li, 2015), the EES was designed at the case study site. EES should not be applied in the first and the last trenches of the storm sewer network. Every sewer trench is different because the storm sewer size increases from upstream to downstream end of the network. Trench design of the trench effective dimension and exfiltration rate is described below.

\section{Effective Trench Dimension}

Trench gradient was assumed to be the same as that of the storm sewer. Trench length was equal to the length of storm sewer. Trench height and width were calculated using Equation 4.8 and 4.9 based on the Candara's (1997) cross-section diagram (Figure 3) and City of Etobicoke Works Department (City of Etobicoke, 1992).

Trench Height $=0.3+0.35+2 * a+d+0.3=(d+2 a+1.15) m(E q 4.8)$

Trench Width $=2 *\left[0.5 \mathrm{~m}+\frac{0.2}{2} \mathrm{~m}+0.25 \mathrm{~m}\right]+\mathrm{dm}+2 * \mathrm{a} \mathrm{m}=(\mathrm{d}+2 \mathrm{a}+1.7) \mathrm{m}(\mathrm{Eq} 4.9)$

In which 'a' (mm) is the thickness of concrete pipes add' $(\mathrm{m})$ is the diameter of the pipes. Thickness of concrete pipes could be determined from Table 16 (Ontario Concrete Pipe Association (OCPA), 1997). However, the thickness of perforated pipes could be neglected because of the relatively small sizes. 
Table 16 Trench design parameters

\begin{tabular}{|l|l|}
\hline Height above concrete pipe & $0.3 \mathrm{~m}$ \\
\hline Perforated pipe diameter & $0.2 \mathrm{~m}$ \\
\hline Distance between inverts of concrete pipe and perforate pipe & $0.35 \mathrm{~m}$ \\
\hline Depth below perforated pipe & $0.3 \mathrm{~m}$ \\
\hline Distance between trench boundary and middle of perforated pipe & $0.5 \mathrm{~m}$ \\
\hline Distance between closest edges of perforated pipe and concrete pipe & $0.25 \mathrm{~m}$ \\
\hline
\end{tabular}

Storage area was related to the depth of trench given by Area $=\mathrm{A} \times \mathrm{Depth}^{\mathrm{B}}+\mathrm{C}$. Coefficient A and B were both given as 0 in SWMM. The $\mathrm{C}$ value of the storage was the effective area of the trench:

$\mathrm{C}=40 \% * \mathrm{~W} * \mathrm{~L}(\mathrm{Eq} 4.10)$

Where,

$\mathrm{W}=$ width of the trench, $\mathrm{m}$;

$\mathrm{L}=$ length of the trench, $\mathrm{m}$.

Parameters of storage are shown in Appendix C.

Exfiltration rate (Pump curve)

As the soil type was sandy loam, the hydraulic conductivity was $10.4 \mathrm{~mm} / \mathrm{hr}$ as shown in

Table 14. The exfiltration rate was calculated using Equation 3.2.

In the following analysis, the PCSWMM commercial software based on SWMM model) was used. The EES was modelled using Orifice-Storage-Pump method.

\subsubsection{Rainfall Data Analysis}

Rainfall data was based on a rainfall station with comprehensive records located close to the study area. The original data was processed to generate continuous rainfall data for the project. Climatic data were sourced from the National Archive System, Meteorological 
Service of Canada. Among the 271 gauge stations with hourly precipitation and temperature records in Ontario, 7 stations have records of more than 45 years of selected gauge station information (Table 17). TONRONTO gauge and TORONTO LESTER B. PERSON INT'L A gauge was nearer to the study area compared with other gauges. Although TORONTO gauge station had 65 years' rainfall data recorded, however, the mean observation on count of this gauge was less than TORONTO LESTER B. PERSON INT'L A. Therefore, in order to include more valid values, rainfall and temperature data were collected from TORONTO LESTER B. PERSON INT'L A gauge station with Climate ID 6158733 from 1960 to 2013.

Table 17 Selected gauge station information

\begin{tabular}{|c|c|c|c|c|c|c|c|}
\hline & Location Name & $\begin{array}{c}\text { Climate } \\
\text { ID }\end{array}$ & $\begin{array}{c}\text { Year } \\
\text { Count }\end{array}$ & $\begin{array}{c}\text { Earlies } \\
\text { t Year }\end{array}$ & $\begin{array}{c}\text { Most } \\
\text { Recent } \\
\text { Year }\end{array}$ & $\begin{array}{c}\text { Mean } \\
\text { Obser } \\
\text { vation } \\
\text { Count }\end{array}$ & $\begin{array}{c}\text { Distance } \\
\text { From } \\
\text { Study } \\
\text { Area }(\mathrm{km})\end{array}$ \\
\hline $\begin{array}{c}\text { HLY } \\
03\end{array}$ & SAULT STE MARIE A & 6057592 & 47 & 1961 & 2007 & 6084 & 493.78 \\
\hline $\begin{array}{c}\text { HLY } \\
\text { 03 }\end{array}$ & $\begin{array}{c}\text { KINGSTON PUMPING } \\
\text { STATION }\end{array}$ & 6104175 & 47 & 1960 & 2007 & 5677 & 237.37 \\
\hline $\begin{array}{c}\text { HLY } \\
03\end{array}$ & WINDSOR A & 6139525 & 48 & 1960 & 2007 & 7418 & 340.36 \\
\hline $\begin{array}{c}\text { HLY } \\
03\end{array}$ & $\begin{array}{c}\text { FERGUS SHAND } \\
\text { DAM }\end{array}$ & 6142400 & 48 & 1960 & 2007 & 5316 & 76.67 \\
\hline $\begin{array}{c}\text { HLY } \\
03\end{array}$ & TORONTO & 6158350 & 65 & 1937 & 2002 & 6266 & 24.41 \\
\hline $\begin{array}{c}\text { HLY } \\
03\end{array}$ & $\begin{array}{c}\text { TORONTO LESTER B. } \\
\text { PEARSON INTL A }\end{array}$ & 6158733 & 54 & 1960 & 2013 & 7227 & 29.61 \\
\hline $\begin{array}{c}\text { HLY } \\
03\end{array}$ & TRENTON A & 6158875 & 50 & 1964 & 2014 & 6836 & 152.35 \\
\hline
\end{tabular}

The record rainfall data had some un-valued data such as M-99999, M000000, and -99999 as well as some missing data. In order to select continuous rainfall days with the least missing or un-valued data, the rainfall data were processed by following the steps in Figure 22. After counting the number of Valued days and Non-Valued days in each year, the years were 
arranged in descending total record numbers of days, as shown in Appendix F F1 in Appendix F shows the rainfall data for the whole year, from which precipitation concentrated from April to October in the GTA. Therefore the rainfall data from April to October were analyzed the same way as the whole year data as shown in Appendix F2. From the results in Appendix F2, the years 2004, 2005 and 2013 were removed from the continuous rainfall data. In this way, the percentage of valued rainfall data was more than $86 \%$ in the selected continuous years.

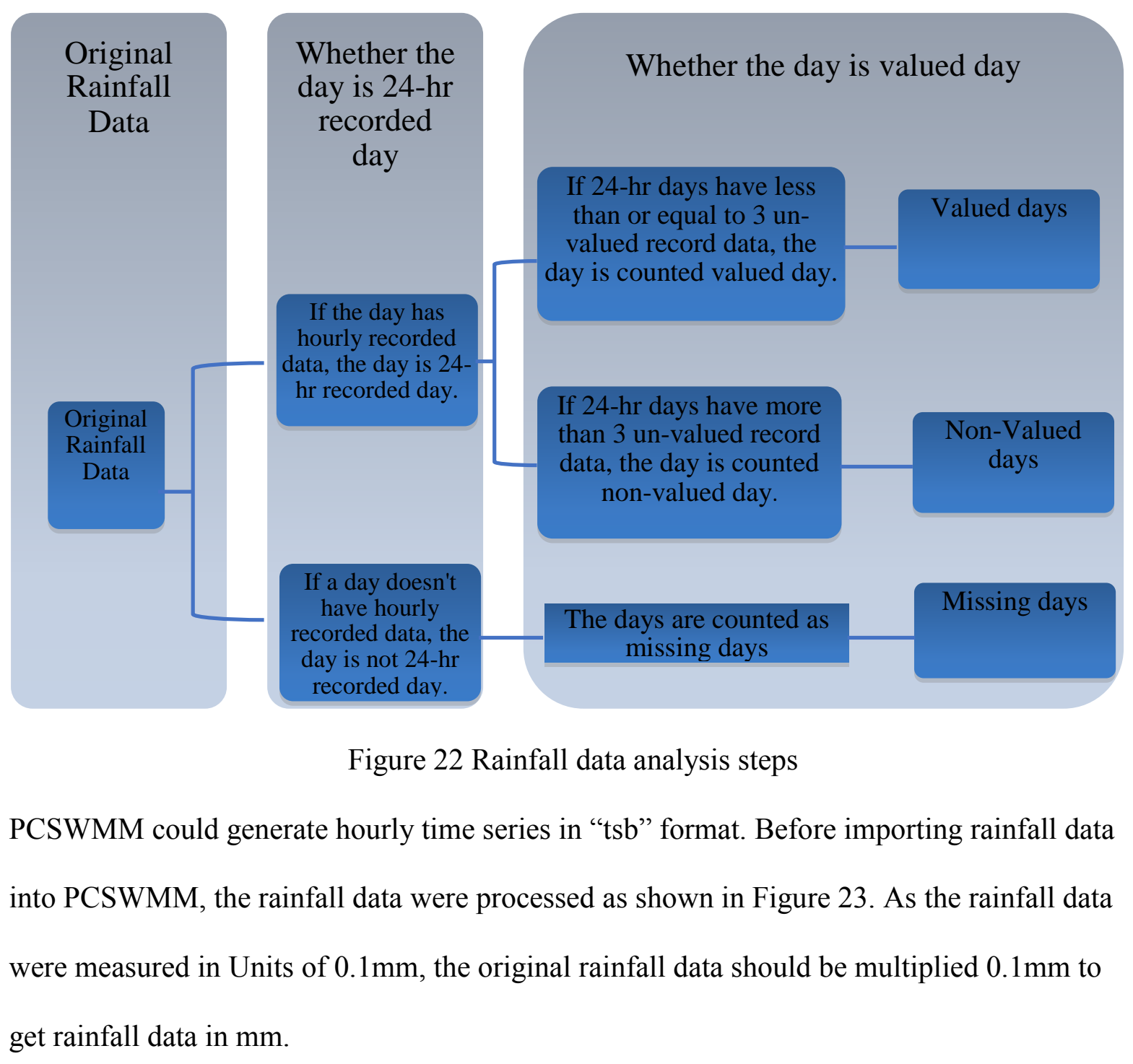




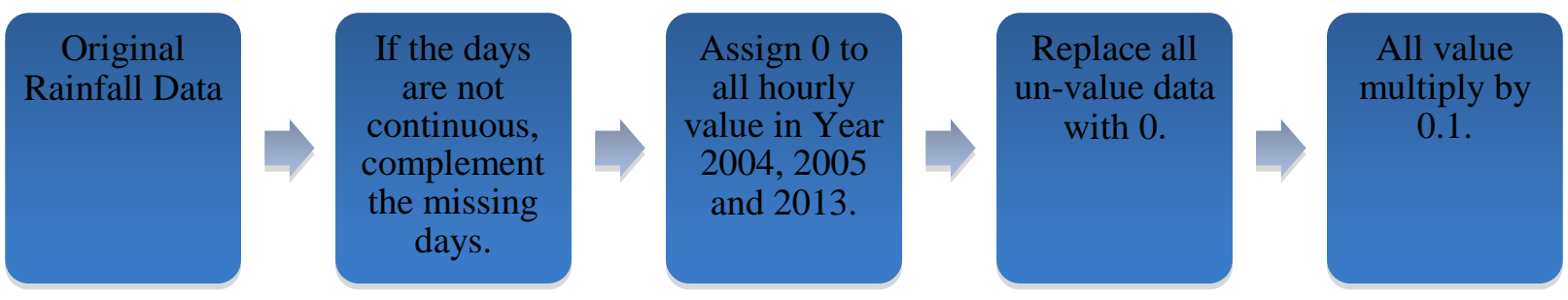

Figure 23 Rainfall data process steps

\subsubsection{Temperature Data Analysis}

Temperature data were relatively easier to process compared with rainfall data. The same station, TORONTO LESTER B. PEARSON IN'L A, was chosen for the study area. The Climate ID was6158733 with 61 years counted from 1953 to 2013, which covered all the rainfall years shown in Table 18.

Table 18 Selected gauge station information

\begin{tabular}{|c|c|c|c|c|c|c|c|}
\hline $\begin{array}{c}\text { Progr } \\
\text { am } \\
\text { Sourc } \\
\text { e }\end{array}$ & Location Name & $\begin{array}{c}\text { Climate } \\
\text { ID }\end{array}$ & $\begin{array}{c}\text { Year } \\
\text { Count }\end{array}$ & $\begin{array}{c}\text { Earliest } \\
\text { Year }\end{array}$ & $\begin{array}{c}\text { Most } \\
\text { Recent } \\
\text { Year }\end{array}$ & $\begin{array}{c}\text { Mean } \\
\text { Observatio } \\
\text { n Count }\end{array}$ & $\begin{array}{c}\text { Distance } \\
\text { From } \\
\text { Study } \\
\text { Area (km) }\end{array}$ \\
\hline $\begin{array}{c}\text { HLY } \\
01\end{array}$ & $\begin{array}{c}\text { TORONTO LESTER } \\
\text { B. PEARSON INT'L A }\end{array}$ & 6158733 & 61 & 1953 & 2013 & 8684 & 29.61 \\
\hline
\end{tabular}

The temperature was in the Daily Record of Hourly Data (HLY) standard format as shown in

Figure 24

(http://climate.weather.gc.ca/prods_servs/documentation_index_e.html\#recordFormats). The

Station Identification (STN ID) Number was 6158733 and the Element (ELEM) Number 
was78. The Value was 24-hour record temperature data and the Flag should be in alphanumeric type "F".

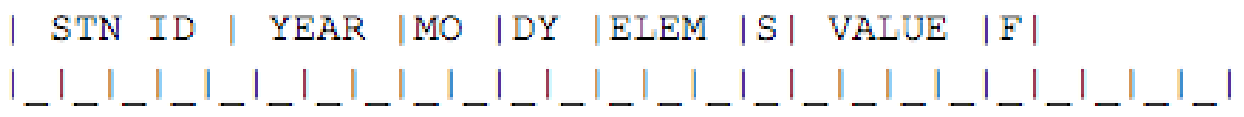

Figure 24 Temperature record format

\subsection{EES-Wet Pond System Sensitivity Analysis}

System sensitivity analysis was conducted to test how the system parameters (including subcatchment parameters and EES parameters) impacted on the system performance. A typical rainfall year for Toronto (i.e. 1992) was used as the input rainfall data.

The tested parameters were set at $100 \%$ uncertainty in PCSWMM, varying within a range of $\pm 25 \%$ of the designed values. Designed values can be varied in Sensitivity-based Radio Tuning Calibration Tool of radio tuning and then the maximum head; wet pond inflow and wet pond outflow (flow from orifices) can be received directly. As well, the water balance can be gained by calculating percentage of runoff, infiltration and evaporation.

Sensitivity analysis charts of wet pond head, wet pond inflow and outflow are shown in Appendices $\mathrm{G}$ and $\mathrm{H}$. Compared to all the other parameters that do not impact significantly on the wet pond head, soil conductivity of the trench impact significantly on the wet pond head. For runoff volumes flowing into the wet pond, orifices parameters are very sensitive. Water balance does not change a lot during the analysis, which indicates the tested parameters are all not sensitive parameters. 


\subsection{Summary of case study}

In this case study, storm sewer design was first conducted in the study area. After calibration by four selected storms, EES was designed for each trench and then applied in SWMM. Fifty years' rainfall data was analyzed for the continuous simulation.

In order to investigate the stormwater performance of the combined EES-Wet Pond System at a case study site in Richmond Hill, a typical rainfall year for Toronto (i.e. 1992) was used as the input data in SWMM. For the one year simulation, the peak flow can be reduced $41.9 \%$ from $328.6 \mathrm{~L} / \mathrm{s}$ to $190.7 \mathrm{~L} / \mathrm{s}$. Total inflow of wet pond is reduced $79 \%$ from $20380 \mathrm{~m}^{3}$ to $4088 \mathrm{~m}^{3} ; 9 \%$ of the precipitation is evaporated; and $44 \%$ becomes surface runoff. EES system increases the hydrologic losses of the hydrologic cycle by converting $15 \%$ of precipitation, which becomes surface runoff in system without EES, to exfiltration. 


\section{Chapter 5 Analysis of Results}

As explained in Chapter 1, the main purpose of this research was to investigate how EES impacts water quantity, water quality and water balance in the case study area. By applying EES before the wet pond in the case study area, the impact of EES on the performance of the wet pond can be determined. PCSWMM was used to simulate the EES performance from 1960 to 2013.

\subsection{Stormwater Quantity}

Since the wet pond in the study area is a flood control detention pond, its ability to reduce water volume is limited. By applying the combination system of wet pond and EES, the stormwater runoff was reduced $9855\left(\mathrm{~m}^{3} / \mathrm{yr}\right)$, which is about $77 \%$ of the runoff quantity without EES.

As shown in Figures 25 and 26, the runoff inflow to the wet pond indicates a peak flow lag after applying EES before the wet pond. These two figures were part of the total inflow hydrograph to the wet pond over 53 years of rainfall simulations. 


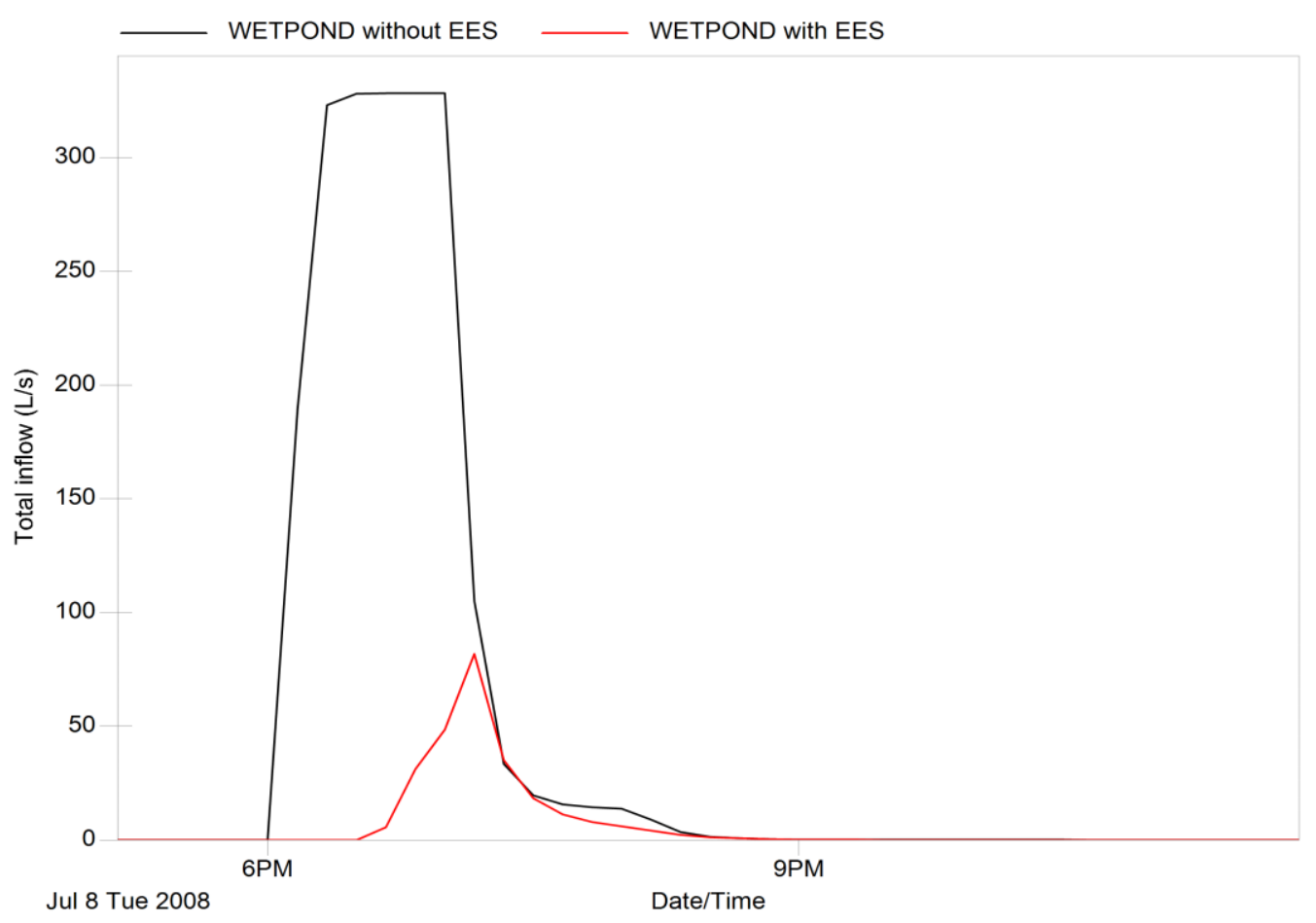

Figure 25 Wet pond total inflow hydrograph 1

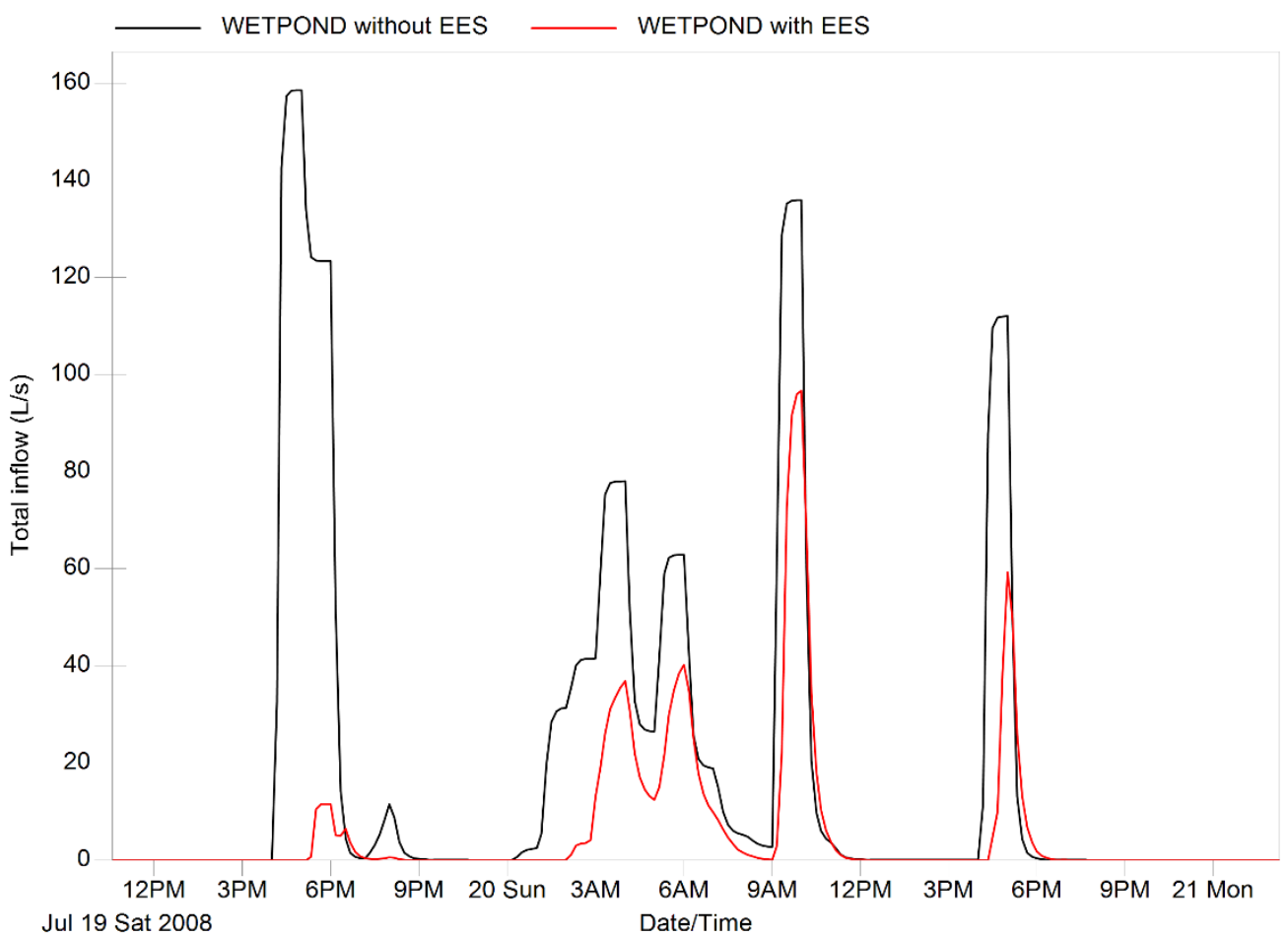

Figure 26 Wet pond total inflow hydrograph 2 
The total inflow and outflow duration graphs of the wet pond with and without EES are shown in Figure 27. The duration of inflow and outflow are taken log in order to make it easier to recognize the curves. The inflow and outflow duration curves with EES move to left; therefore, the occurrence time of certain flow will reduce.

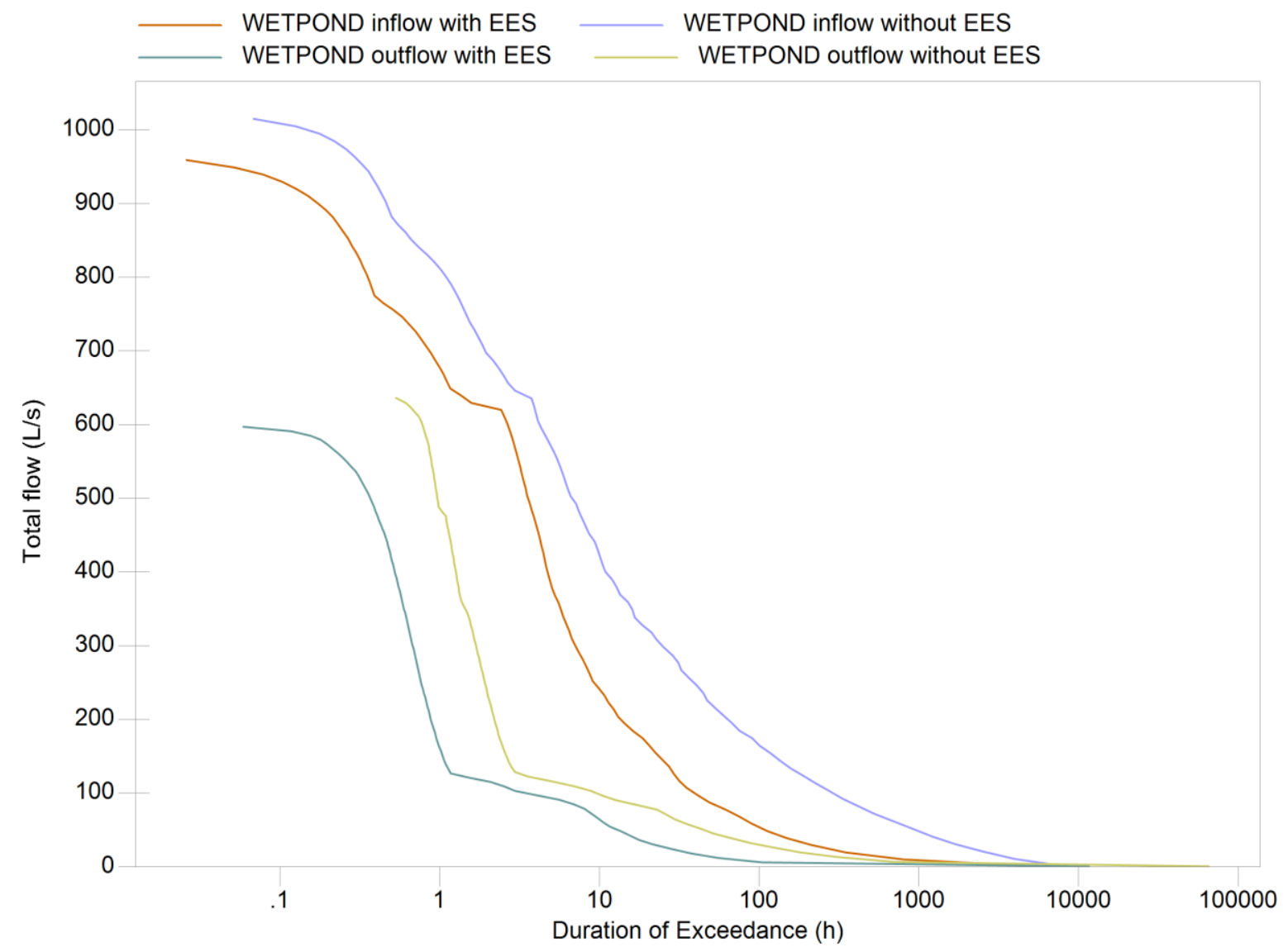

Figure 27 Flow duration curve

\subsection{Water Balance}

Figure 28 shows the predevelopment water balance, which is based on the assumption that the subcatchment impervious area and zero impervious area were set as 0 . Other parameters in predevelopment model are the same as the parameters in development model. The impervious area and zero impervious area percentage were changed after development. In 
SWMM, the Hargreaves method to calculate the evaporation rate. (Hargreaves \& Z.A., 1985) Since the soil is sandy loam, the rain will percolate faster and evaporation rate is low. Therefore, total infiltration is much more than total evaporation. After urbanization, there will be more impervious area where evaporation rate will be higher than that of the sandy loam pervious area before development.

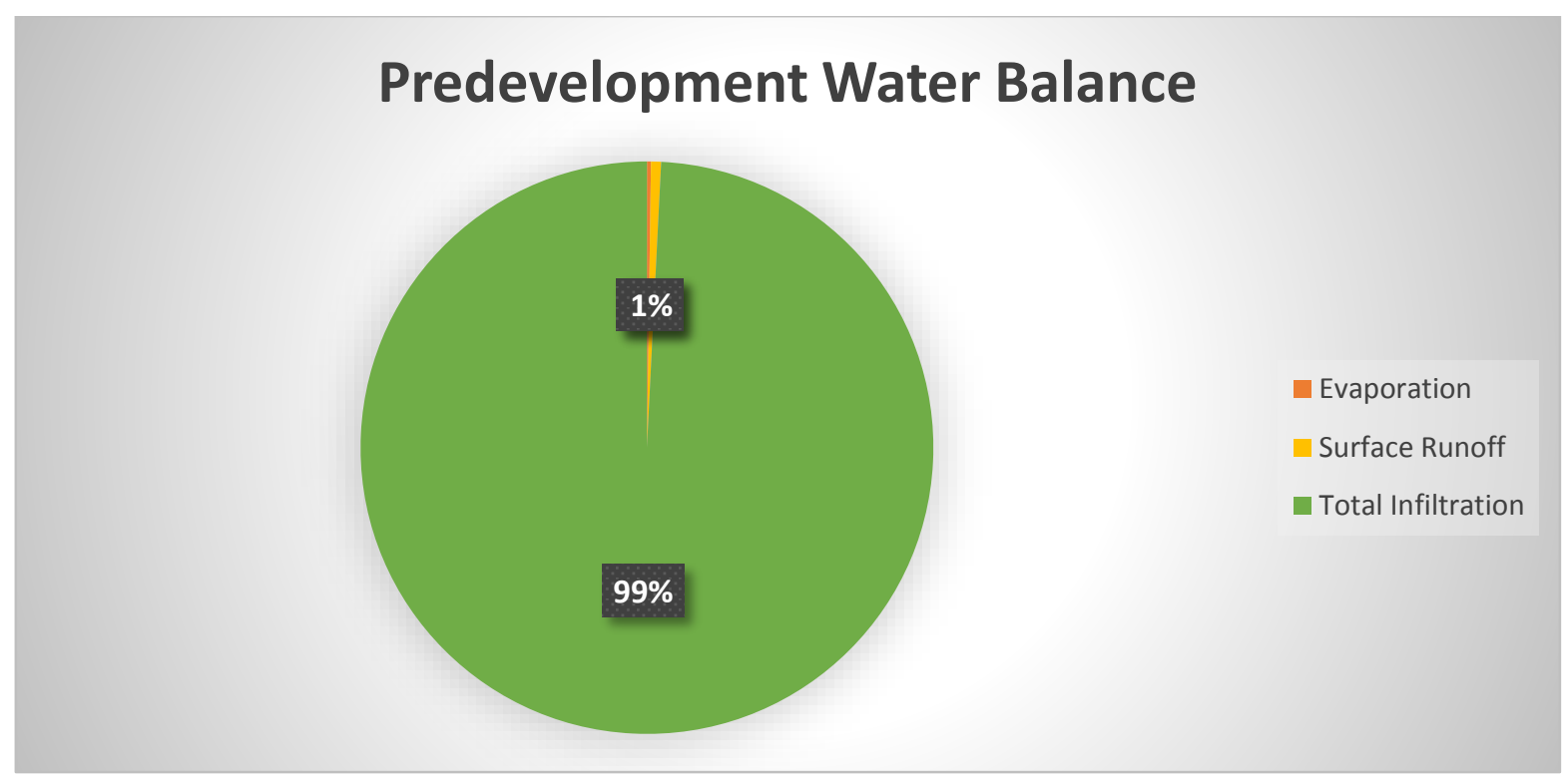

Figure 28 Predevelopment water balance

Water balance of the case study site after development with only wet pond is shown in Figure 29. In this condition, $54 \%$ of the precipitation was infiltrated, $18 \%$ was evaporated and $28 \%$ became surface runoff. 


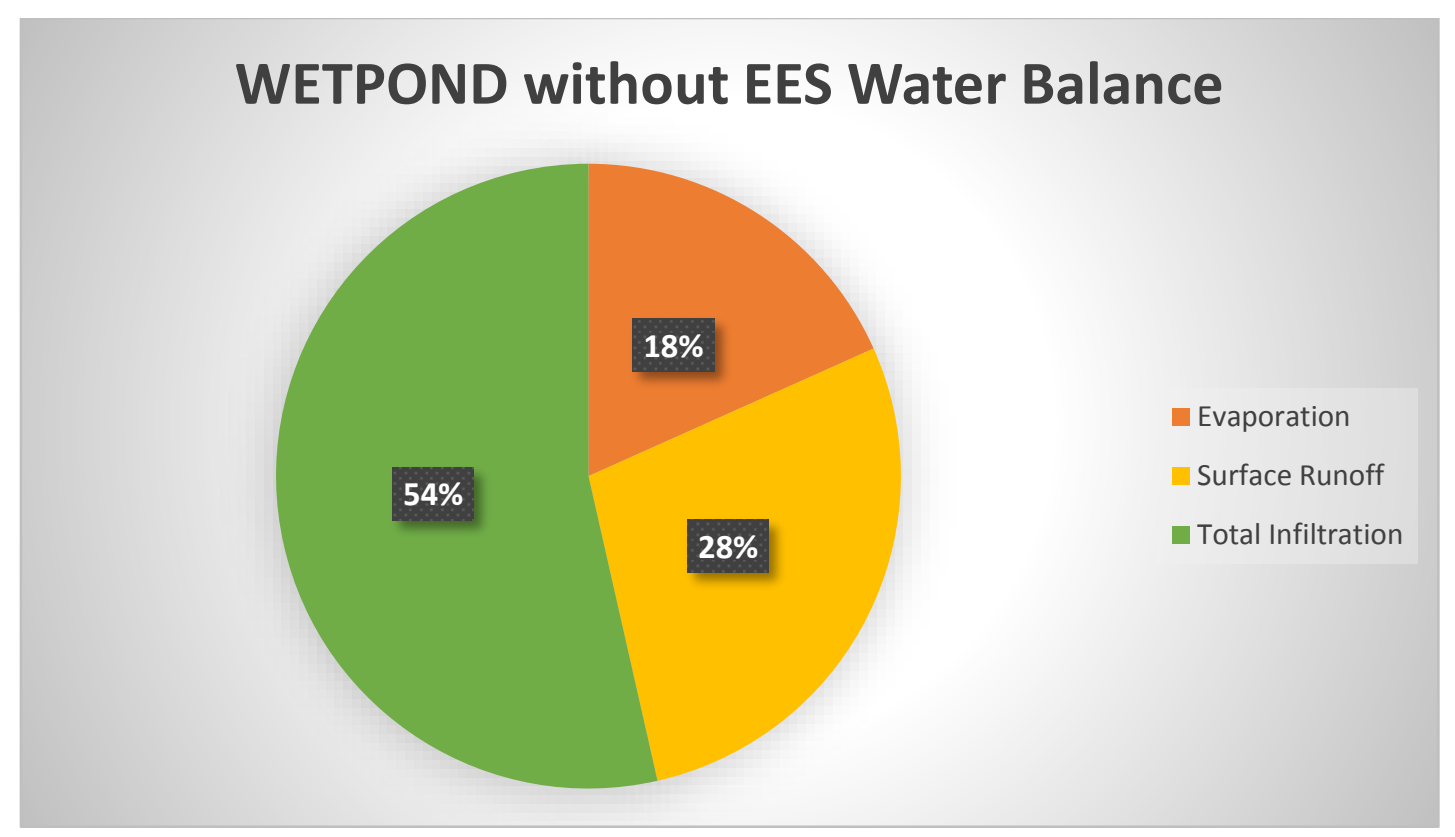

Figure 29 Wet pond without EES water balance

Water balance of the urbanized case study site with wet pond and EES is shown in Figure 30.

By applying EES before wet pond, evaporation didn't change. However, infiltration was improved from $54 \%$ to $76 \%$, which consisted of two parts: one part was the catchment infiltration (54\%) and the other was the exfiltration of EES (22\%). Moreover, surface runoff was reduced to $6 \%$. After applying EES $22 \%$ of precipitation was changed from surface runoff to exfiltration. 


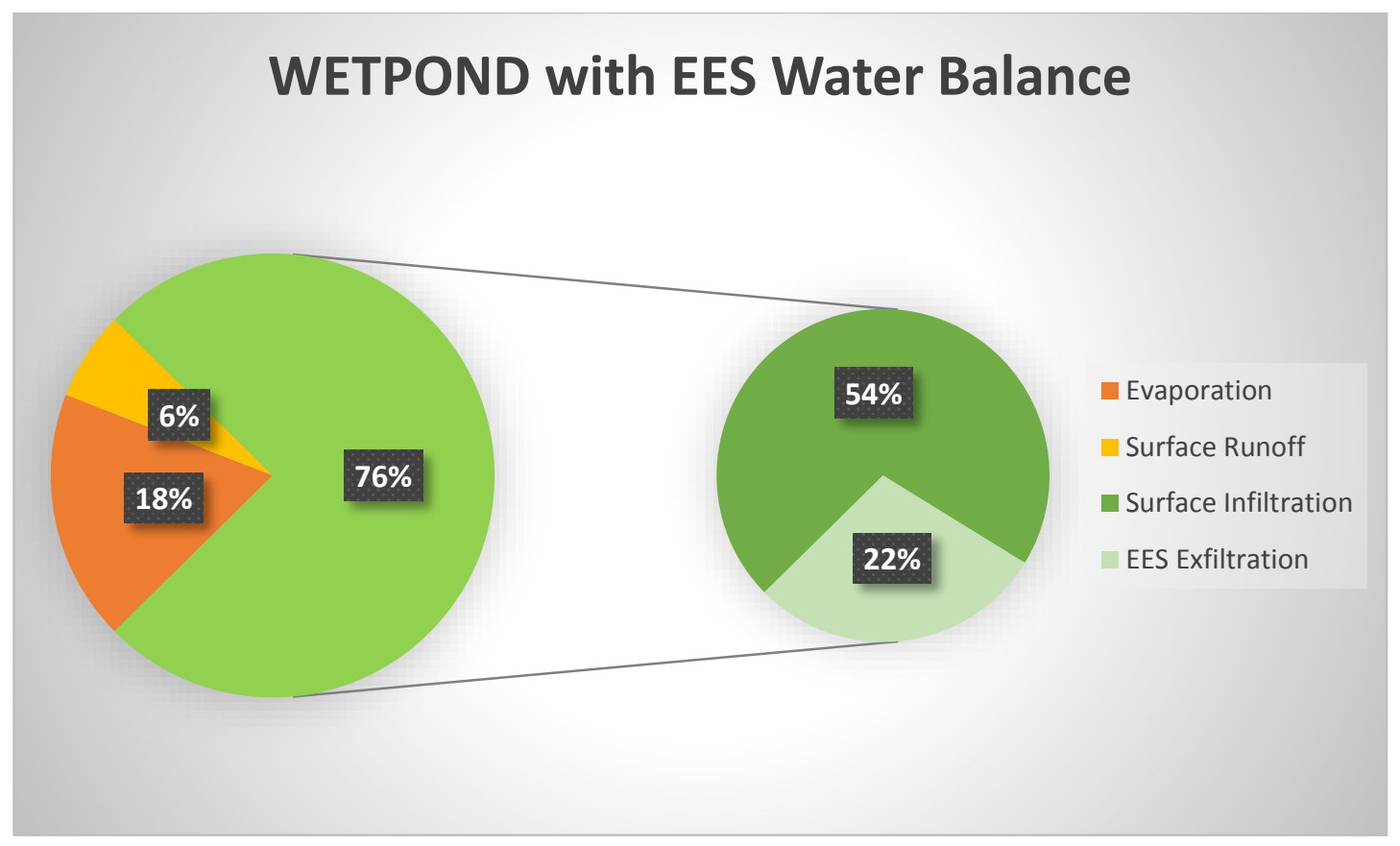

Figure 30 Wet pond with EES water balance

\subsection{Stormwater Quality}

As previously mentioned, the TSS AEMCs was $179 \mathrm{mg} / \mathrm{L}$ for a residential area with some commercial in the Toronto area. Also, the TSS removal for advanced protection level wet pond should be $80 \%$ (Ministry of Environment (MOE), 2003). The wet pond at the case study site without EES (Figure 31) could achieve 80\% TSS removal frequency based on the simulation.

The total runoff in the calculation of water quality is $12831 \mathrm{~m}^{3} / \mathrm{yr}$ (the sum of overflow from weir and outflow from orifices) was only $0.03 \%$ different from the reported $12827 \mathrm{~m}^{3} / \mathrm{yr}$. The difference may be attributed to the time step of $2 \mathrm{~s}$ in the PCSWMM model instead of reporting time step of $5 \mathrm{~min}$. In order to decrease the difference, the reporting time step could be reduced to the time step of the model. 


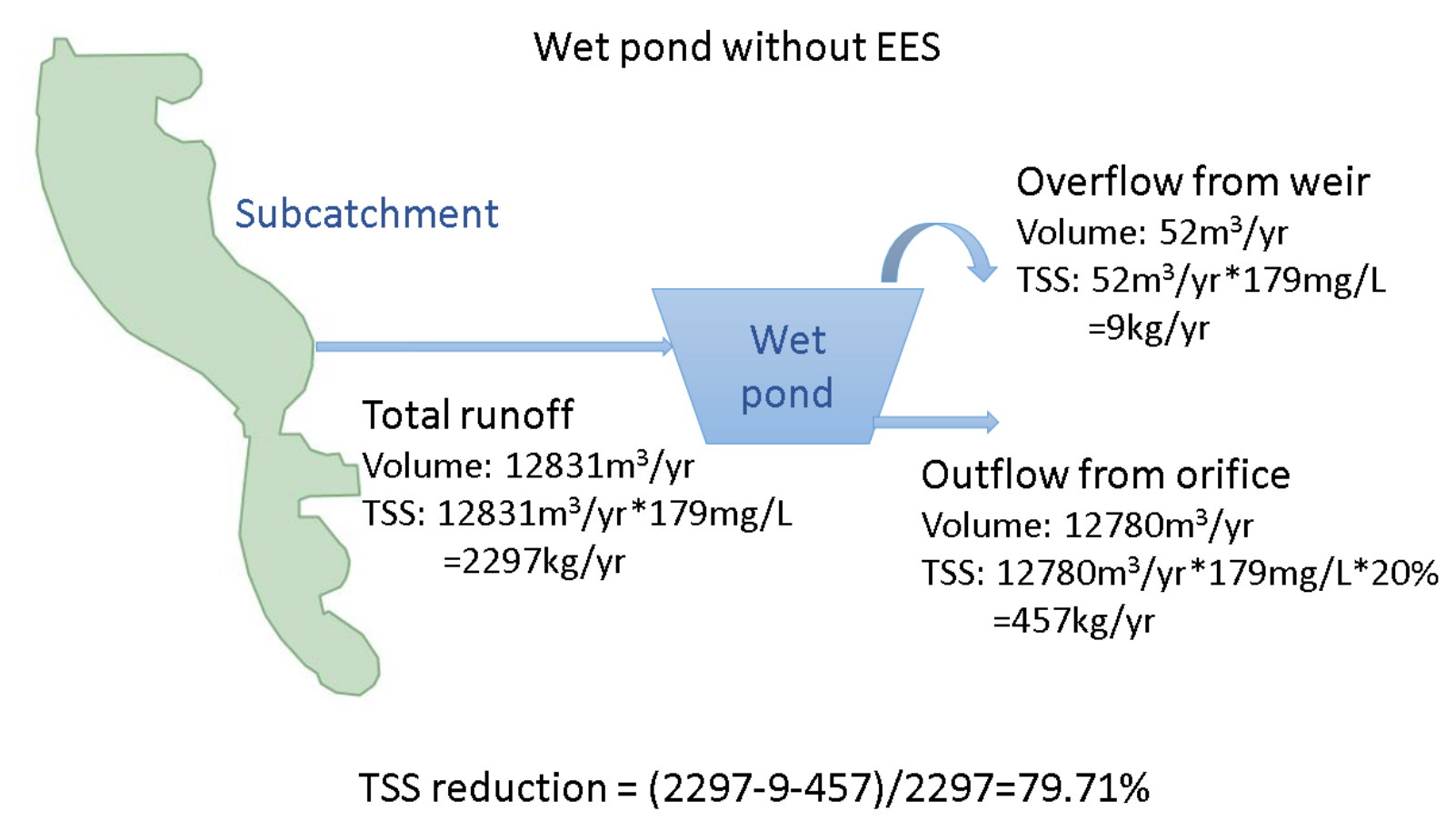

Figure 31 Wet pond without EES TSS reduction

Whereas, the TSS removal efficiency of combined EES and wet pond system could be improved up to 95\% as shown in Figure 32. In this case, a large amount of stormwater was exfiltrated through the EES. Compared with only wet pond in the study area, EES and wet pond could improve the water quality removal performance to exceed the criteria. Even without the wet pond, EES could achieve TSS reduction of about77\% in study area (Figure 33). The amount of total runoff for wet pond with EES was different from that of wet pond without EES due to the reporting time step of 5 minutes. 


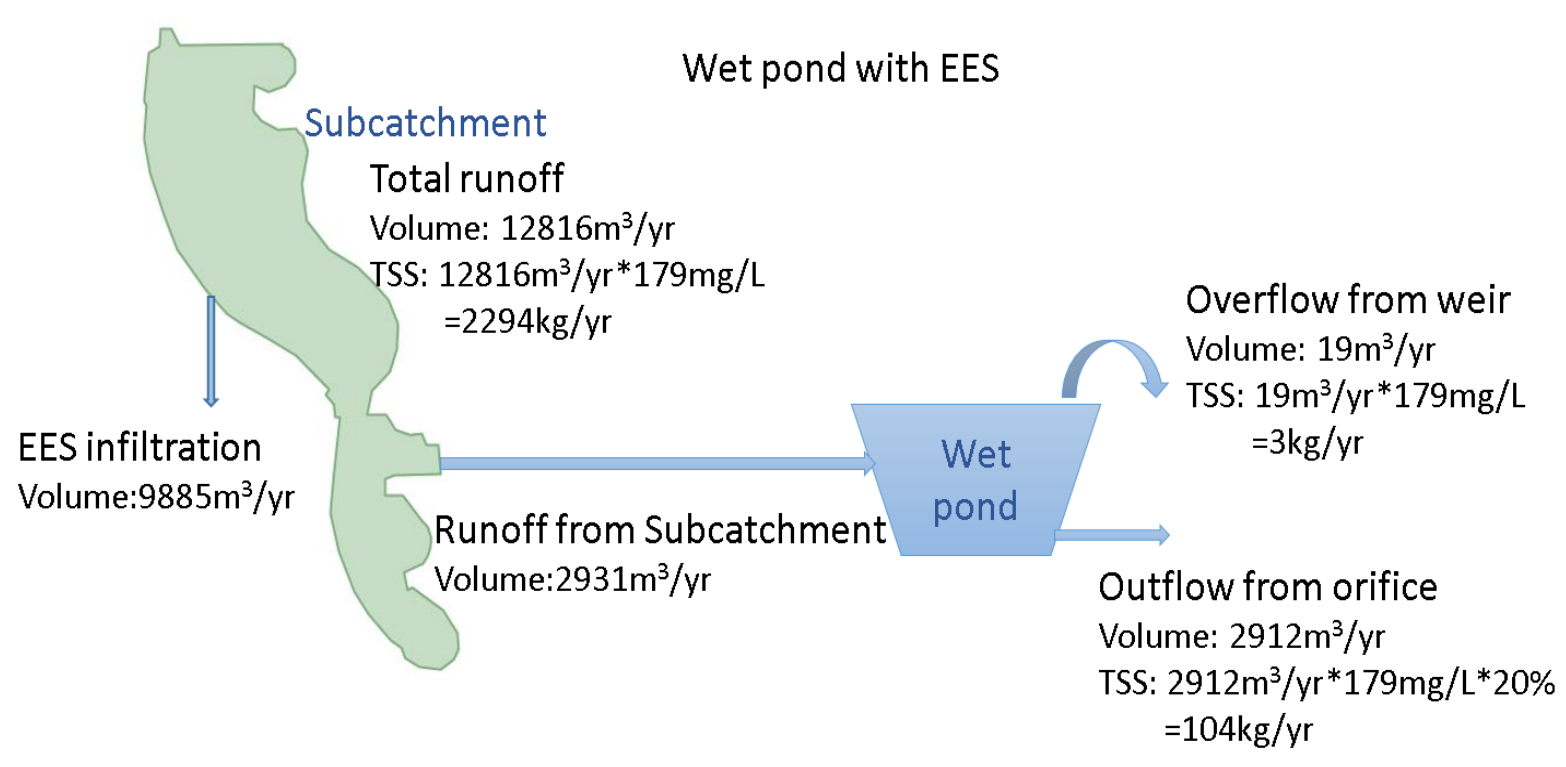

TSS reduction $=(2294-3-104) / 2294=95.33 \%$

Figure 32 Wet pond with EES TSS reduction

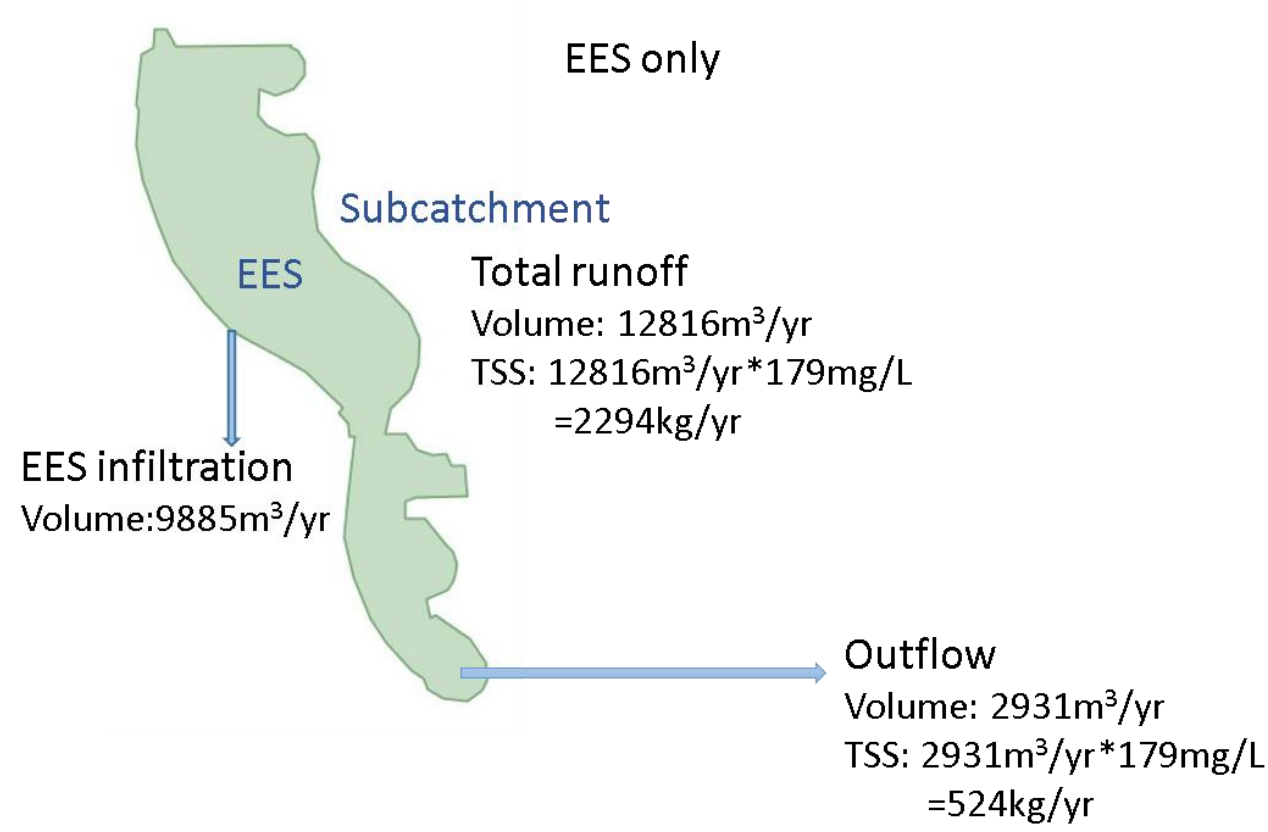

TSS reduction $=(2294-524) / 2294=77.16 \%$

Figure 33 EES only TSS reduction 


\section{Chapter 6 Conclusion and Recommendations}

\subsection{Conclusions}

This research mainly focused on modelling EES. Based on the investigation, the following conclusions are drawn.

Four modelling approaches were tested which include the MIDUSS event based model and four options in PCSWMM model. It was found that the Orifice-Pump-Storage method in PCSWMM was the best approach to model EES.

While analyzing EES performance over a single event using MIDUSS, runoff depths and maximum intensities were expressively higher than $15 \mathrm{~mm}$ and 50mm/hr (Ternier, 2012). In order to investigate the long-term performance of EES with a wet pond, a case study was conducted using the PCSWMM over 53-year rainfalls. Compared to the single event results, EES didn't perform that well for every single event throughout 53 years.

The case study also showed EES could meet the three criteria of stormwater management. The average runoff volume reduction of EES was $9885 \mathrm{~m}^{3} / \mathrm{yr}$ over 53 years, which was attributed to exfiltration. Thus $28 \%$ of precipitation was reduced to $6 \%$ and turned into exfiltration. By applying EES with wet pond, the long-term average TSS removal frequency was also improved up to $95 \%$.

\subsection{Recommendations}

In this research, EES performs as a LID practice; meeting the stormwater management criteria of water volume and water balance. However, further research is still required with regard to EES 
TSS removal mechanisms. Moreover, other pollutants should also be investigated with regard to groundwater quality protection as water exfiltrating from EES flows directly to groundwater.

Additionally, EES was applied in every trench except the first and the last one in the study area. The whole system may be optimized by the following further investigations:

- Part of the EES in the storm sewer network can be removed instead of applying EES in every trench to reduce the cost.

- The location of the EES in a storm sewer network could be investigated for optimizing.

- By applying EES, the wet pond size can be further reduced.

- Wet pond standard may be revised if combined with EES.

Finally, by comparing the cost of applying EES with the cost of maintaining wet pond, better decisions can be made about the feasibility of applying EES. 


\section{References}

A.M. Candaras Associates Inc. (1997). Post-Constructyion Evaluation of Stormwater Exfiltration \& Filtration Systems. Etobicoke,Ontario: Queen's Printer for Ontario.

Binstock, M. (2011). Greening Stormwater Management in Ontario: An Analysis of Challenges and Opportunities. Urban Ecosystems .

Bradford, A., \& Gharabaghi, B. (2004). Evolution of Ontario's Stormwater Management Planning and Design Guidance. Water Quality Resource Journal , 39 (4), 343-355.

Brown, R., Line, D., \& Hunt, W. (2012, June). LID Treatment Train: Previous Concrete with Subsurface Storage in Series with Bioretention and Care with Seasonal High Water Tables. Journal of Environmental Engineering , 689-697.

Center for Watershed Protection. (1998). Better Site Design: A Handbook for Changing Development Rules in Your Community. Ellicott City, Maryland.

Chapman, L., \& Putman, D. (1983). The Physiography of Southern Ontario, 3rd Edition. Ontario Geological Survery, Special Volume 2.

Chmakova, A. S. (2007). Environmental Assessment of Stormwater Pond Impact on A Rouge River Tributary. Theses and Dissertations Paper317.

City of Etobicoke. (1992). Princess Margarete Boulevard Drawing PRB-1236-9-1.

City of Los Angeles. (2011). Development Best Management Practices Handbook- Low Impact Development Manual Part B.

Credit Valley Conservation (CVC); Toronto and Region Conservation (TRCA). (2010). Low Impact Development Stormwater management Planning and Design Guide.

Damodaram, C., Giacomoni, M. H., Khedun, C. P., Holmes, H., Ryan, A., Saour, W., et al. (2010). Simulation of combined best management practices and Low Impact Development for Sustainable Stormwater Management. Journal of the American Water Resources Association (JAWRA) , 46 (5), 907-918.

Department of Environmental Resources. (1993). Design Manual For Use of Bioretention in Stormwater Management. Department of Environmental Resources, Division of Environmental Management, Watershed Protection Branch, Prince George's County, Maryland.

Dietz, M. E. (2007). Low Impact Development Practices: A Review of Current Research and Recommendations for Future Directions. Water Air Soil Pollution, 186, 351-363.

Dmodaram, C., Giacomoni, M. H., C. Prakash Khedun, H. H., Ryan, A., Saour, W., \& Zechman, E. M. (2010). Simulation of Combined Best Management Practices and Low Impact Development for Sustainable Stormwater Management. Journal of the American Water Resources Association , 46 (5), 907-918. 
Government of South Australia Adelaide. (2009). Water Sensitive Urban Design -Technical Manual.

Groffman, P. M., \& Crawford, M. K. (2003, May/June). Denitrification Potential in Urban Riparian Zones. Journal of Environmental Quality, 1144-1149.

Hargreaves, G., \& Z.A., S. (1985). Reference Crop Evapotranspiration from temperature. Applied Engineering in Agriculture, 96-99.

Hollis, G. (1975). The Effect of Urbanization on Floods of Different Recurrence Interval.

Holman-Dodds, J. K., Bradley, A. A., \& Potter, K. W. (2003, February). Evaluation of Hydrologic Benefits of Infiltration Based Urban Stormwater Management. Journal of the American Water Resources Association , 205-215.

2008Hydrologic Bioretention Performance and Design Criteria For Cold Climates

James, W. (2005). Rules for Responsible Modeling- 4th Edition. Guelph,Ontario: CHI .

Johengen, T. H., \& LaRock, P. A. (1993). Quantifying nutrient removal processes within a constucted wetland designed to treat urban stormwater runoff. Ecological Engineering , 347-366.

Khowaja, Z. A. (2007). Development of Stormwater Exfiltration Systems. Thesis and Dissertations. Paper 255.

Mayer, T., Marsalek, J., \& Reyes, E. D. (1995). Nutrients and Metal Contaminants Status of Urban Stormwater Ponds. Journal of lake and Reservoir Management .

McCutcheon, M., \& Wride, D. (2013). Shades of Green: Using SWMM LID Controls to Simulate Green Infrastructure. Pragmatic Modeling of Urban Water Systems, Monograph 21.

1996Metropolitan Toronto Waterfront Stormwater Quality Characterization Study

Ministry of Environment (MOE). (2003). Stormwater management planning and design manual. Toronto,Ontario: Queen's Printer for Ontario.

Ministry of Environment and Climate Change. (2015, February). Interpretation Bulletin Ontario Ministry of Environment and Climate Change Expectations Re Stormwater Management.

Newcomer, M. E., Gurdak, J. J., Sklar, L. S., \& Nanus, L. (2014). Urban recharge beneath low impact development and effects of climate variability and change. Water Resources Research, pp. 1716-1734.

Oberts, G. (2000). Influence of Snowmelt Dynamics on Stormwater Runoff quality. Watershed Protection Techniques , 1 (2), 55-61.

Olding, D. D., Steele, T. S., \& Nemeth, J. C. (2004). Operational Monitoring of Urban Stormwater Management Facilities and Receiving Subwatersheds in Richmond Hill, Ontario. Water Quality Resource Journal , 39 (4), pp. 392-405.

Ontario Concrete Pipe Association (OCPA). (1997). Concrete Pipe Design Manual. 
Open Data. (2011). Retrieved from York Region: http://www.york.ca/opendatalist/

Pazwash, H. (2011). Urban Stormwater Management. Taylor and Francis Group, LLC.

Richard, R. (2013). Investigation of The Sediment Removal Frequency For Wet-detention Stormwater Management Ponds. Toronto, Ontario.

Roseen, R., Ballestero, T., Houle, J., Avelleaneda, P., Briggs, J., Fowler, G., et al. (2009). Seasonal Performance Variaations for Stormwater Management Systems in Cold Climate Conditions. Journal of Environmental Engineering , 135 (3), 128-137.

Rossman, L. A. (2008). Stormwater Management model User's Manual Version 5.0. Water Supply and Water Resources Division National Risk Managment Reaearch Laboratory, Cincinnati, ON.

Sanderson, M. (2004). Weather and Climate in Southern Ontario. University of Waterloo, Department of Geography, Waterloo.

Stormwater Assessment Monitoring and Perfomance Program. (2004). Performance Assessment of A Perforated Pipe Stormwater Exfiltration System. Toronto, ON: Toronto and Region Conservation Authority.

Ternier, S. (2012). Review of Stormwater Management In Ontario And A Case Study On the Etobicoke Exfiltration System. Thesis, Ryerson University, Environmental Applied Science and Management, Toronto, Ontario.

The Municipal Infrastructure Group Ltd.; Schollen \& Company Inc. (2011). Stormwater Management Feasibility Study. Toronto, Ontario.

Toronto and Region Conservation. (2006). Performance Evaluation of Permeable Pavement and A Bioretention Swale. Seneca College; King City, Ontario. Toronto and Region Conservartion Authority, Interim Report \#2.

Toronto and Region Conservation. (2007). Rouge River Watershed Plan Towards A Healthy And Sustainable Future. Toronto, ON.

Toronto and Region Conservation. (2012). Stormwater Management Criteria. Retrieved from http://www.trca.on.ca/the-living-city/water-flood-management/storm-water-management.dot

Town of Richmond Hill. (2008, Feburary 26). Engineering \& Public Work Design \& Construction.

Town of Richmond Hill. (1998). Richmond Hill Standards and Specifications Manual. Richmond Hill, Ontario.

Tran, J., \& Li, J. (2015). Planning and Design Manual of the Etobicoke Exfiltration System for Stormwater Management. Toronto.

Tsihrintzis, V. A., \& Hamid, R. (1997). Modeling and Management of Urban Stormwater Runoff Quality: A Review. Water Resources Management , 137-164. 
United States Environmental Protection Agency (US EPA). (2000). Low Impact Development (LID)- A Literature Review. Office of Water (4203), Washington DC.

United States Environmental Protection Agency (US EPA). (1999). Preliminary Data Summary of Urban Stormwater Best Management Practices. Office of Water.

United States Environmental Protection Agency. (2007). Reducing Stormwater Costs through Low Impact Development (LID) Strategies and Practices. Nonpoint Source Control Branch, Washington DC.

US Department of Transportation. Retention, Detention and Overland Flow for Pollutant Removal from Highway Stormwater Runoff, volume I: Research Report. U.S. Department of Transportation, Federal Highway Administration.

Villarreal, E. L., \& Bengtsson, A. S.-D. (2004). Inner City Stormwater Contorl Using A Combination of Best Management Practices. Ecological Engineering , 279-298.

Wahl, M., McKellar, H., \& Williams, T. Patterns of Nutrient Loading in Forested and Urbanized Coastal Streams. Journal of Excperimental Marine Biology and Ecology, 213, 111-131.

Wong, T. (2006). An Overview of Water Sensitive Urban Design Practices in Australia. Water Practice \& Technology, 1 (1). 


\section{Appendix A - Subcatchment Parameters}

\begin{tabular}{|c|c|c|c|c|c|c|c|c|c|c|}
\hline $\mathbf{S}$ & $\begin{array}{c}\text { Area } \\
\text { (ha) }\end{array}$ & $\begin{array}{c}\text { Width } \\
\text { (m) }\end{array}$ & $\begin{array}{c}\text { Flow } \\
\text { Length } \\
(\mathbf{m}) \\
\end{array}$ & $\begin{array}{c}\text { Imperv. } \\
(\%)\end{array}$ & $\begin{array}{c}\text { DstoreIm } \\
\text { perv } \\
(\mathbf{m m}) \\
\end{array}$ & $\begin{array}{l}\text { Dstore } \\
\text { Perv } \\
(\mathbf{m m}) \\
\end{array}$ & $\begin{array}{c}\text { Zero } \\
\text { Imper } \\
\text { v (\%) } \\
\end{array}$ & $\begin{array}{c}\text { Curb } \\
\text { Length }\end{array}$ & $\begin{array}{c}\text { Conductivit } \\
\mathbf{y}(\mathbf{m m} / \mathbf{h r})\end{array}$ & $\begin{array}{l}\text { Longest } \\
\text { path(ft) }\end{array}$ \\
\hline S1 & 0.5800 & 67.80 & 85.55 & 13.67 & 0.80 & 1.50 & 6.84 & 35.94 & 10.92 & 280.57 \\
\hline S2 & 0.3500 & 45.60 & 76.75 & 25.87 & 0.80 & 1.50 & 12.94 & 88.65 & 10.92 & 251.74 \\
\hline S3 & 0.1152 & 21.55 & 53.46 & 10.16 & 0.80 & 1.50 & 5.08 & 16.82 & 10.92 & 175.35 \\
\hline S4 & 0.3537 & 41.75 & 84.72 & 9.92 & 0.80 & 1.50 & 4.96 & 37.22 & 10.92 & 277.88 \\
\hline S5 & 0.1964 & 36.16 & 54.31 & 11.66 & 0.80 & 1.50 & 5.83 & 22.42 & 10.92 & 178.17 \\
\hline S6 & 0.4784 & 43.22 & 110.69 & 16.95 & 0.80 & 1.50 & 8.48 & 76.41 & 10.92 & 363.06 \\
\hline S7 & 0.7613 & 63.24 & 120.38 & 25.38 & 0.80 & 1.50 & 12.69 & 113.71 & 10.92 & 394.85 \\
\hline S8 & 0.3521 & 48.67 & 72.34 & 26.35 & 0.80 & 1.50 & 13.17 & 45.54 & 10.92 & 237.28 \\
\hline S9 & 0.3443 & 37.32 & 92.26 & 46.44 & 0.80 & 1.50 & 13.94 & 76.91 & 10.92 & 302.61 \\
\hline S10 & 0.4243 & 58.33 & 72.74 & 31.32 & 0.80 & 1.50 & 15.66 & 57.33 & 10.92 & 238.59 \\
\hline S11 & 0.1805 & 33.96 & 53.15 & 25.93 & 0.80 & 1.50 & 12.97 & 39.91 & 10.92 & 174.33 \\
\hline S12 & 0.3637 & 43.86 & 82.92 & 31.65 & 0.80 & 1.50 & 15.83 & 55.74 & 10.92 & 271.98 \\
\hline S13 & 0.2574 & 48.44 & 53.14 & 59.44 & 0.80 & 1.50 & 29.72 & 43.70 & 10.92 & 174.30 \\
\hline S14 & 0.1758 & 40.76 & 43.13 & 61.95 & 0.80 & 1.50 & 30.97 & 40.97 & 10.92 & 141.47 \\
\hline S15 & 0.1850 & 32.08 & 57.67 & 51.19 & 0.80 & 1.50 & 25.60 & 36.67 & 10.92 & 189.16 \\
\hline S16 & 0.2149 & 41.66 & 51.58 & 34.39 & 0.80 & 1.50 & 17.19 & 53.90 & 10.92 & 169.18 \\
\hline S17 & 0.2746 & 28.67 & 95.78 & 87.36 & 0.80 & 1.50 & 43.68 & 0.00 & 10.92 & 314.13 \\
\hline S18 & 0.6252 & 55.35 & 112.95 & 63.92 & 0.80 & 1.50 & 31.96 & 88.13 & 10.92 & 370.51 \\
\hline S19 & 0.3634 & 54.70 & 66.44 & 54.13 & 0.80 & 1.50 & 27.06 & 47.30 & 10.92 & 217.92 \\
\hline S20 & 0.3670 & 64.73 & 56.70 & 49.46 & 0.80 & 1.50 & 24.73 & 36.56 & 10.92 & 192.86 \\
\hline S21 & 0.2596 & 40.11 & 64.72 & 65.22 & 0.80 & 1.50 & 32.61 & 42.61 & 10.92 & 212.31 \\
\hline S22 & 0.1150 & 28.23 & 40.74 & 78.87 & 0.80 & 1.50 & 39.44 & 18.27 & 10.92 & 133.63 \\
\hline S23 & 0.3726 & 43.84 & 84.99 & 42.70 & 0.80 & 1.50 & 21.35 & 55.53 & 10.92 & 278.80 \\
\hline S24 & 0.0977 & 26.89 & 36.33 & 45.50 & 0.80 & 1.50 & 22.79 & 31.05 & 10.92 & 119.16 \\
\hline S25 & 0.1917 & 35.63 & 53.80 & 69.27 & 0.80 & 1.50 & 36.64 & 46.69 & 10.92 & 176.46 \\
\hline S26 & 0.3900 & 37.33 & 104.47 & 82.70 & 0.80 & 1.50 & 41.35 & 91.46 & 10.92 & 342.63 \\
\hline S27 & 0.4347 & 53.40 & 81.40 & 73.77 & 0.80 & 1.50 & 36.88 & 69.67 & 10.92 & 267.02 \\
\hline S28 & 0.4146 & 49.42 & 83.89 & 65.17 & 0.80 & 1.50 & 32.59 & 51.80 & 10.92 & 275.16 \\
\hline S29 & 0.2777 & 44.38 & 62.57 & 71.26 & 0.80 & 1.50 & 35.63 & 44.58 & 10.92 & 205.23 \\
\hline S30 & 0.2554 & 41.31 & 61.83 & 73.18 & 0.80 & 1.50 & 36.59 & 55.82 & 10.92 & 308.00 \\
\hline S31 & 0.5965 & 58.86 & 101.34 & 79.78 & 0.80 & 1.50 & 39.89 & 64.54 & 10.92 & 450.00 \\
\hline
\end{tabular}




\section{Appendix B - Sewer Parameters}

\begin{tabular}{|c|c|c|c|c|c|c|}
\hline $\begin{array}{c}\text { Sewer } \\
\text { number }\end{array}$ & $\begin{array}{l}\text { Inlet } \\
\text { Node }\end{array}$ & $\begin{array}{l}\text { Outlet } \\
\text { Node }\end{array}$ & $\begin{array}{c}\text { Geom1 } \\
(\mathrm{m})\end{array}$ & $\begin{array}{c}\text { Length } \\
\text { (m) }\end{array}$ & $\begin{array}{c}\text { Inlet } \\
\text { Offset (m) }\end{array}$ & $\begin{array}{c}\text { Outlet } \\
\text { Offset (m) }\end{array}$ \\
\hline $\mathrm{C} 1$ & $\mathrm{~J} 1$ & $\mathrm{~J} 2$ & 0.375 & 30.87 & 1.175 & 1.175 \\
\hline $\mathrm{C} 2$ & $\mathrm{~J} 2$ & $\mathrm{~J} 3$ & 0.375 & 89.07 & 1.175 & 1.175 \\
\hline $\mathrm{C3}$ & $\mathrm{J} 3$ & $\mathrm{~J} 4$ & 0.375 & 18.22 & 1.175 & 1.175 \\
\hline C4 & $\mathrm{J} 4$ & J9 & 0.45 & 78.13 & 1.1 & 1.1 \\
\hline C5 & $\mathrm{J} 7$ & $\mathrm{~J} 8$ & 0.3 & 95.76 & 1.25 & 1.25 \\
\hline C6 & J8 & J9 & 0.375 & 48.88 & 1.175 & 1.175 \\
\hline C7 & J9 & $\mathrm{J} 10$ & 0.6 & 53.5 & 0.95 & 0.95 \\
\hline $\mathrm{C} 8$ & $\mathrm{~J} 10$ & $\mathrm{~J} 13$ & 0.675 & 37.49 & 0.875 & 0.875 \\
\hline C9 & J5 & $\mathrm{J} 6$ & 0.3 & 23.76 & 1.25 & 1.25 \\
\hline $\mathrm{C} 10$ & J6 & $\mathrm{J} 11$ & 0.375 & 101.3 & 1.175 & 1.175 \\
\hline C11 & $\mathrm{J} 11$ & $\mathrm{~J} 15$ & 0.45 & 44.88 & 1.1 & 1.1 \\
\hline $\mathrm{C} 12$ & $\mathrm{~J} 15$ & $\mathrm{~J} 16$ & 0.525 & 55.84 & 1.025 & 1.025 \\
\hline C13 & $\mathrm{J} 12$ & $\mathrm{~J} 13$ & 0.375 & 58.9 & 1.175 & 1.175 \\
\hline $\mathrm{C} 14$ & $\mathrm{~J} 13$ & $\mathrm{~J} 14$ & 0.825 & 50.64 & 0.725 & 0.725 \\
\hline C15 & $\mathrm{J} 14$ & J19 & 0.825 & 89.8 & 0.725 & 0.725 \\
\hline C16 & J19 & $\mathrm{J} 20$ & 0.825 & 46.21 & 0.725 & 0.725 \\
\hline C17 & $\mathrm{J} 20$ & $\mathrm{~J} 21$ & 0.9 & 28.28 & 0.65 & 0.65 \\
\hline C18 & J16 & $\mathrm{J} 17$ & 0.525 & 43.17 & 1.025 & 1.025 \\
\hline C19 & $\mathrm{J} 17$ & $\mathrm{~J} 18$ & 0.525 & 38.52 & 1.025 & 1.025 \\
\hline $\mathrm{C20}$ & $\mathrm{J} 18$ & $\mathrm{~J} 21$ & 0.6 & 55.1 & 0.95 & 0.95 \\
\hline C21 & $\mathrm{J} 21$ & $\mathrm{~J} 22$ & 0.9 & 31.83 & 0.65 & 0.65 \\
\hline $\mathrm{C} 22$ & $\mathrm{~J} 22$ & $\mathrm{~J} 24$ & 0.9 & 46.38 & 0.65 & 0.65 \\
\hline $\mathrm{C23}$ & $\mathrm{J} 23$ & $\mathrm{~J} 24$ & 0.3 & 88.54 & 1.25 & 1.25 \\
\hline C24 & $\mathrm{J} 24$ & $\mathrm{~J} 25$ & 0.9 & 65.52 & 0.65 & 0.65 \\
\hline $\mathrm{C} 25$ & $\mathrm{~J} 25$ & $\mathrm{~J} 26$ & 0.9 & 50.16 & 0.65 & 0.65 \\
\hline $\mathrm{C} 26$ & $\mathrm{~J} 27$ & $\mathrm{~J} 26$ & 0.375 & 88.54 & 1.175 & 1.175 \\
\hline $\mathrm{C} 27$ & J26 & $\mathrm{J} 28$ & 0.9 & 54.41 & 0.65 & 0.65 \\
\hline $\mathrm{C} 28$ & $\mathrm{~J} 28$ & J29 & 0.9 & 57.99 & 0.65 & 0.65 \\
\hline C29 & J29 & WETPOND & 0.9 & 66.64 & 0.65 & 2.65 \\
\hline C30 & $\mathrm{J} 30$ & Outfall & 2 & 20 & 0 & 0 \\
\hline
\end{tabular}




\section{Appendix C - Storage Parameters}

\begin{tabular}{|c|c|c|c|c|c|c|c|}
\hline $\begin{array}{c}\text { STORAGE } \\
\text { UNIT }\end{array}$ & $\begin{array}{l}\text { Trench } \\
\text { Length, L } \\
\text { (m) }\end{array}$ & $\begin{array}{c}\text { Trench } \\
\text { Width, W } \\
\text { (m) }\end{array}$ & $\begin{array}{l}\text { Trench } \\
\text { Height, H } \\
\text { (m) }\end{array}$ & $\begin{array}{c}\text { Trench } \\
\text { effective } \\
\text { Area(C) }\end{array}$ & $\begin{array}{c}\text { Elevation } \\
\text { (m) }\end{array}$ & $\begin{array}{c}\text { Size of Pipe in } \\
\text { the trench, } d \\
(m)\end{array}$ & $\begin{array}{c}\text { thickness of } \\
\text { pipe, } a(m)\end{array}$ \\
\hline SU1 & 30.87 & 2.169 & 1.419 & 26.78 & 224.106 & 0.375 & 0.047 \\
\hline SU2 & 89.07 & 2.169 & 1.419 & 77.28 & 223.965 & 0.375 & 0.047 \\
\hline SU3 & 18.22 & 2.169 & 1.419 & 15.81 & 222.373 & 0.375 & 0.047 \\
\hline SU4 & 78.13 & 2.264 & 1.514 & 70.75 & 222.172 & 0.450 & 0.057 \\
\hline SU5 & 95.76 & 2.088 & 1.338 & 79.98 & 223.733 & 0.300 & 0.044 \\
\hline SU6 & 48.88 & 2.169 & 1.419 & 42.41 & 222.262 & 0.375 & 0.047 \\
\hline SU7 & 53.5 & 2.488 & 1.738 & 53.24 & 221.487 & 0.600 & 0.094 \\
\hline SU8 & 37.49 & 2.575 & 1.825 & 38.61 & 221.245 & 0.675 & 0.100 \\
\hline SU9 & 23.76 & 2.088 & 1.338 & 19.84 & 222.121 & 0.300 & 0.044 \\
\hline SU10 & 101.3 & 2.169 & 1.419 & 87.89 & 221.638 & 0.375 & 0.047 \\
\hline SU11 & 44.88 & 2.264 & 1.514 & 40.64 & 221.225 & 0.450 & 0.057 \\
\hline SU12 & 55.84 & 2.363 & 1.613 & 52.78 & 220.973 & 0.525 & 0.069 \\
\hline SU13 & 58.9 & 2.169 & 1.419 & 51.10 & 221.426 & 0.375 & 0.047 \\
\hline SU14 & 50.64 & 2.751 & 2.001 & 55.72 & 221.094 & 0.825 & 0.113 \\
\hline SU15 & 89.8 & 2.751 & 2.001 & 98.82 & 220.892 & 0.825 & 0.113 \\
\hline SU16 & 46.21 & 2.751 & 2.001 & 50.85 & 220.53 & 0.825 & 0.113 \\
\hline SU17 & 28.28 & 2.838 & 2.088 & 32.10 & 219.774 & 0.900 & 0.119 \\
\hline SU18 & 43.17 & 2.363 & 1.613 & 40.80 & 220.751 & 0.525 & 0.069 \\
\hline SU19 & 38.52 & 2.363 & 1.613 & 36.41 & 220.348 & 0.525 & 0.069 \\
\hline SU20 & 55.1 & 2.488 & 1.738 & 54.84 & 219.885 & 0.600 & 0.094 \\
\hline SU21 & 31.83 & 2.838 & 2.088 & 36.13 & 219.663 & 0.900 & 0.119 \\
\hline SU22 & 46.38 & 2.838 & 2.088 & 52.65 & 218.756 & 0.900 & 0.119 \\
\hline SU23 & 88.54 & 2.088 & 1.338 & 73.95 & 218.253 & 0.300 & 0.044 \\
\hline SU24 & 65.52 & 2.838 & 2.088 & 74.38 & 217.628 & 0.900 & 0.119 \\
\hline SU25 & 50.16 & 2.838 & 2.088 & 56.94 & 216.742 & 0.900 & 0.119 \\
\hline SU26 & 88.54 & 2.169 & 1.419 & 76.82 & 216.893 & 0.375 & 0.047 \\
\hline SU27 & 54.41 & 2.838 & 2.088 & 61.77 & 216.54 & 0.900 & 0.119 \\
\hline SU28 & 57.99 & 2.838 & 2.088 & 65.83 & 216.218 & 0.900 & 0.119 \\
\hline
\end{tabular}




\section{Appendix D - Junction Parameter Summary}

\begin{tabular}{|c|c|c|c|}
\hline $\begin{array}{l}\text { Junction } \\
\text { Number } \\
\end{array}$ & $\begin{array}{c}\begin{array}{c}\text { Junction } \\
\text { bottom El. } \\
(\mathbf{m})\end{array} \\
\end{array}$ & $\begin{array}{c}\text { Junction } \\
\text { ground } \\
\text { El. (m) } \\
\end{array}$ & $\begin{array}{c}\text { Junction } \\
\text { Depth (m) }\end{array}$ \\
\hline $\mathbf{J 1}$ & 224.63 & 227.36 & 2.73 \\
\hline $\mathrm{J} 2$ & 224.49 & 227.22 & 2.73 \\
\hline $\mathbf{J 3}$ & 222.90 & 225.63 & 2.73 \\
\hline $\mathrm{J} 4$ & 222.62 & 225.43 & 2.81 \\
\hline J5 & 222.72 & 225.82 & 3.10 \\
\hline $\mathrm{J} 6$ & 222.16 & 225.34 & 3.18 \\
\hline J7 & 224.33 & 226.99 & 2.66 \\
\hline J8 & 222.79 & 225.52 & 2.73 \\
\hline J9 & 221.79 & 224.75 & 2.96 \\
\hline J10 & 221.47 & 224.50 & 3.03 \\
\hline J11 & 221.68 & 224.95 & 3.27 \\
\hline $\mathrm{J} 12$ & 221.95 & 224.83 & 2.88 \\
\hline J13 & 221.22 & 224.10 & 2.88 \\
\hline J14 & 220.97 & 224.44 & 3.47 \\
\hline J15 & 221.35 & 224.70 & 3.35 \\
\hline J16 & 221.13 & 224.55 & 3.42 \\
\hline J17 & 220.72 & 224.14 & 3.42 \\
\hline $\mathrm{J18}$ & 220.19 & 223.68 & 3.49 \\
\hline J19 & 220.61 & 224.54 & 3.93 \\
\hline $\mathrm{J} 20$ & 219.77 & 223.77 & 4.00 \\
\hline $\mathrm{J} 21$ & 219.66 & 223.72 & 4.06 \\
\hline $\mathrm{J} 22$ & 218.76 & 222.82 & 4.06 \\
\hline $\mathrm{J} 23$ & 218.85 & 222.31 & 3.46 \\
\hline $\mathrm{J} 24$ & 217.63 & 221.69 & 4.06 \\
\hline $\mathrm{J} 25$ & 216.74 & 220.80 & 4.06 \\
\hline $\mathrm{J} 26$ & 216.54 & 220.60 & 4.06 \\
\hline J27 & 217.42 & 220.28 & 2.86 \\
\hline $\mathrm{J} 28$ & 216.22 & 219.60 & 3.38 \\
\hline $\mathrm{J} 29$ & 215.46 & 218.84 & 3.38 \\
\hline J30 & 213.07 & 213.07 & 0.00 \\
\hline
\end{tabular}




\section{Appendix E - Stormwater Quantity Model: Calibration Charts}

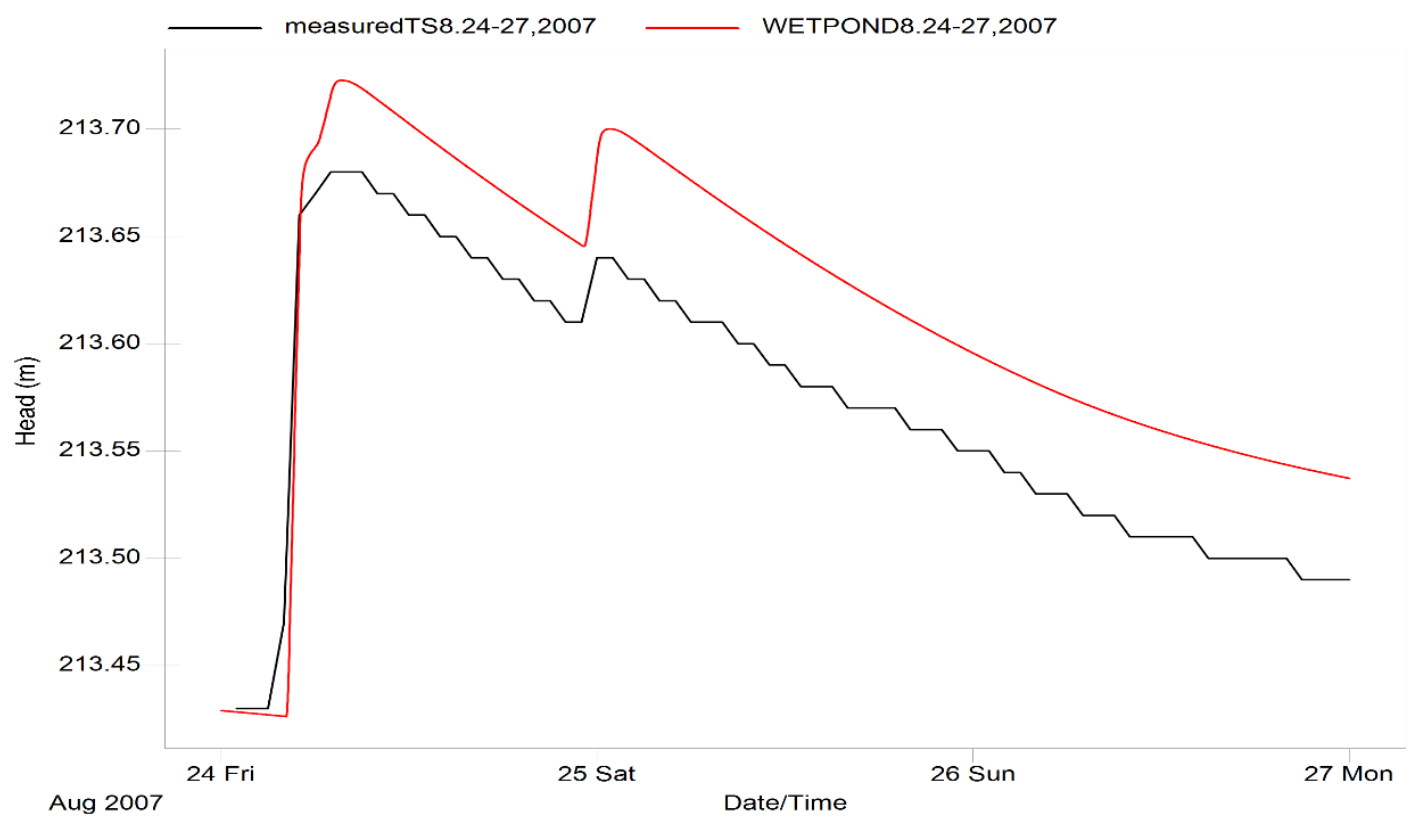

Figure E1 - Pond head comparison for August 24-27, 2007 rainfall event

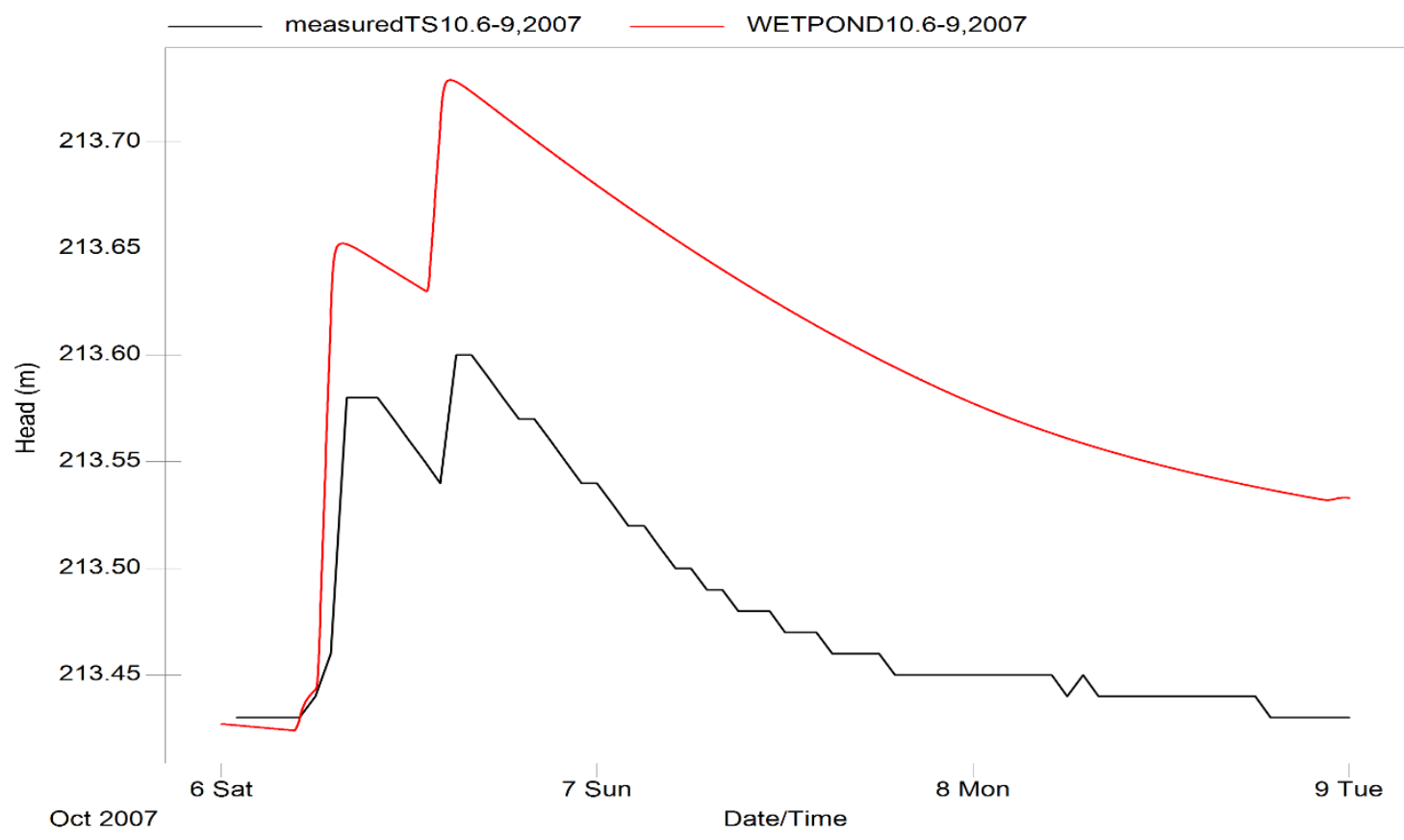

Figure E2 - Pond head comparison for October 6-9, 2007 rainfall event 


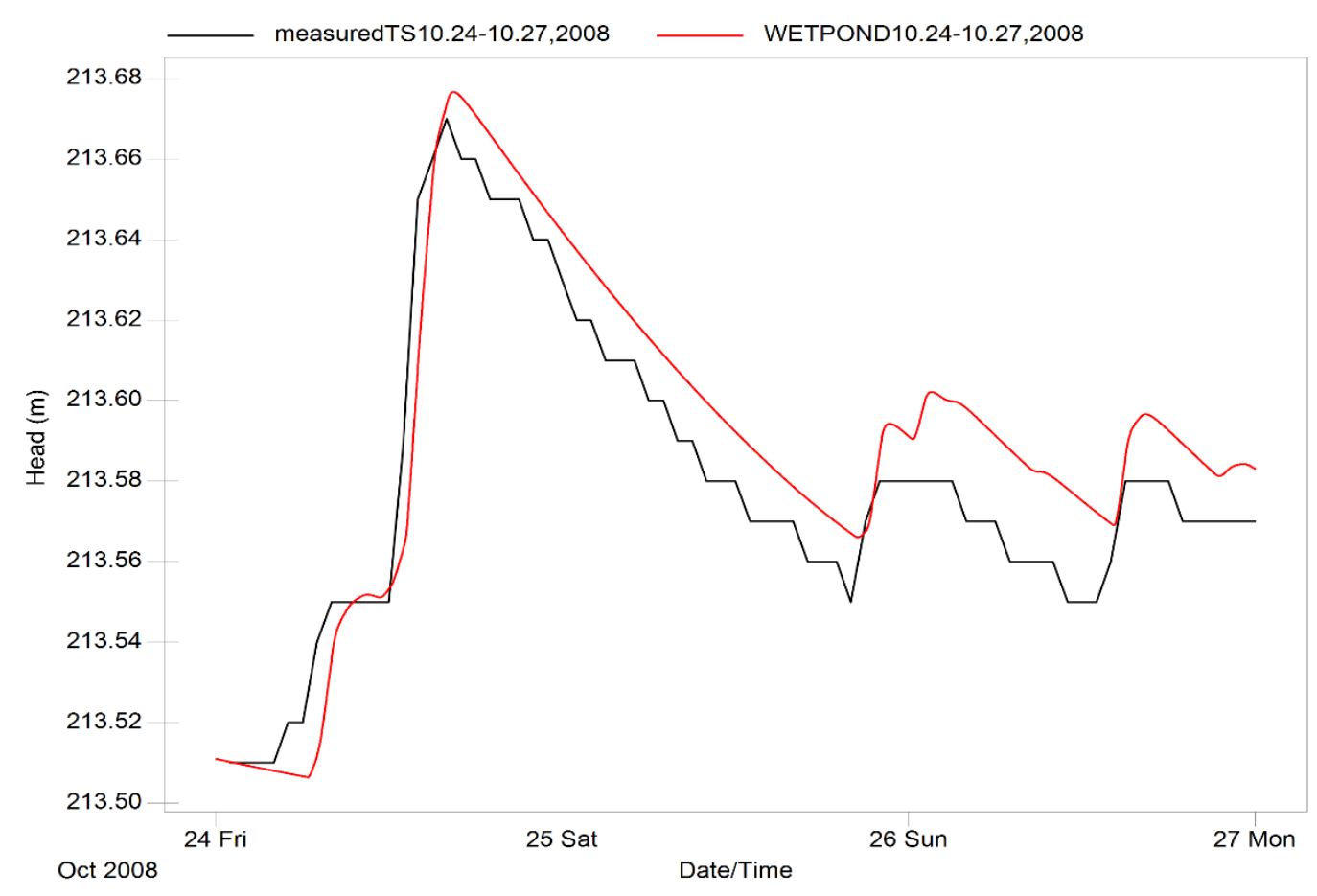

Figure E3 - Pond head comparison for October 24-27, 2008 rainfall event

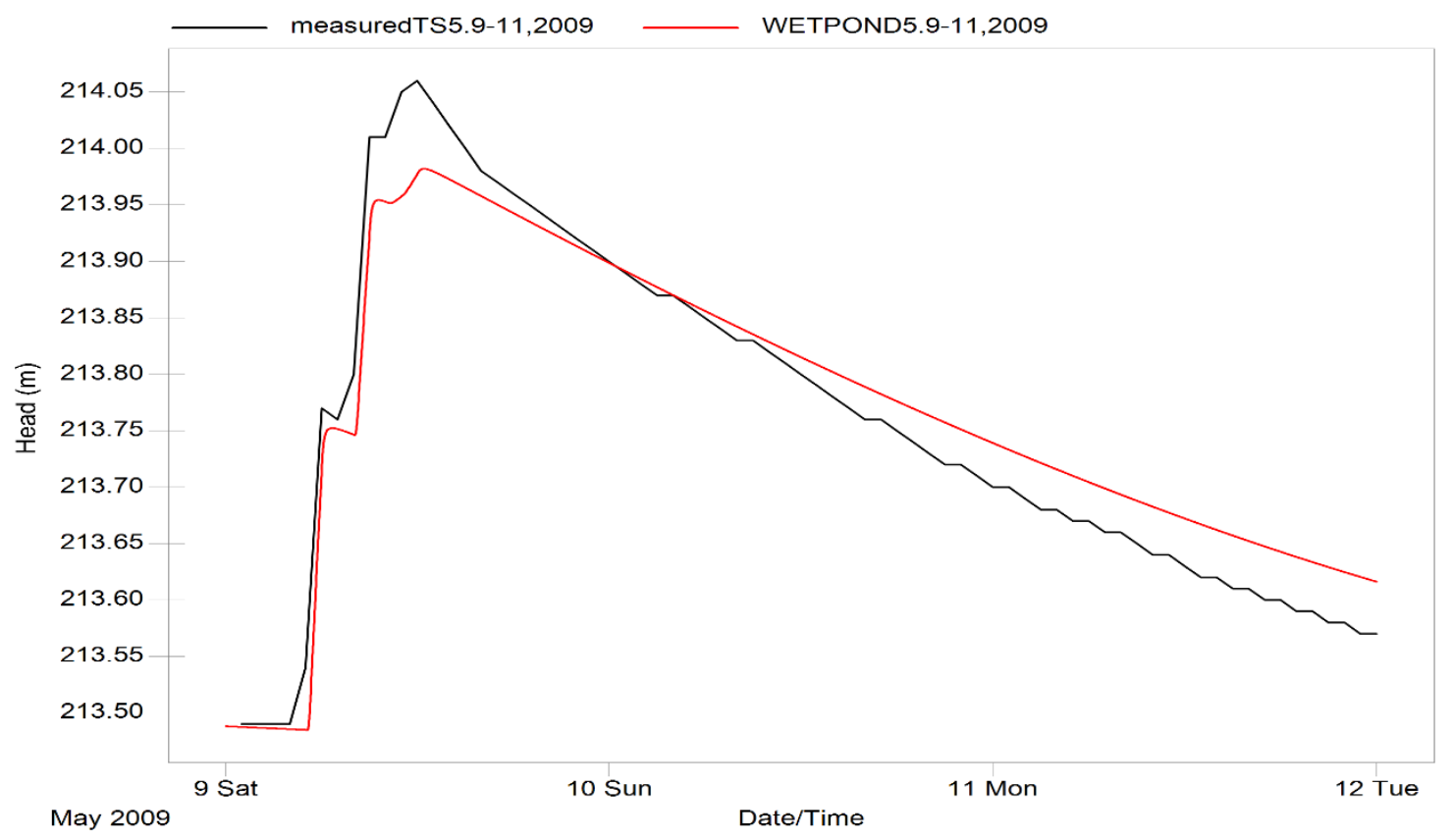

Figure E4 - Pond head comparison for May 9-12, 2009 rainfall event 


\section{Appendix F - Rainfall Data-By Descending Total Record Data}

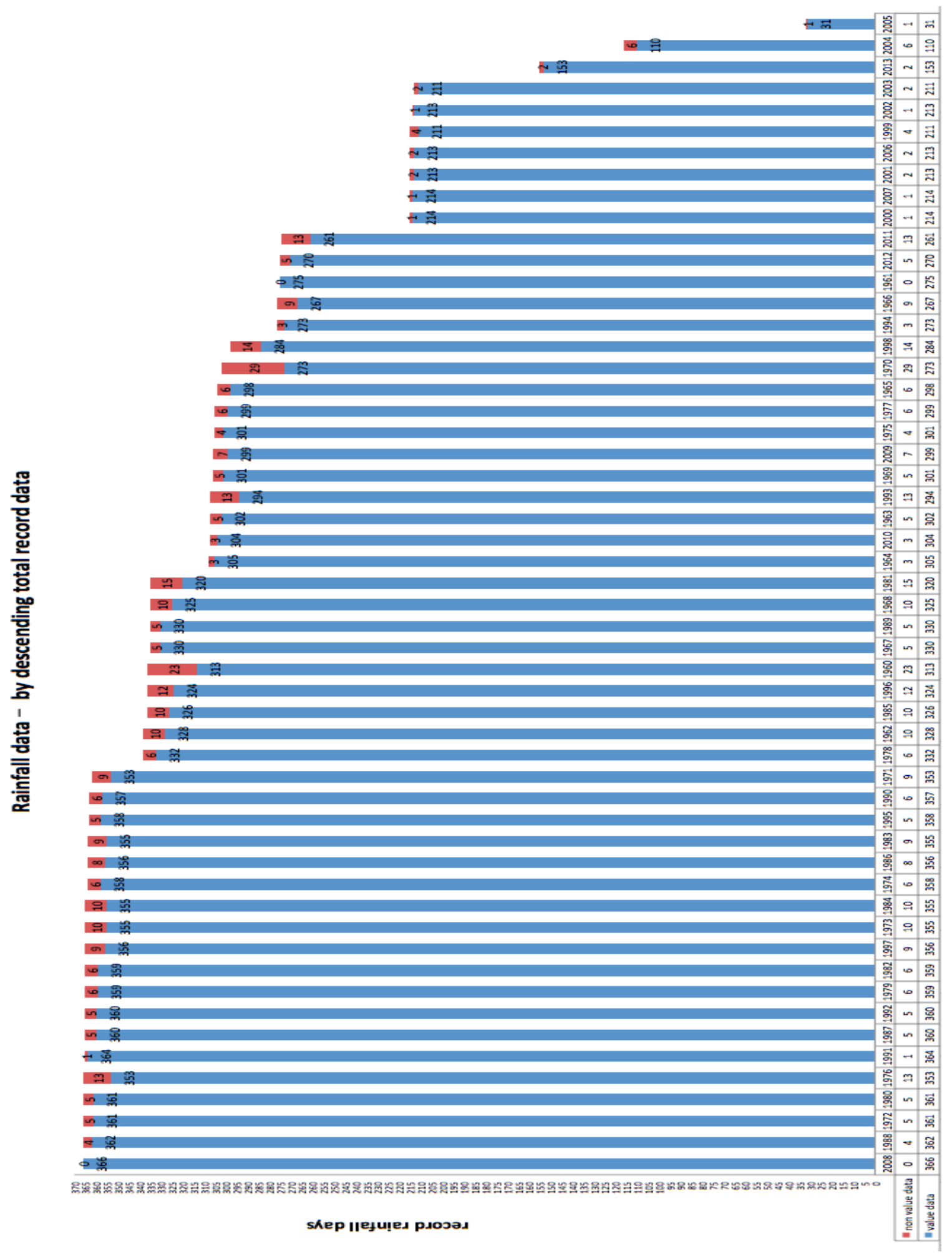

Figure F1 Rainfall data - by descending total record data (Whole year) 


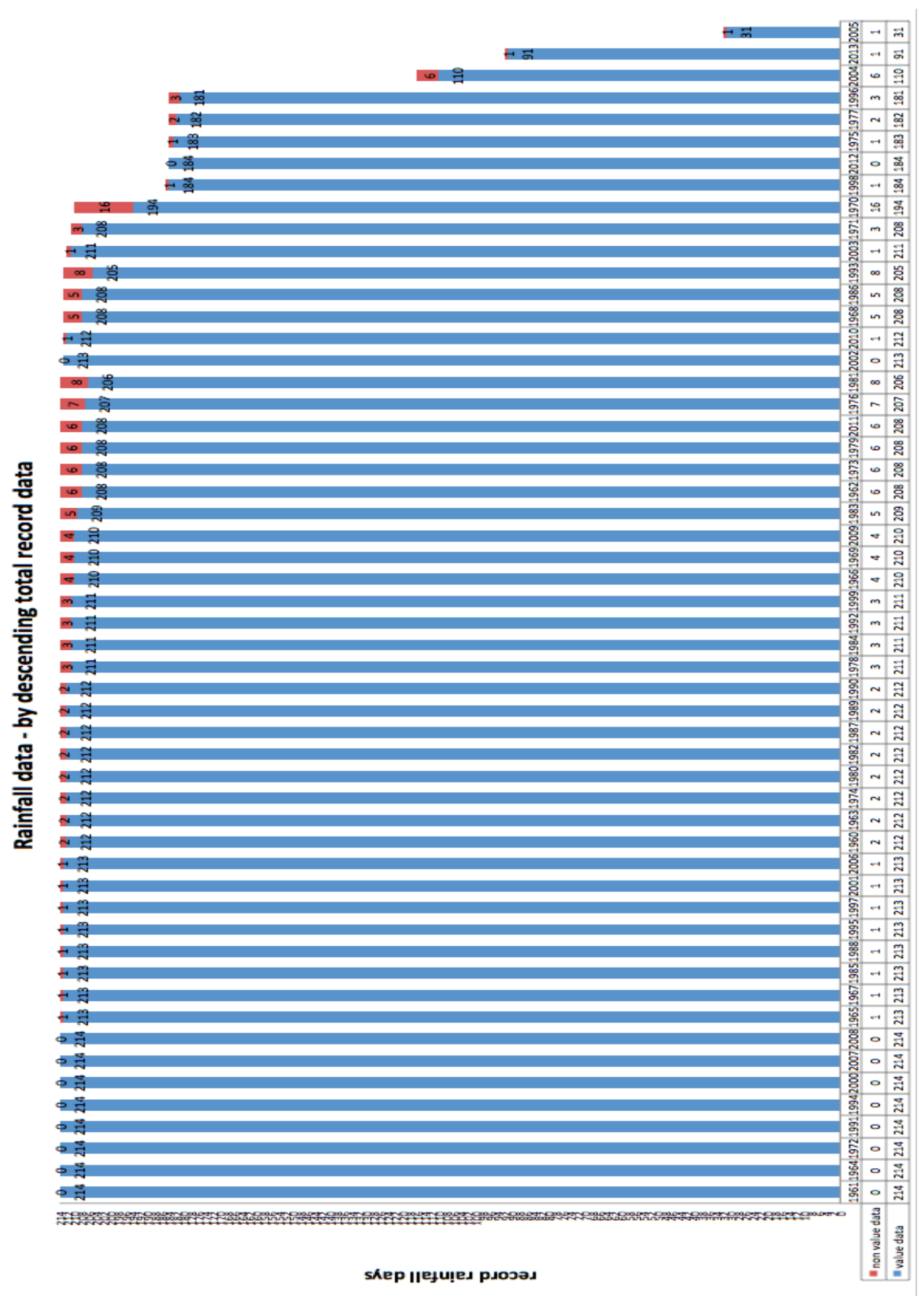

Figure F2 Rainfall data - by descending total record data (April- October) 


\section{Appendix G - System Sensitivity Analysis - WetPond Head}

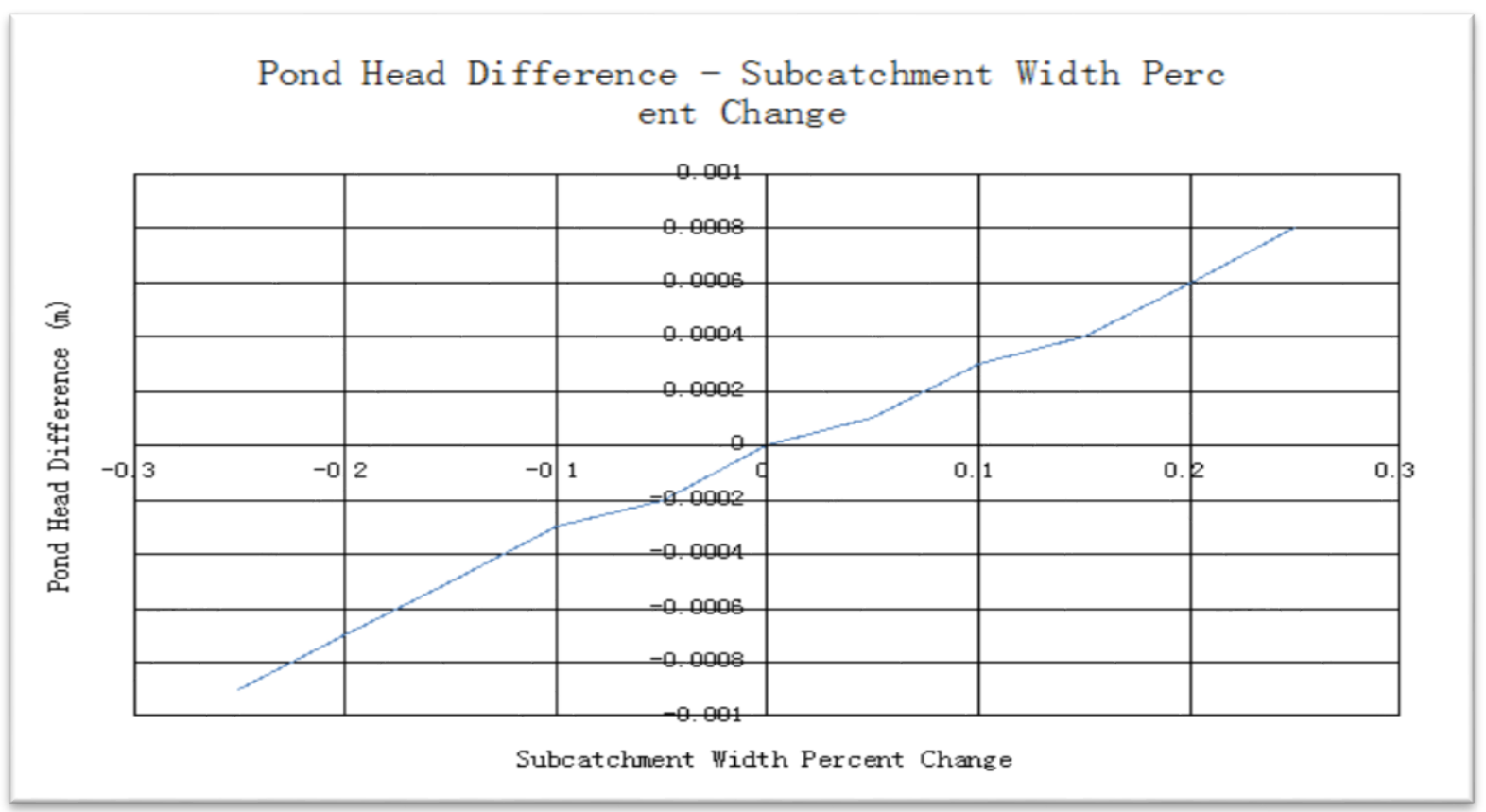

G1 Pond Head Percent Change - Subcatchment Width Percent Change

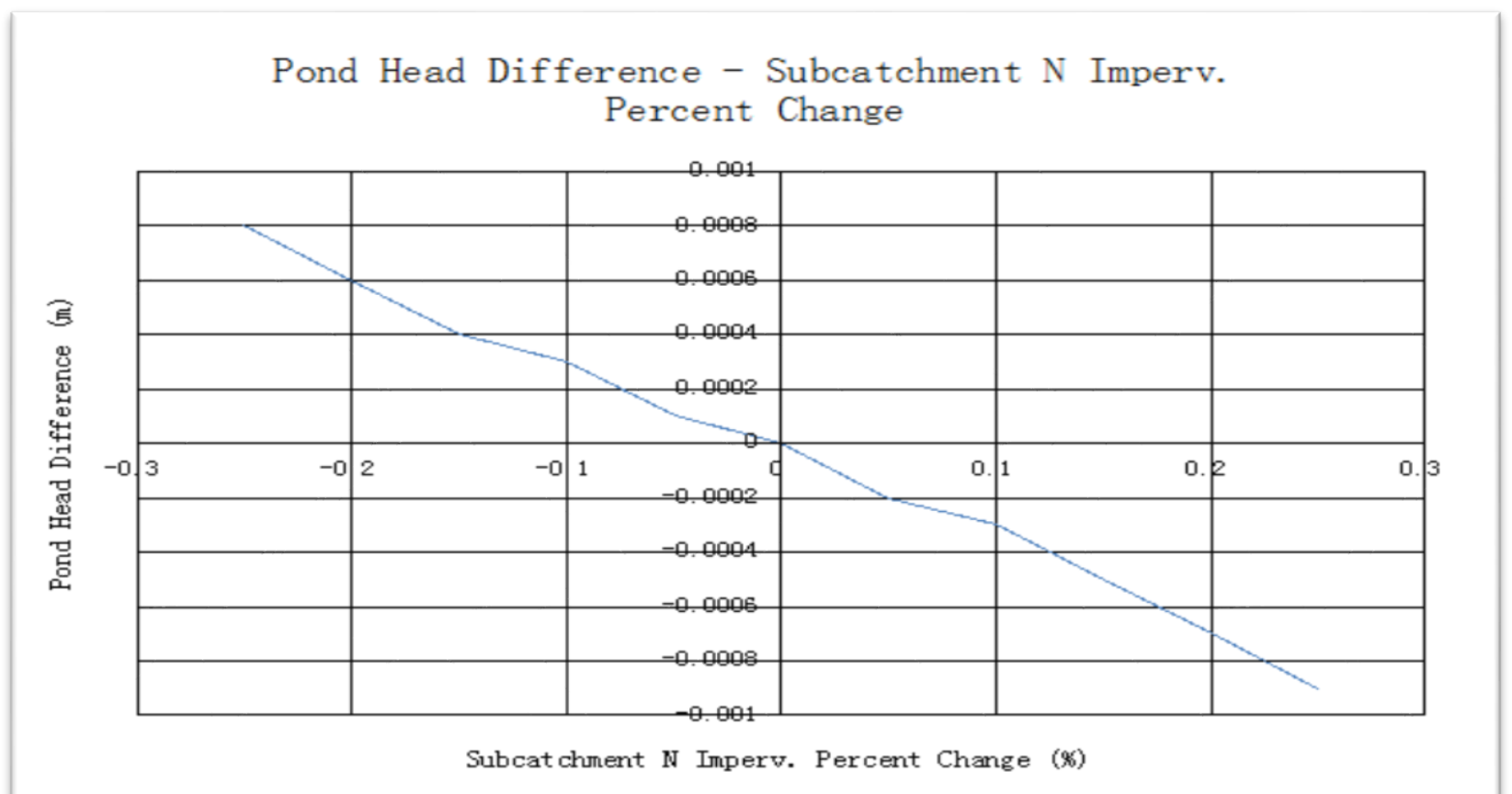

G2 Pond Head Percent Change - Subacatchment N Imperv. Percent Change 


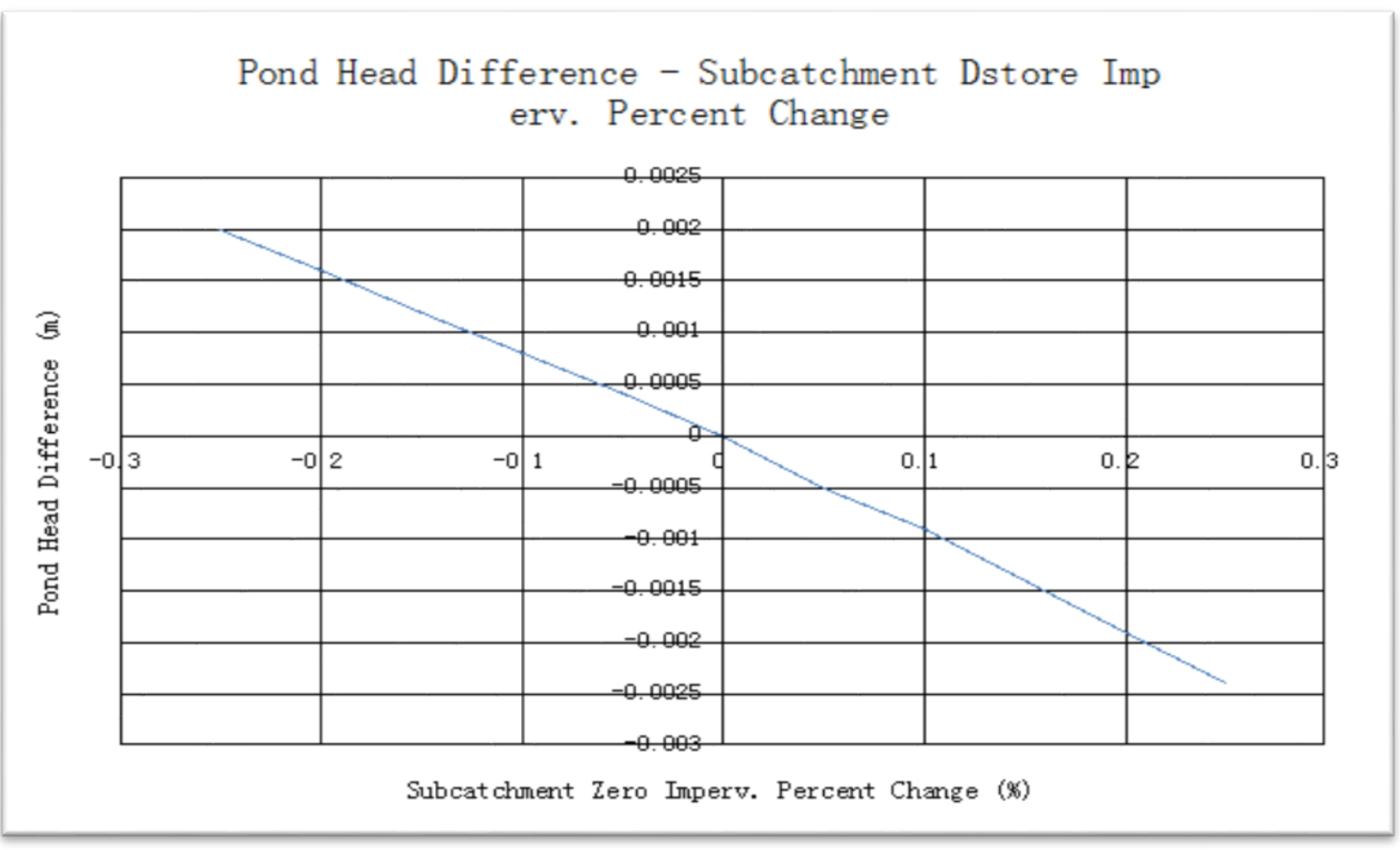

G3 Pond Head Percent Change - SubacatchmentDstoreImperv. Percent Change

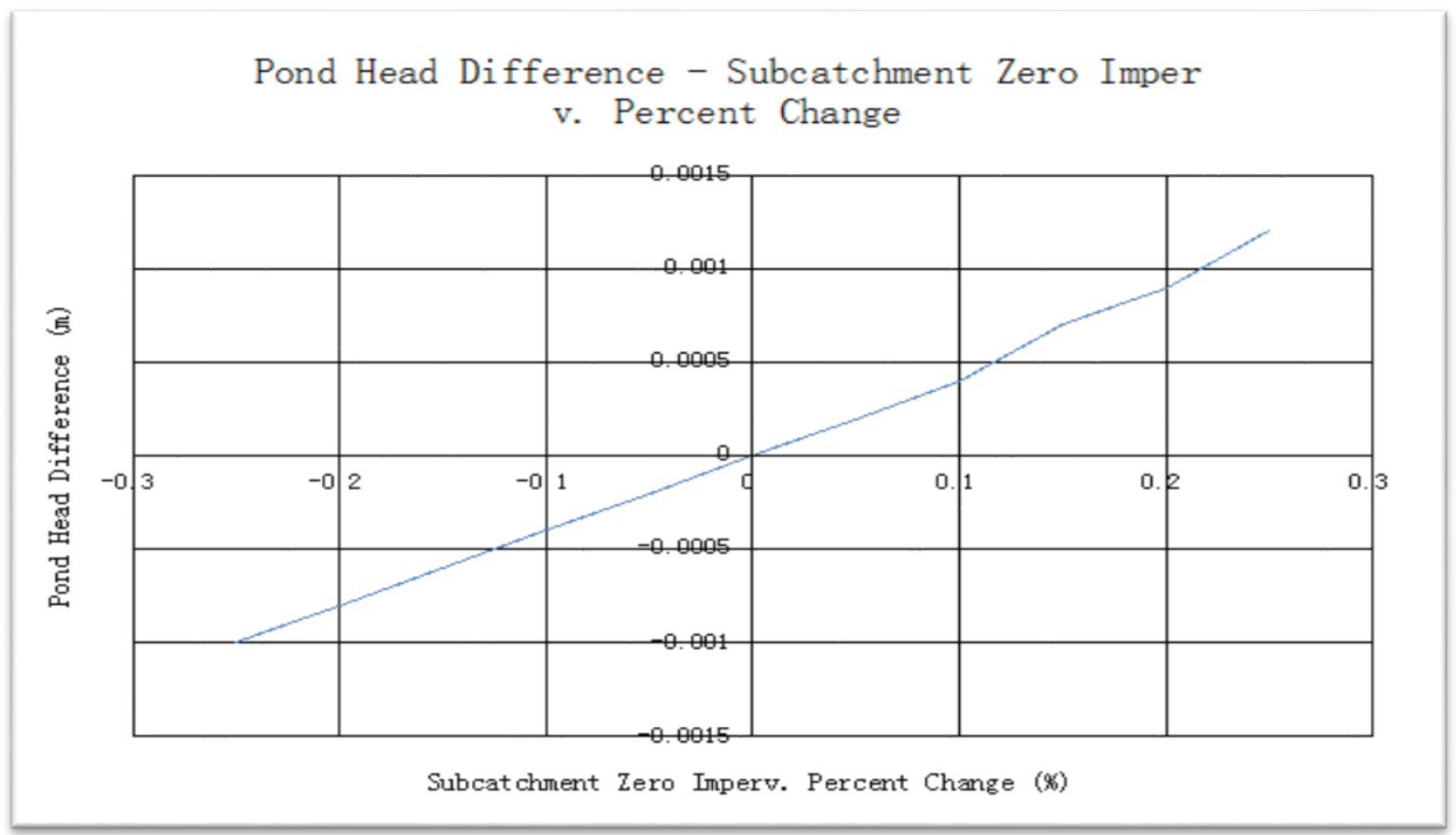

G4 Pond Head Percent Change - Subacatchment Zero Imperv. Percent Change 


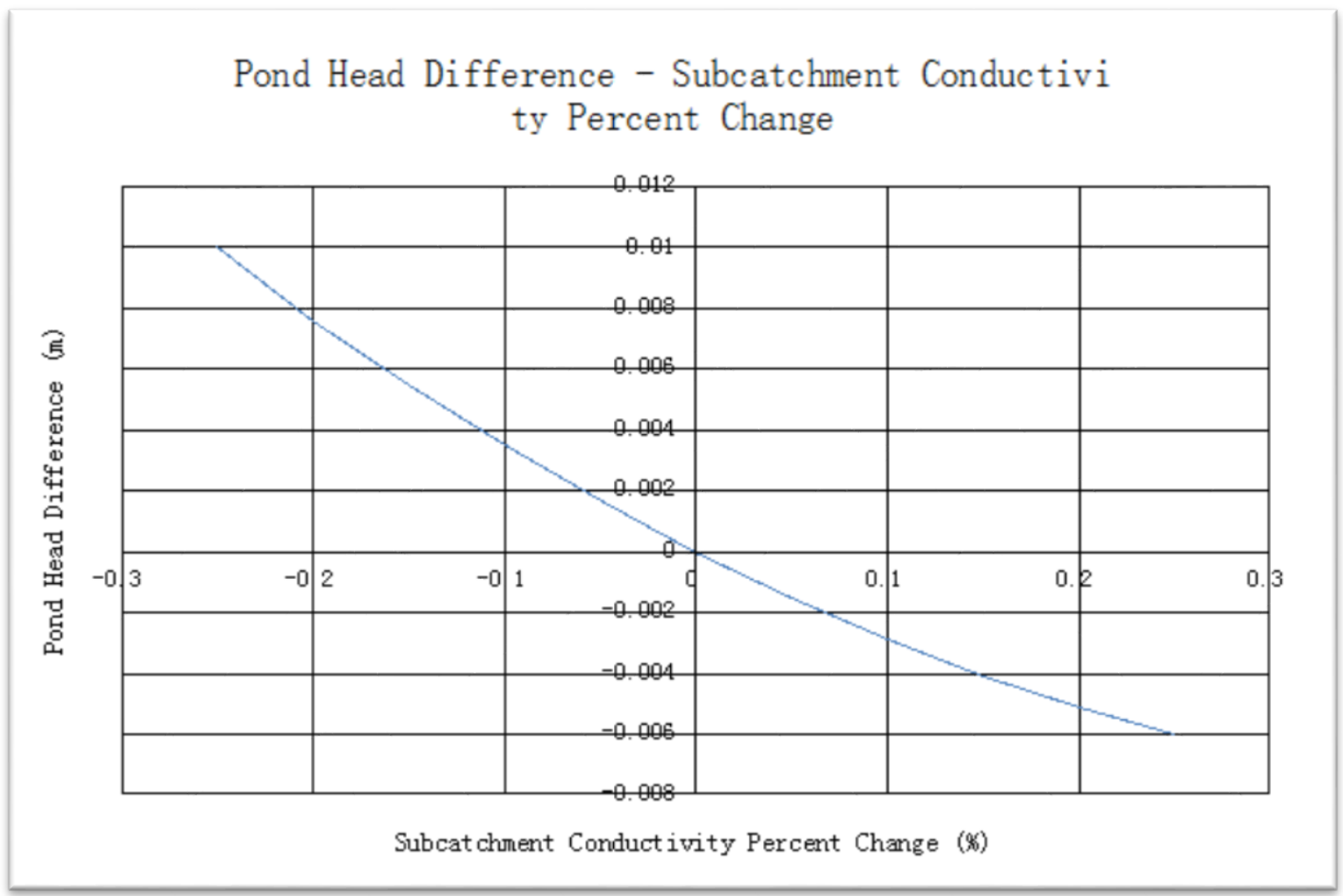

G5 Pond Head Percent Change - SubacatchmentSoil Conductivity Percent Change

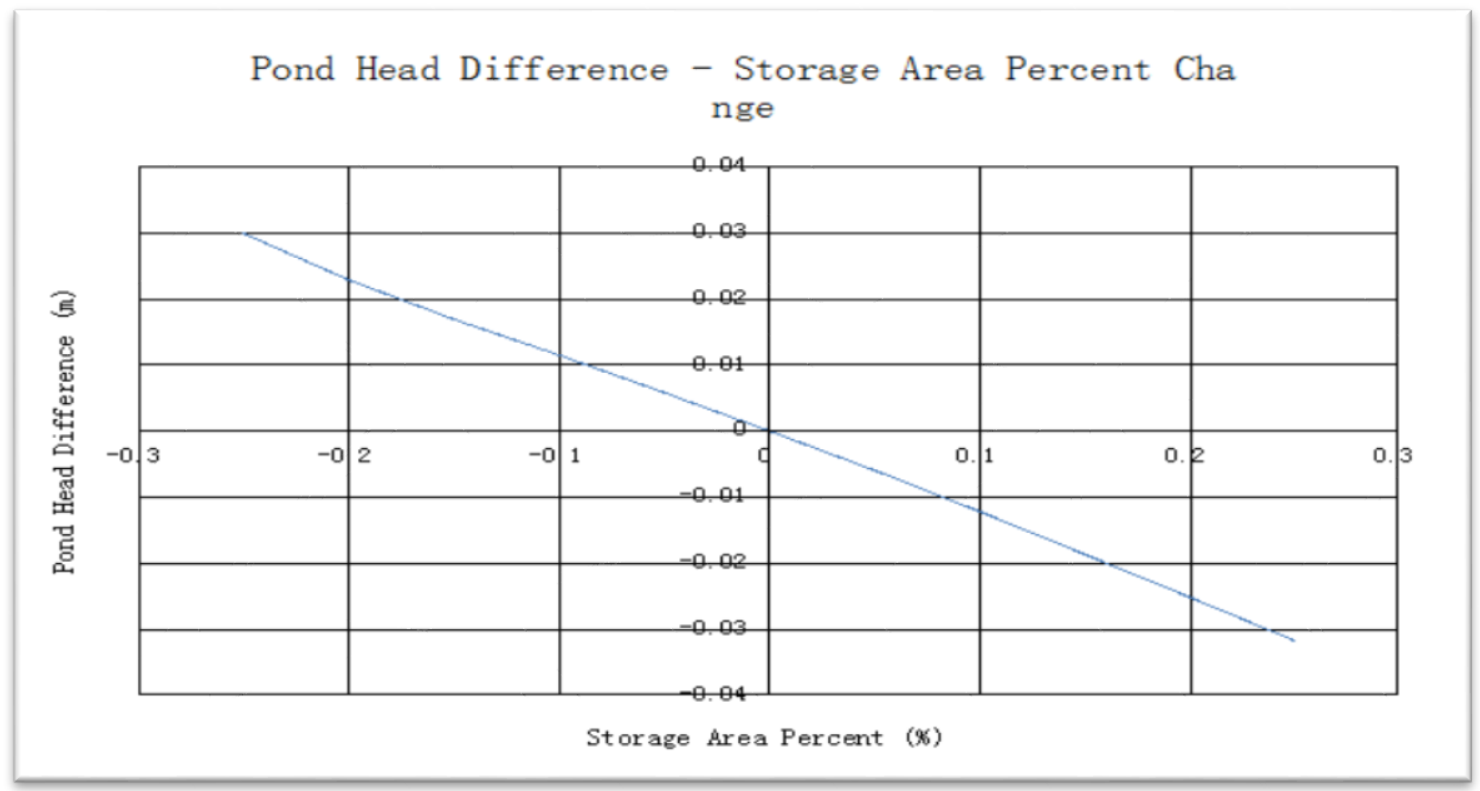

G6 Pond Head Percent Change - Trench Area Percent Change 


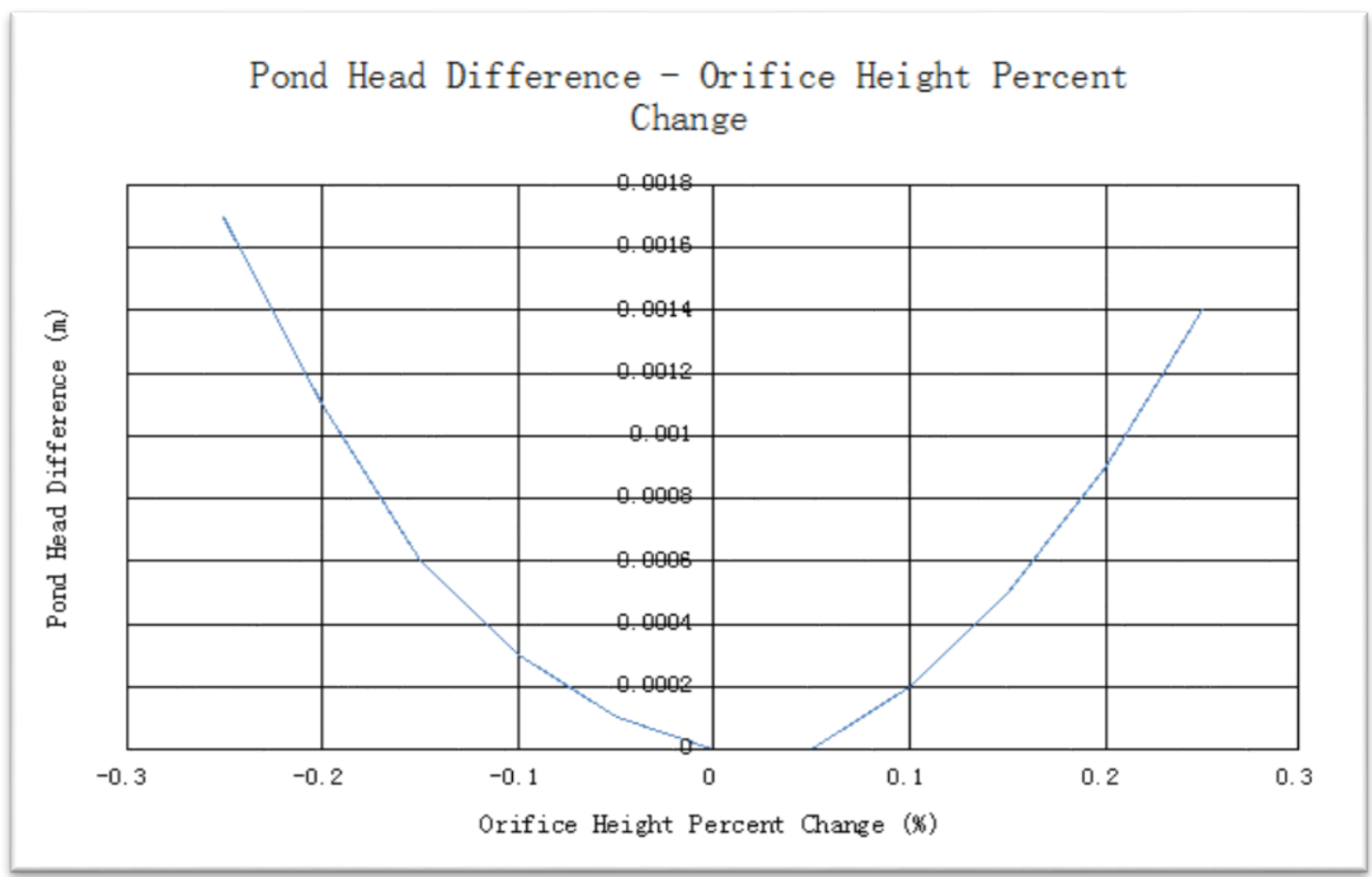

G7 Pond Head Percent Change - Orifice Height Percent Change

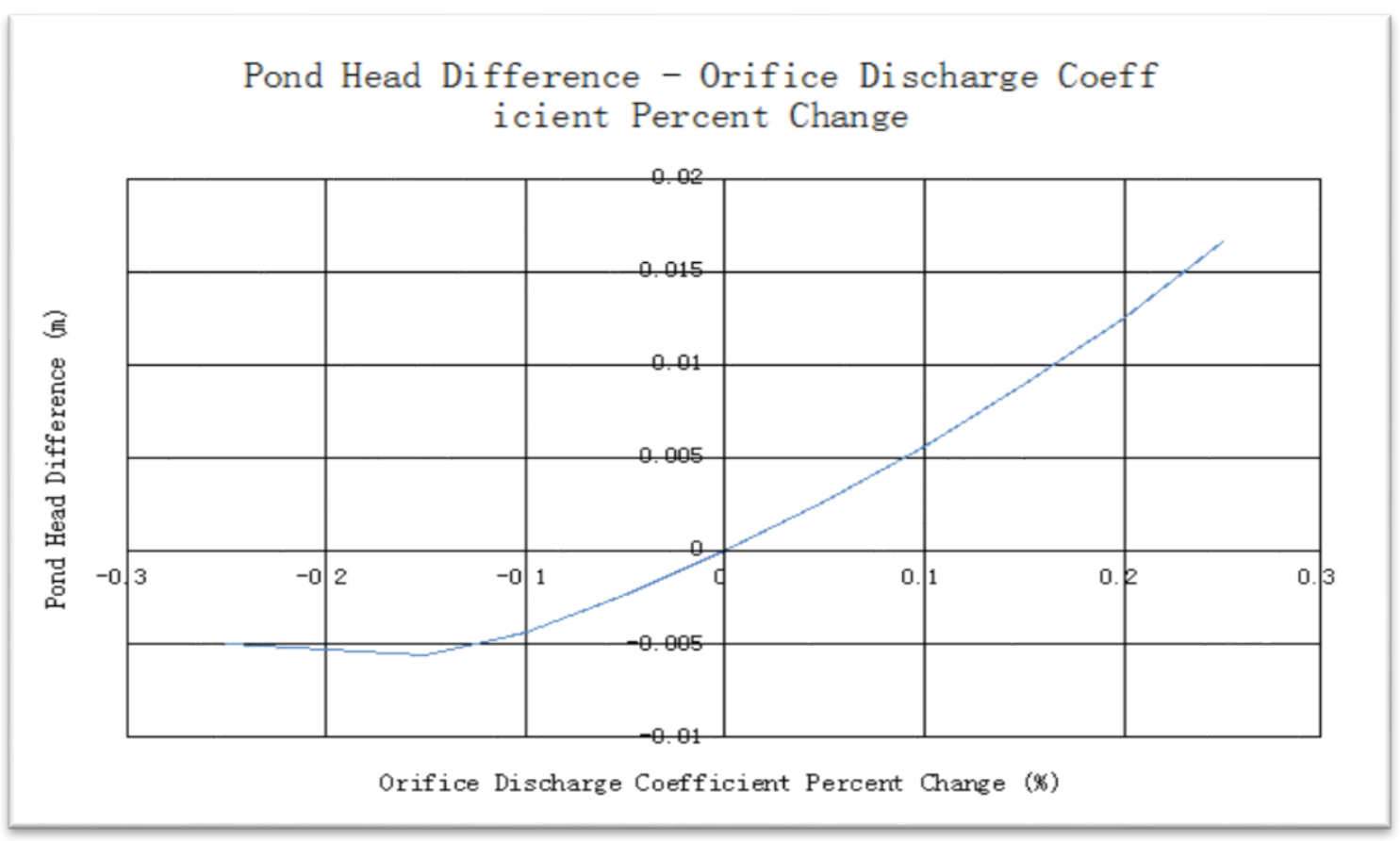

G8 Pond Head Percent Change - Orifice Discharge Coefficient Percent Change 


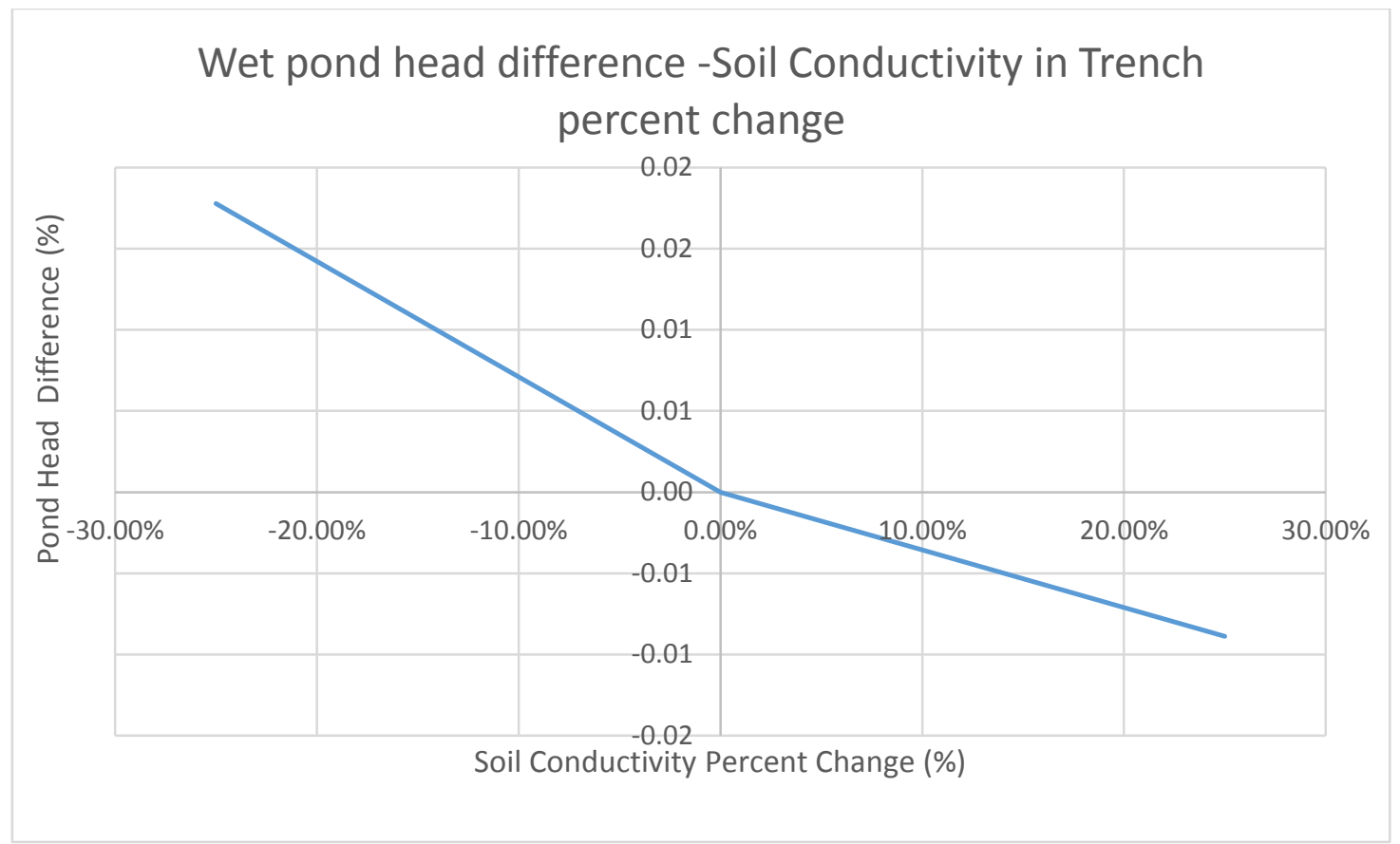

G9 Pond Head Percent Change - Soil Conductivity in Trench Percent Change 


\section{Appendix H - System Sensitivity Analysis - Wet Pond Inflow and}

\section{Outflow}

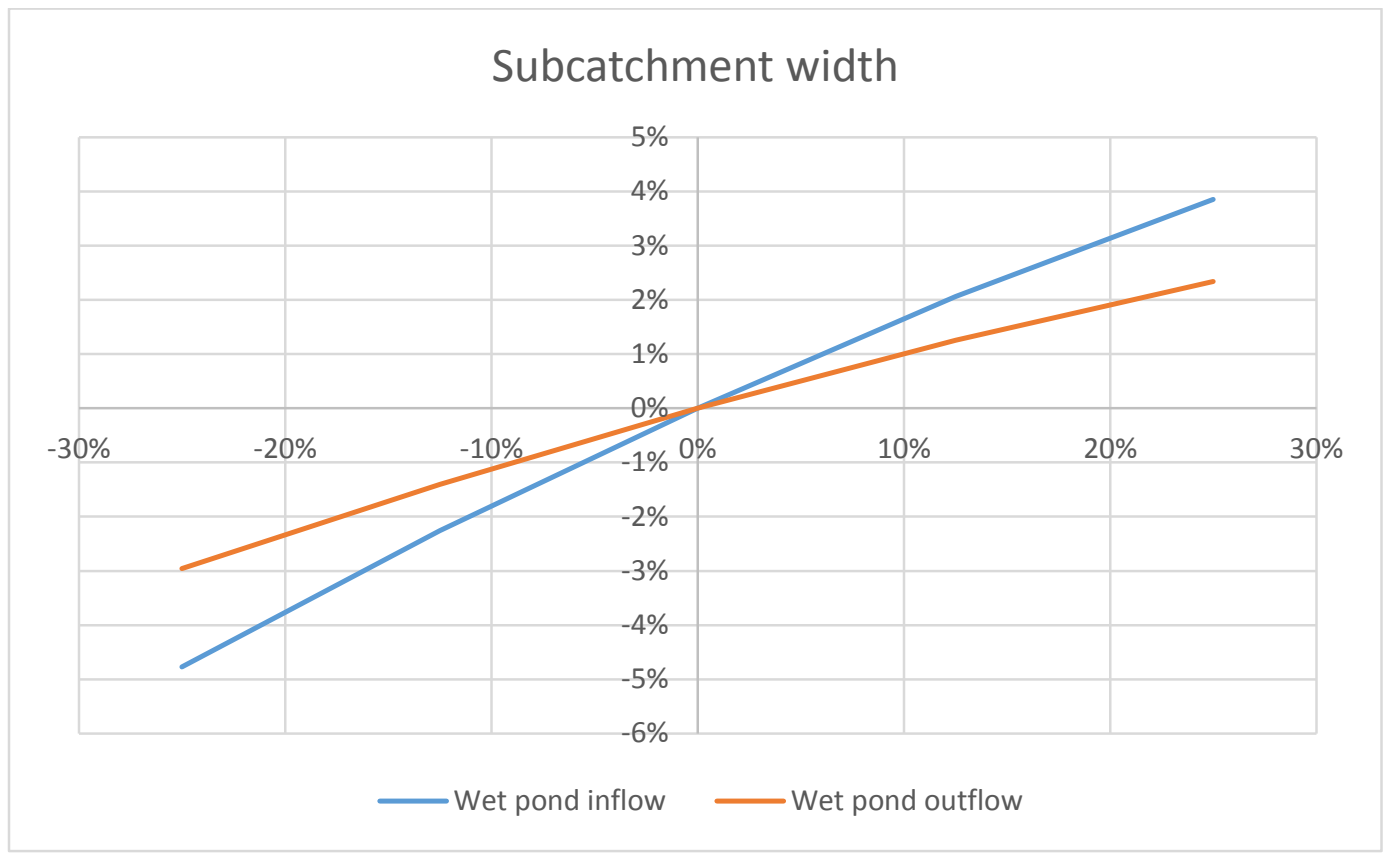

H1 Wet pond inflow and outflow vs subcatchment width

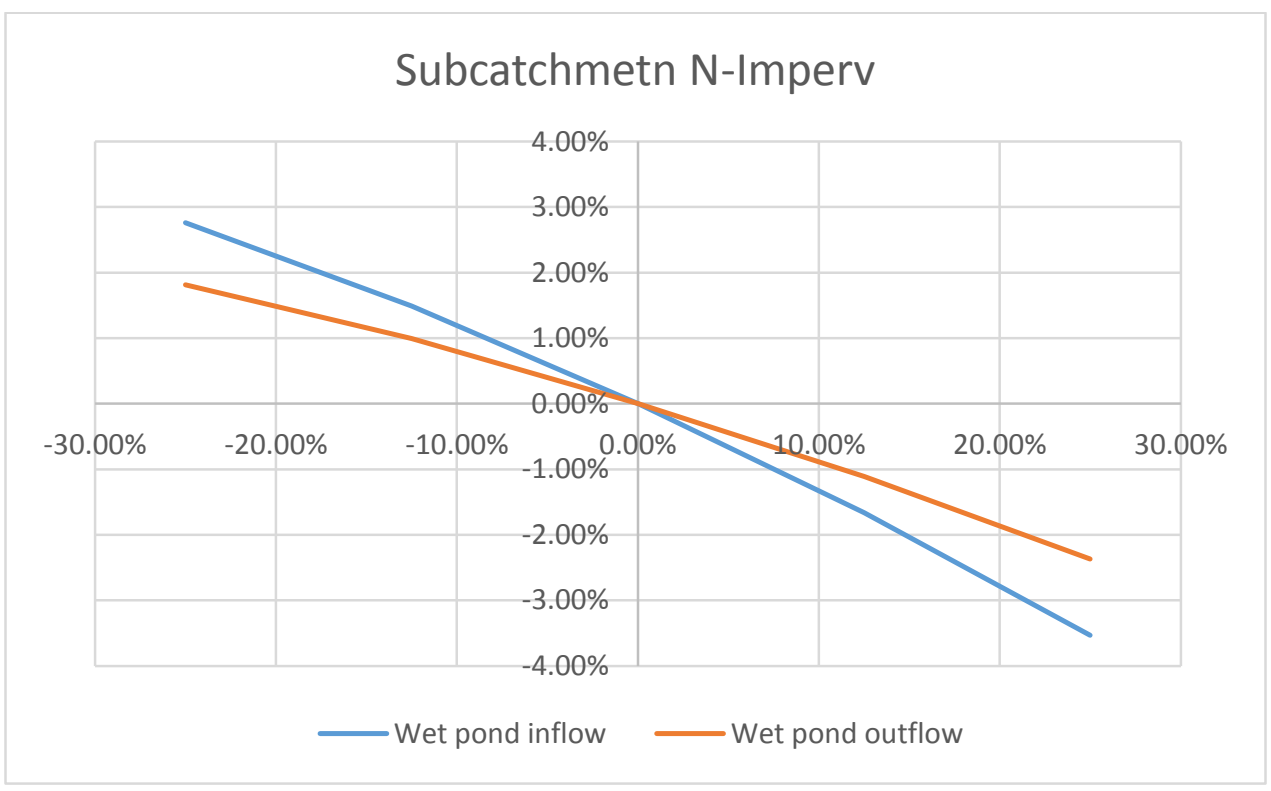

$\mathrm{H} 2$ Wet pond inflow and outflow vs subcatchment N-Imperv 


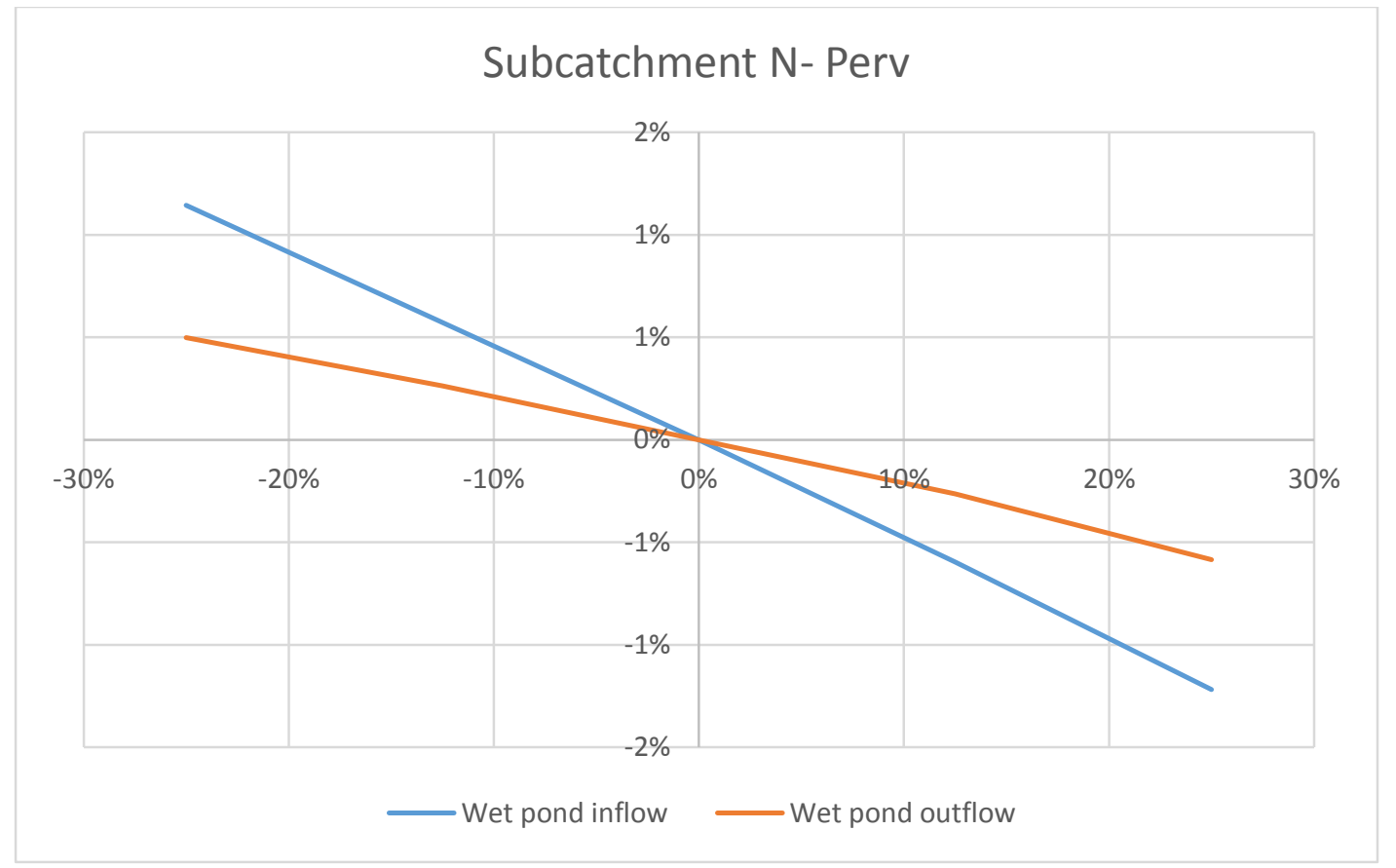

H3 Wet pond inflow and outflow vs subcatchment N-Perv

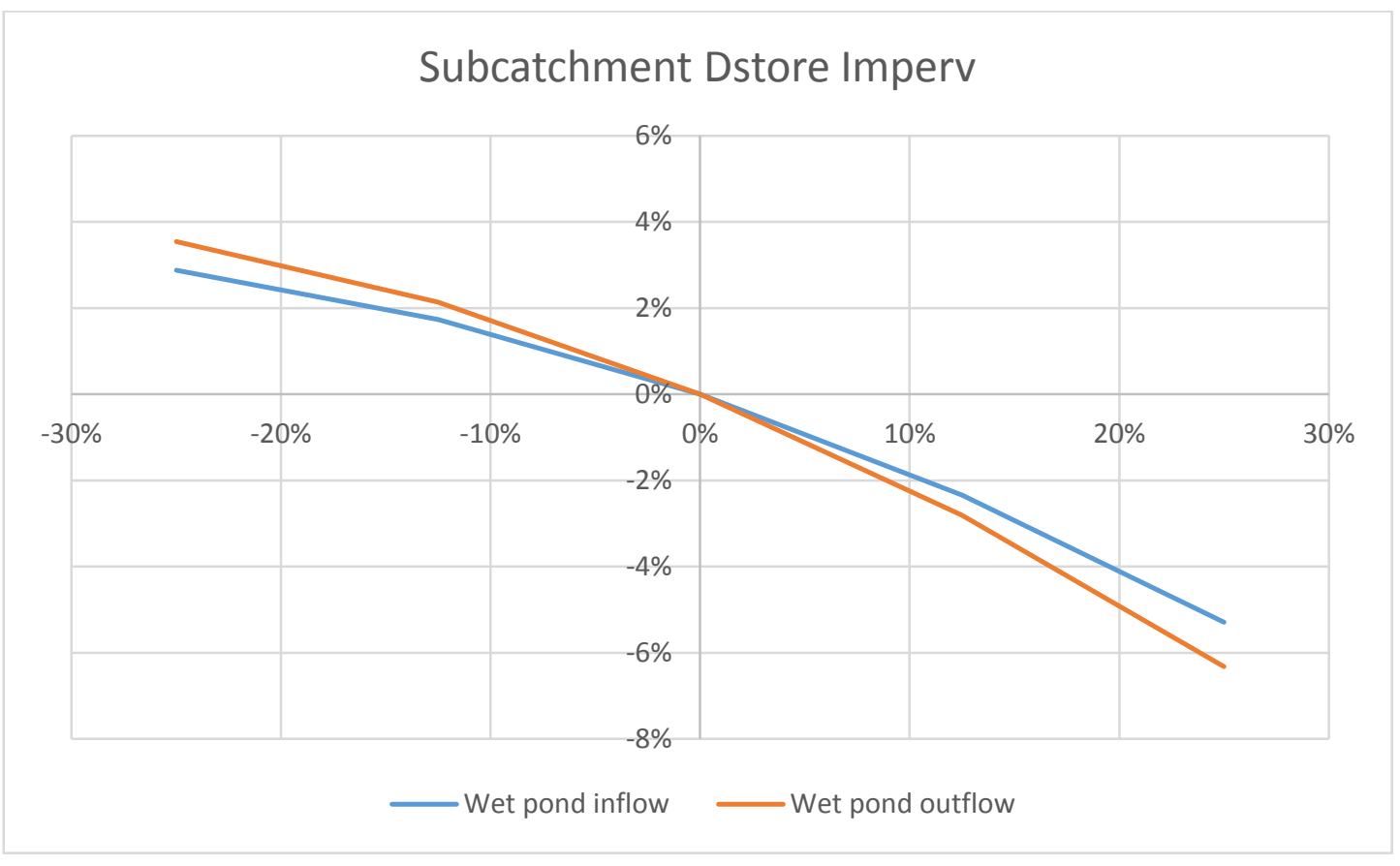

H4Wet pond inflow and outflow vs subcatchmentDstoreImperv 


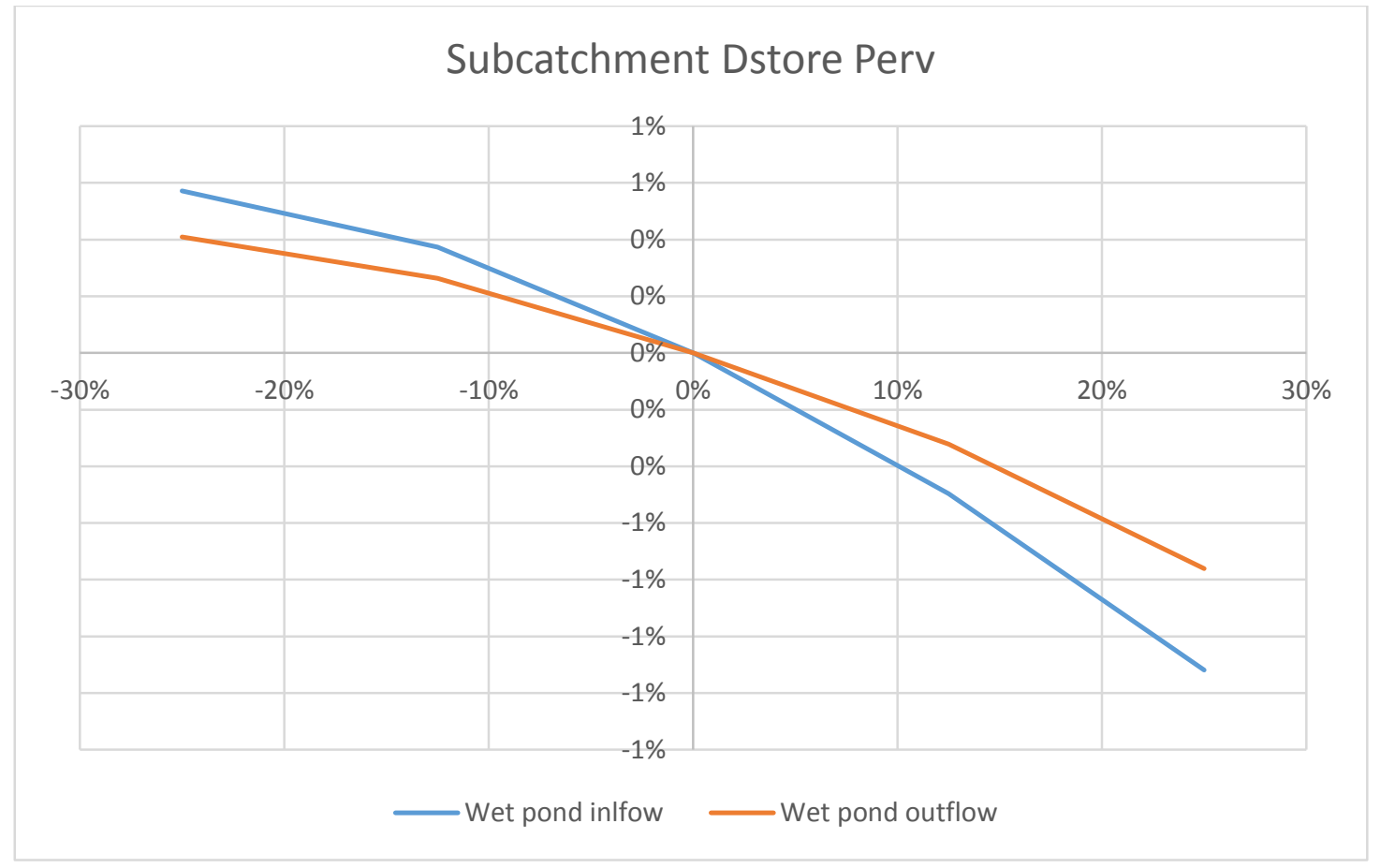

H5Wet pond inflow and outflow vs subcatchmentDstorePerv

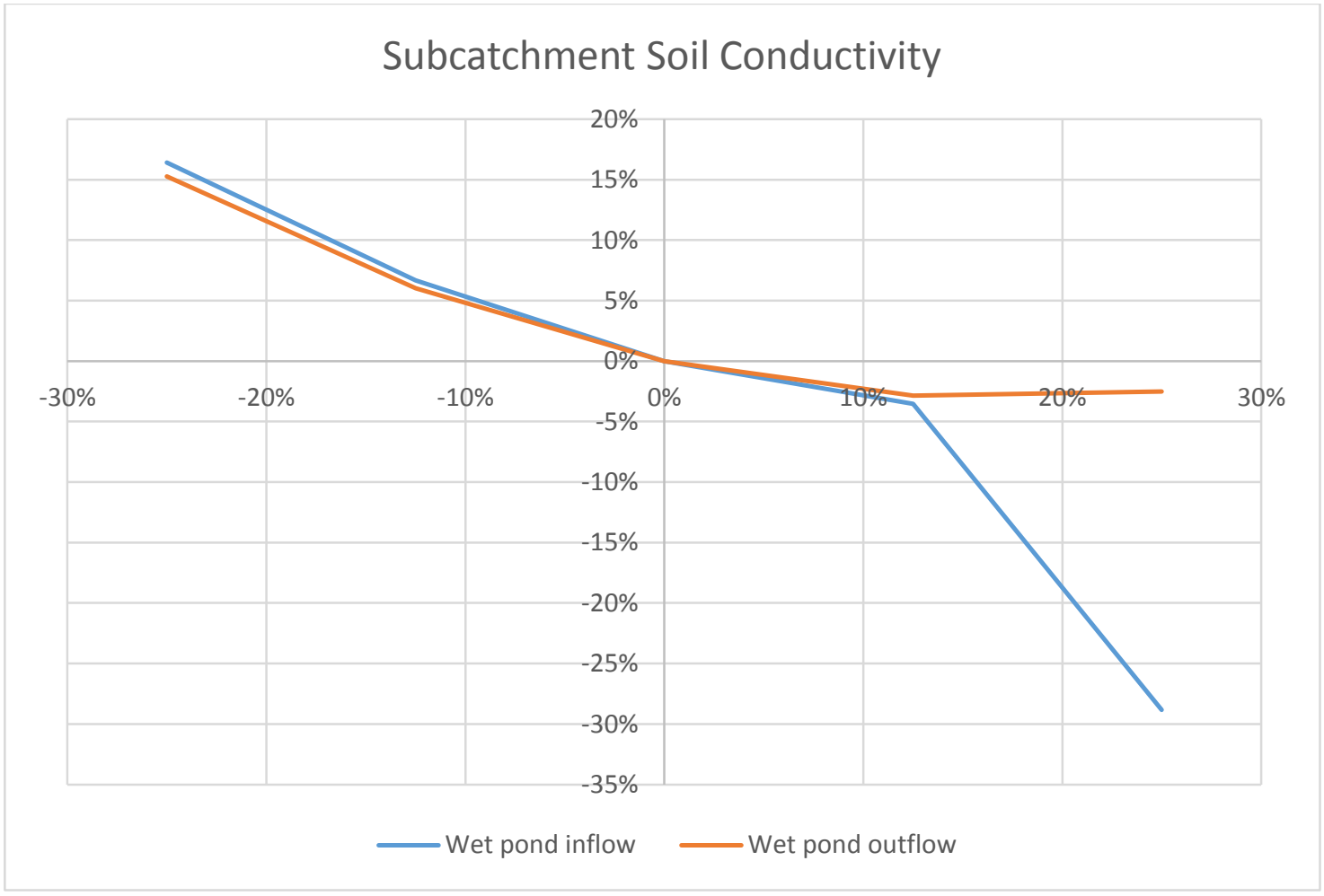

H6Wet pond inflow and outflow vs subcatchment soil conductivity 


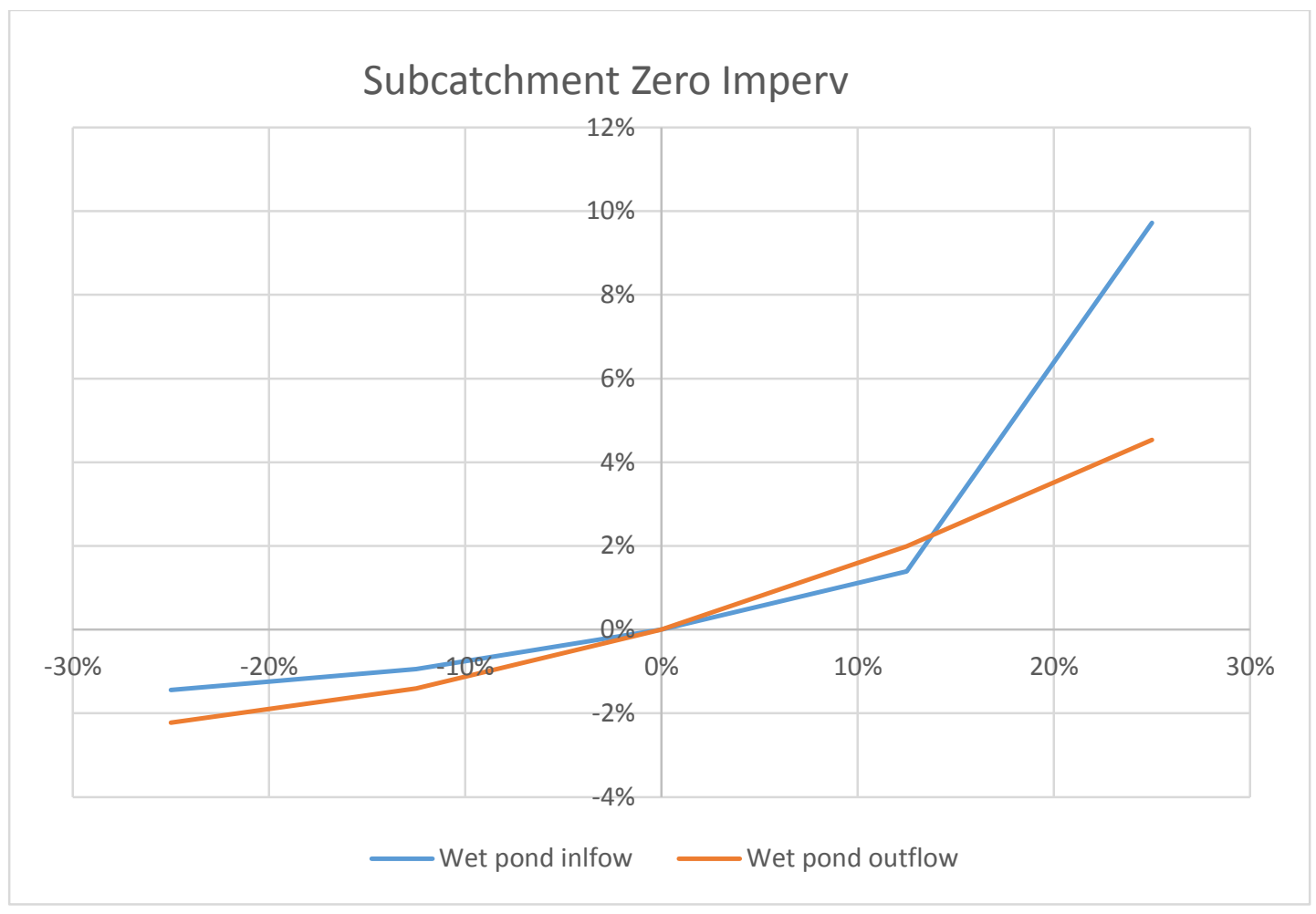

H7 Wet pond inflow and outflow vs subcatchment zero imperv

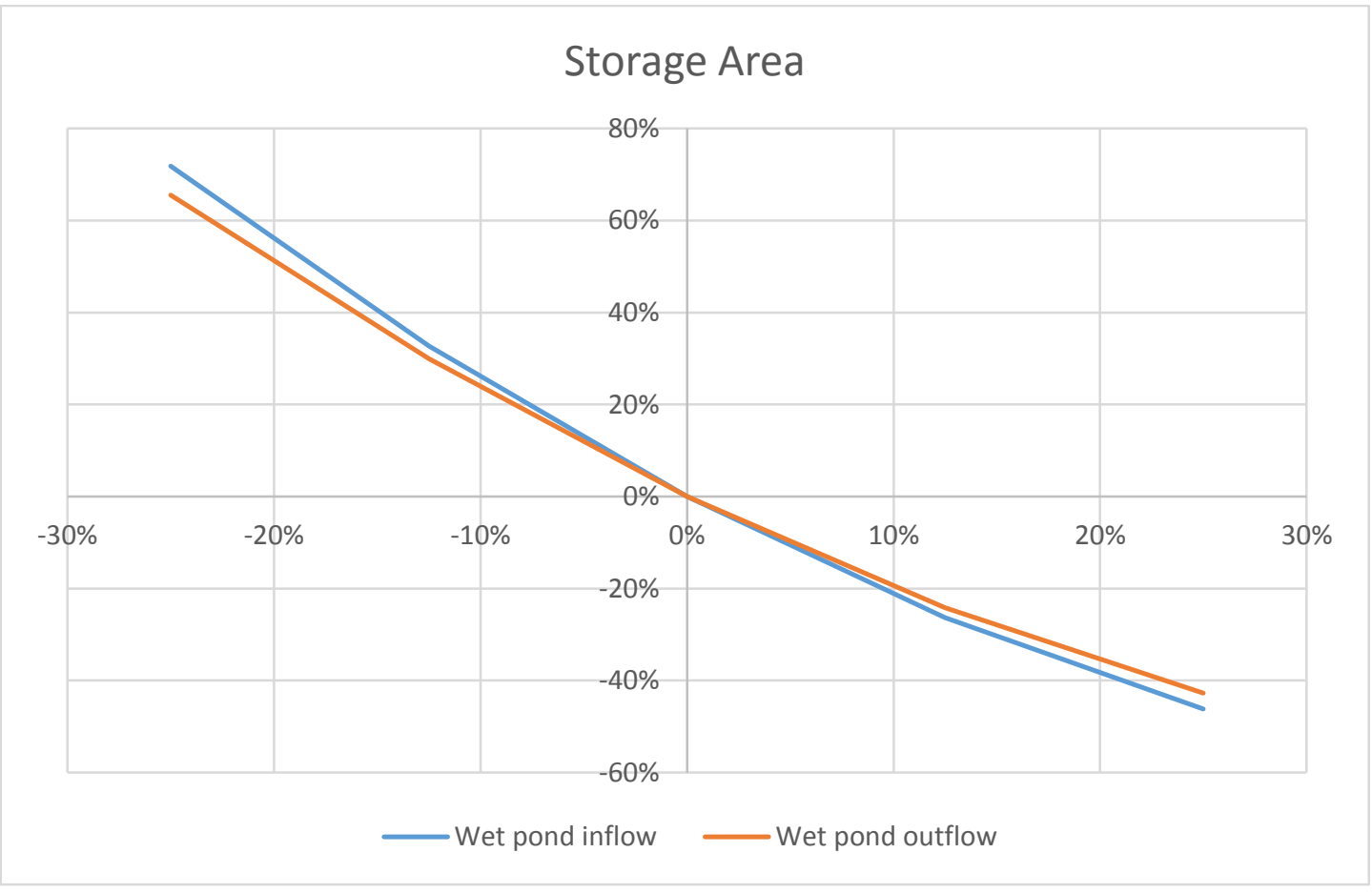

H8Wet pond inflow and outflow vs storage area 


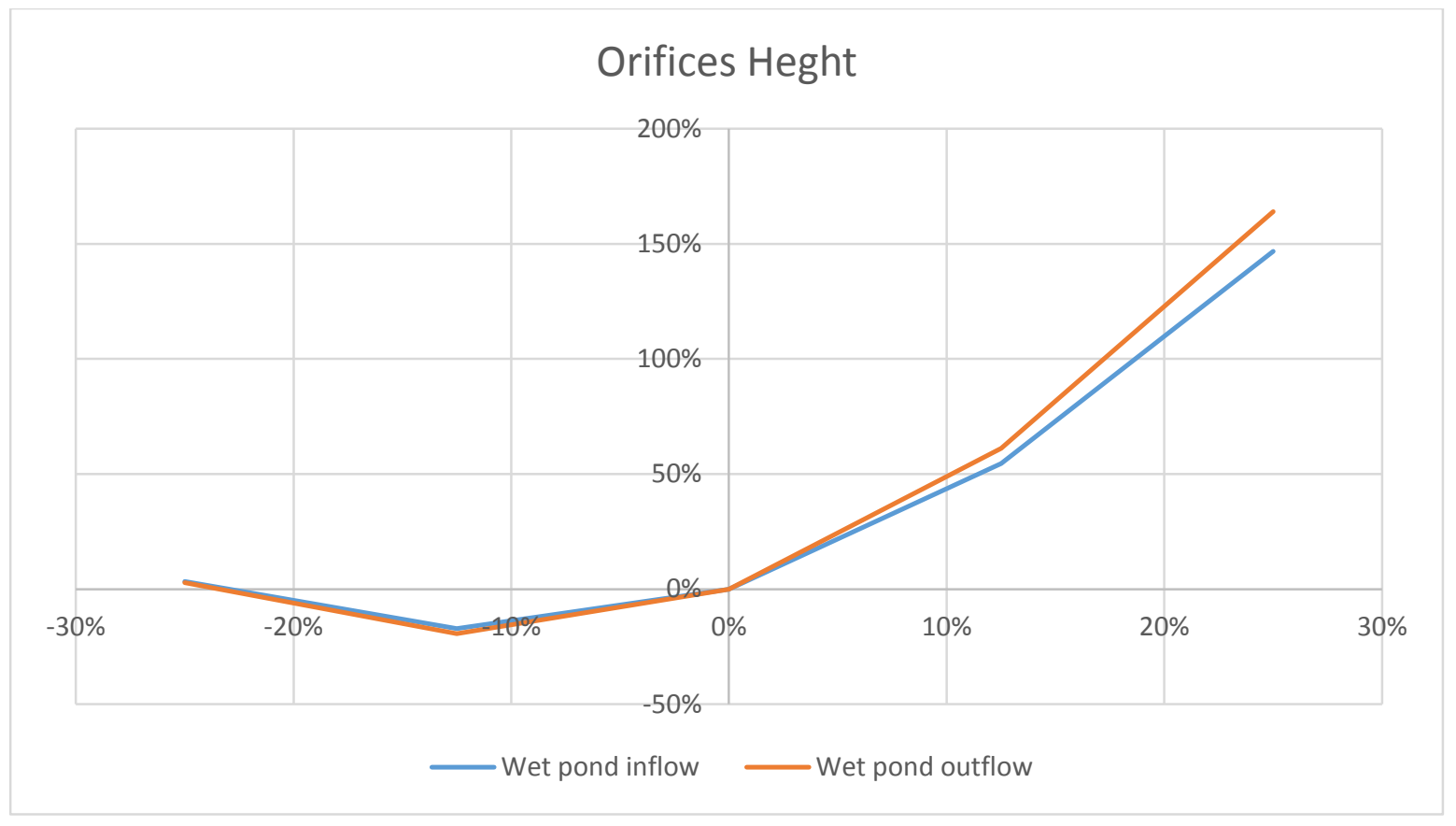

H9 Wet pond inflow and outflow vs orifices height

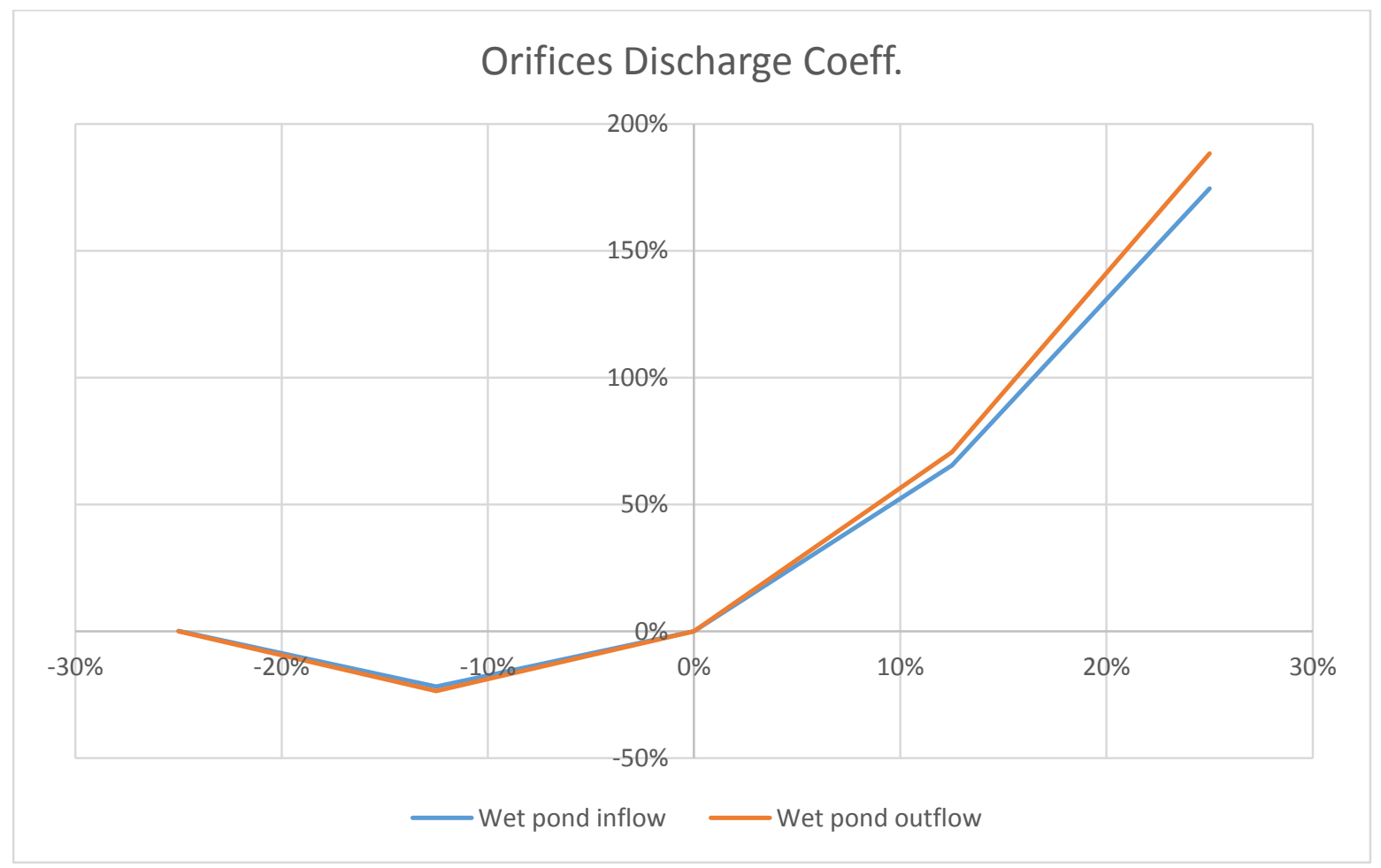

H10 Wet pond inflow and outflow vs orifices discharge coefficient. 


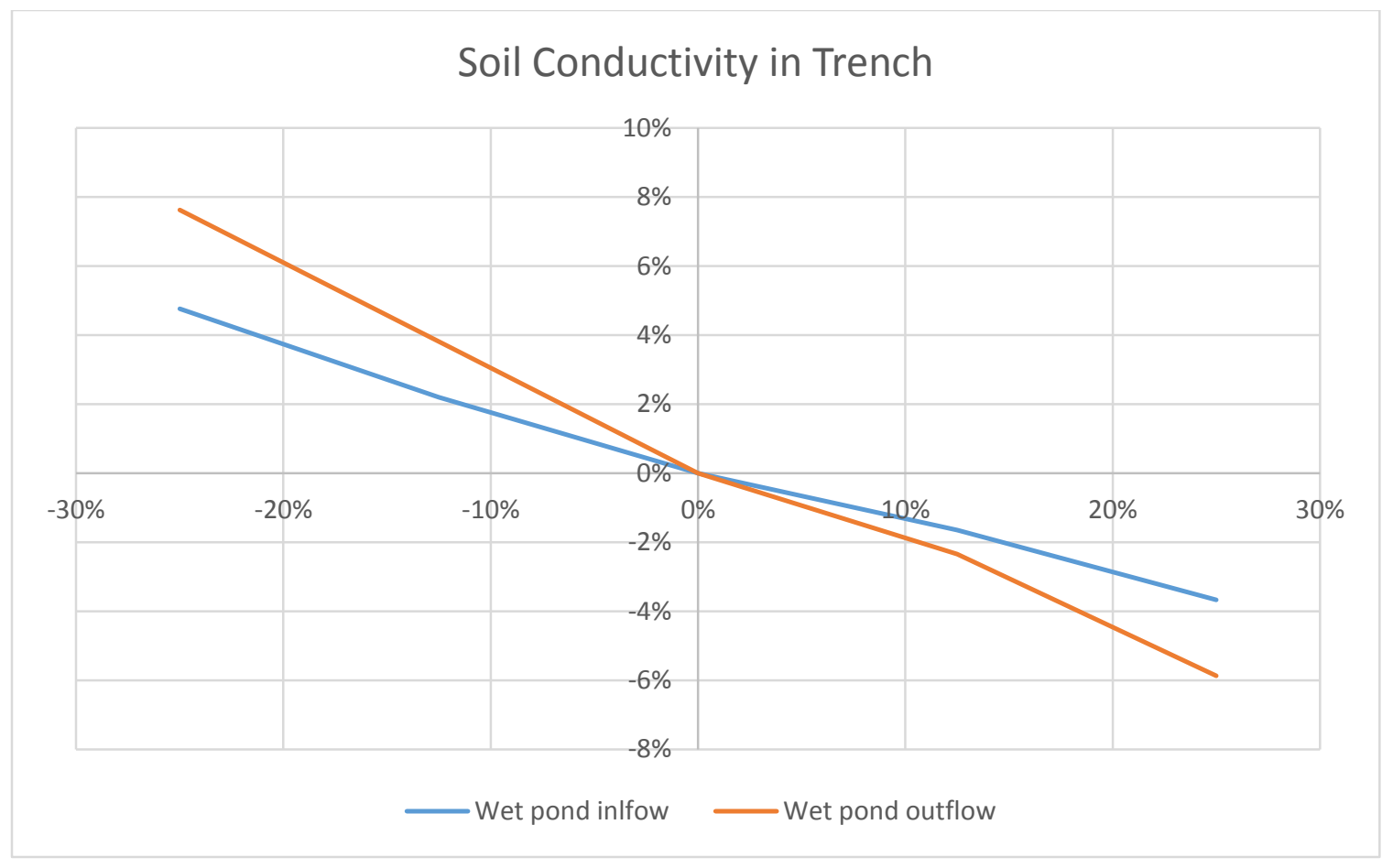

H11Wet pond inflow and outflow vs soil conductivity in Trench 